\title{
Conservation, biodiversity and governance of semi-natural grasslands in Southern Transylvania (Romania)
}

\author{
Dissertation \\ for the award of the degree \\ "Doctor of Philosophy" Ph.D., \\ Division of Mathematics and Natural Sciences \\ of the Georg-August University of Göttingen \\ within the doctoral program Biology \\ of the Georg-August University School of Science (GAUSS) \\ submitted by \\ Laura Sutcliffe \\ from \\ Great Yarmouth (UK)
}

Göttingen, November 2013 


\section{Thesis Committee}

Prof. Dr. Christoph Leuschner

Plant Ecology and Ecosystem Research, Georg-August University of Göttingen

Prof. Dr. Rainer Marggraf

Agricultural Economics and Rural Development, Georg-August University of Göttingen

Dr. Thomas Becker

Geobotany, University of Trier

\section{Members of the Examination Board}

Reviewer: Prof. Dr. Christoph Leuschner

Plant Ecology and Ecosystem Research, Georg-August University of Göttingen

Second Reviewer: Prof. Dr. Rainer Marggraf

Agricultural Economics and Rural Development, Georg-August University of Göttingen

\section{Further members of the Examination Board}

Prof. Dr. Erwin Bergmeier

Vegetation and Phytodiversity Analysis, Georg-August University of Göttingen

Prof. Dr. Markus Hauck

Plant Ecology and Ecosystem Research, Georg-August University of Göttingen

Prof. Dr. Johannes Isselstein

Institute of Grassland Science, Georg-August University of Göttingen

Prof. Dr. Teja Tscharntke

Agroecology, Georg-August University of Göttingen

Date of the oral examination: 11.12 .2013 


\section{Table of contents}

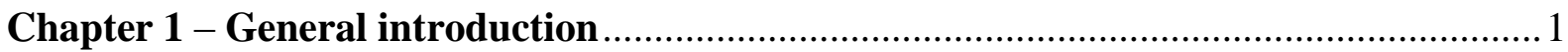

Grassland conservation in Eastern Europe: threats and opportunities .................................. 2

Ecological drivers of grassland diversity: processes at multiple scales.............................. 4

Governance of grassland diversity: the case of common pastures in Romania.....................5

Implications of regional differences in European farmland conservation ............................5

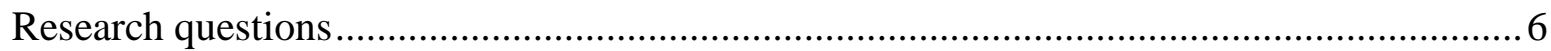

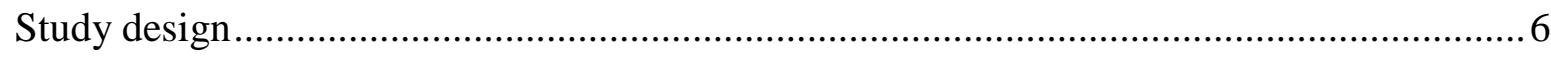

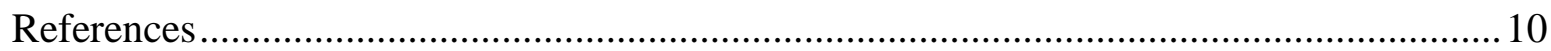

Chapter 2 - Both local and landscape factors determine plant and Orthoptera diversity in the semi-natural grasslands of Transylvania, Romania ............................................ 13

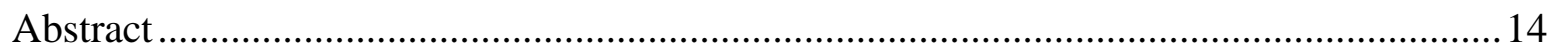

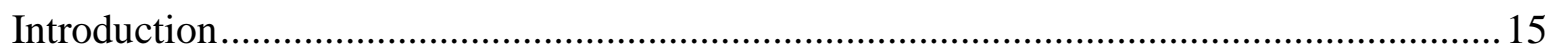

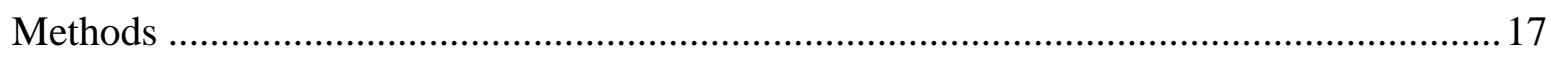

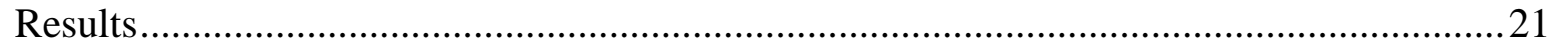

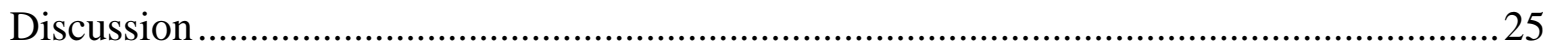

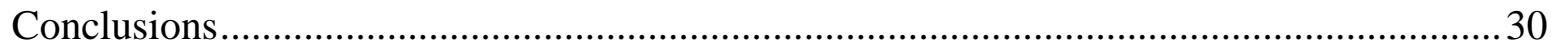

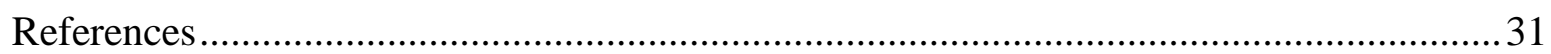

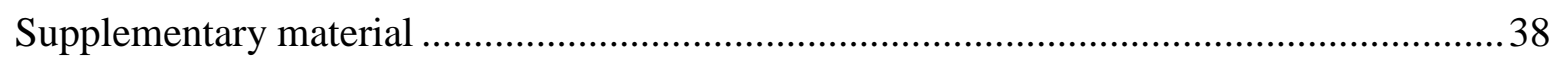

Chapter 3 - Pastoral commons use in Romania and the role of the Common

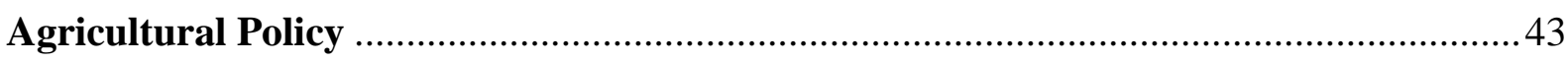

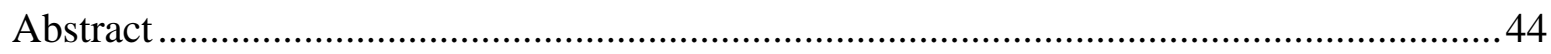

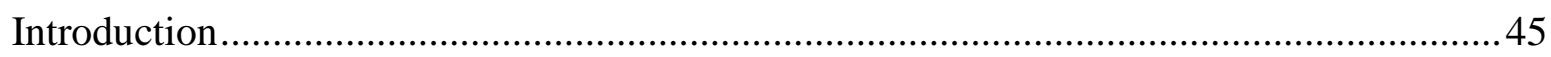

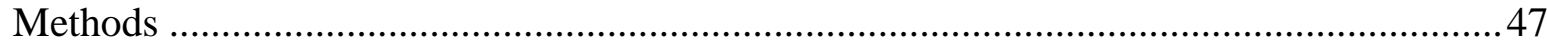

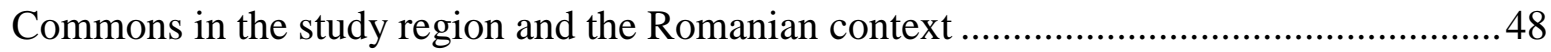

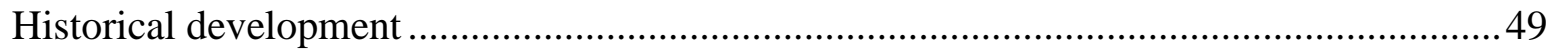

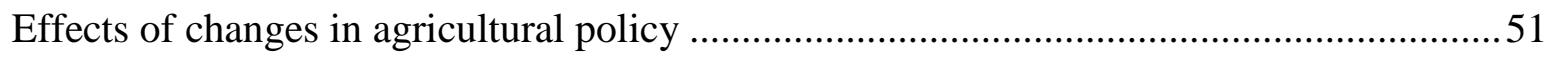

New associations and their effect on commons governance .............................................52

Implications for the sustainability of commons use and future prospects ..........................53

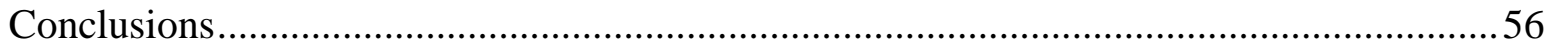

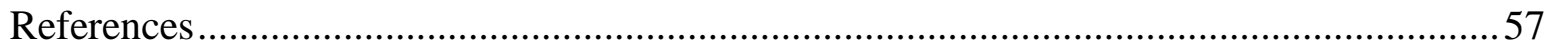




\section{Chapter 4 - Wood-pasture management in Southern Transylvania (Romania): from}

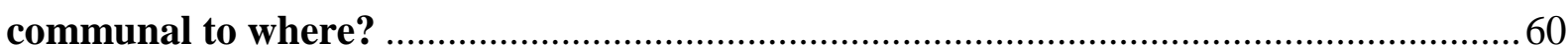

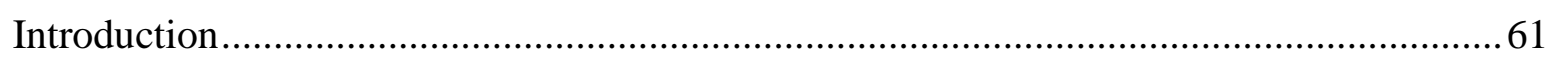

Development and structure of wood-pastures in the Târnava Mare area in Southern

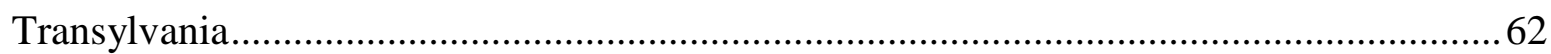

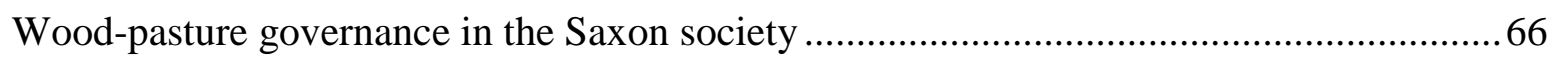

Communism, post-communism and accession to the European Union..............................69

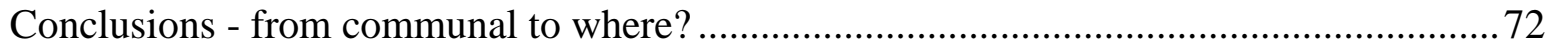

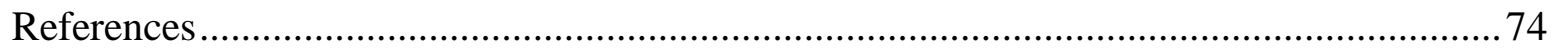

Chapter 5 - Harnessing the biodiversity value of Central and Eastern European

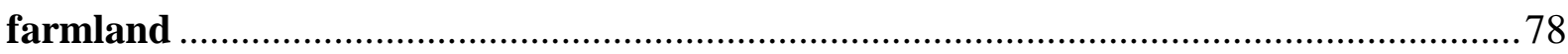

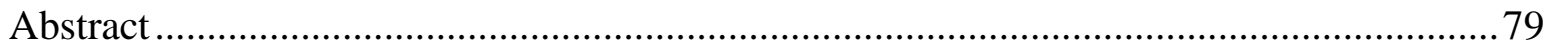

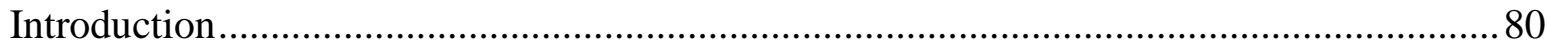

The legacy of communist agriculture in Central and Eastern Europe and its implications for

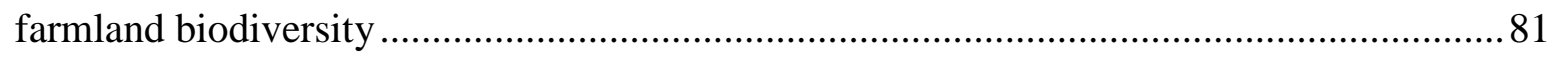

Agricultural habitats in Central and Eastern Europe are underrepresented in the

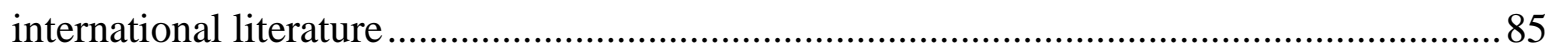

Harnessing the biodiversity value of Central and Eastern European farmland ...................86

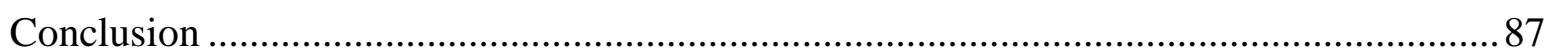

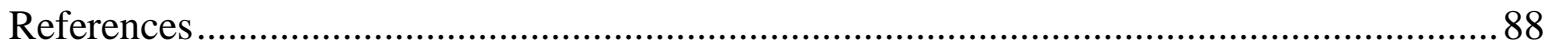

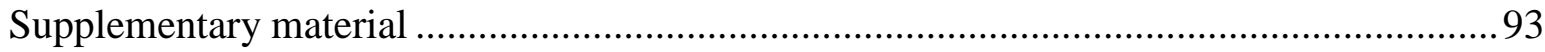

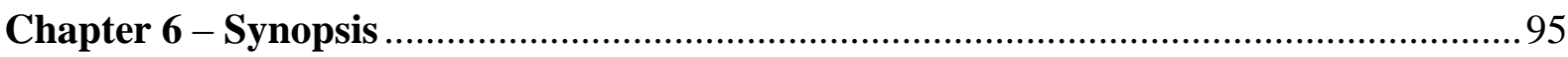

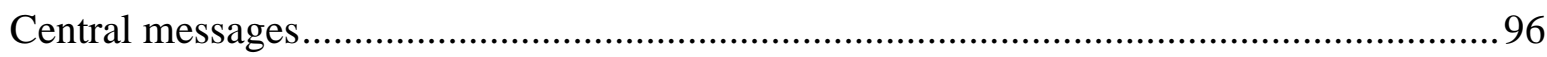

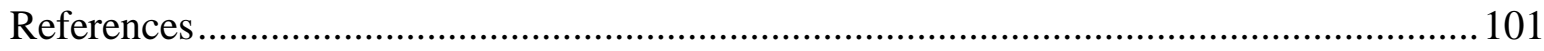

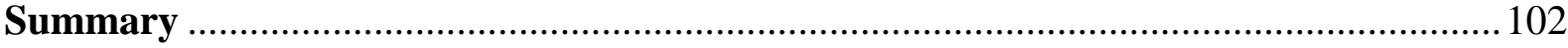

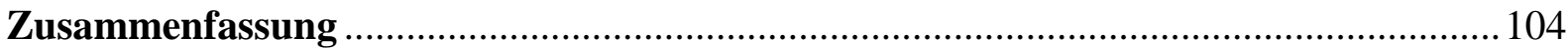

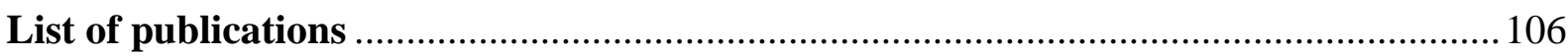

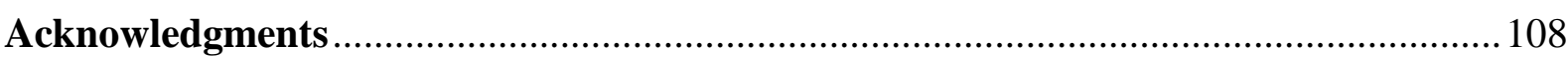

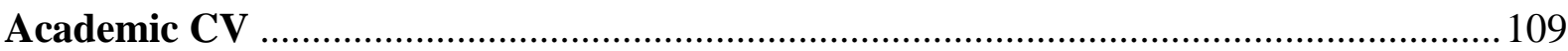




\section{Chapter 1}

General introduction

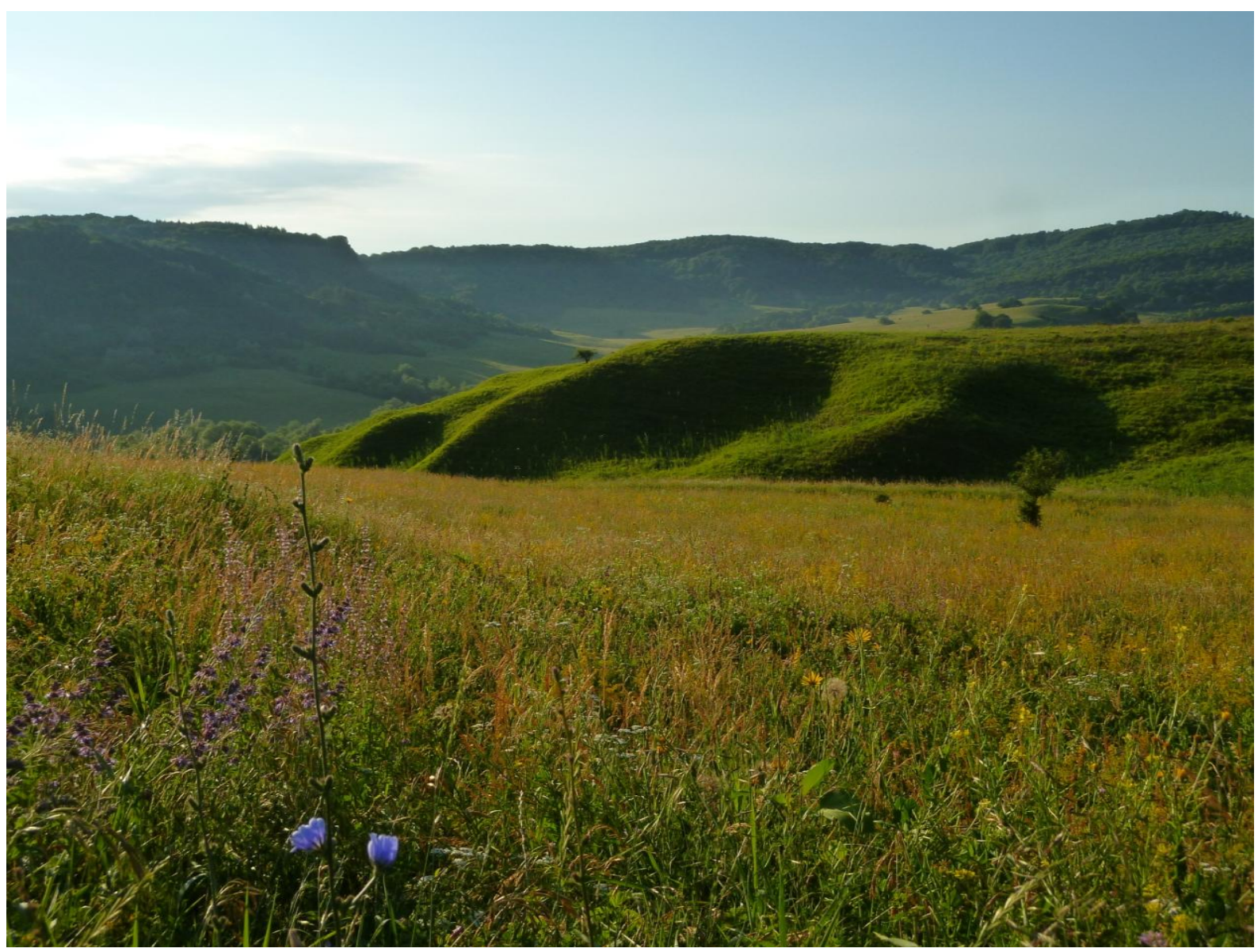




\section{Grassland conservation in Eastern Europe: threats and opportunities}

Semi-natural grasslands are among Europe's most species-rich habitats for many taxonomic groups (Poschlod \& Wallis De Vries 2002), and are an important source of ecosystem services (Bullock et al. 2011). Although they consist of mostly natural (i.e. not sown) vegetation, they are reliant on human management in the form of regular low-intensity grazing or mowing to prevent succession (Poschlod \& Wallis De Vries 2002). These grasslands have played a vital role in livestock farming over millennia of agricultural activity, forming part of a low-intensity cultural landscape that is considered one of Europe's most important natural and cultural heritages (Schmitt \& Rákosy 2007; Hampicke 2013).

The area of semi-natural grassland in Europe has, however, decreased dramatically over the past century. This loss has been driven mainly by intensification through the use of synthetic fertilisers, pesticides and machinery, land use change to more profitable cultivation types, and abandonment (Strijker 2005). Degradation through nitrogen deposition and isolation has additionally reduced grassland diversity and functioning in remaining fragments (Helm, Hanski, \& Pärtel 2006; Krauss et al. 2010; Stevens et al. 2010). As a result, a large proportion of European threatened species are those of semi-natural grassland habitats (Pärtel, Bruun, \& Sammul 2005; van Swaay, Warren, \& Loïs 2006; EEA 2010).

Nevertheless, the situation is regionally highly variable within Europe. Loss of semi-natural grassland has generally been greater in lowland productive areas than in upland marginal areas, and generally more severe in the north and west of Europe than in the south and east (Figure 1). Within the European Union, the eastern new member states ${ }^{1}$ in particular retain a range of species-rich grassland types at large scale, due to the greater prevalence of lowintensity agriculture (Donald et al. 2002; Tryjanowski et al. 2011).

Agricultural intensification has, however, been increasing in the eastern new member states in recent years, putting the long-term survival of these grasslands into question (Stoate et al. 2009). This can be linked particularly to the accession of these countries to the EU, exposing them to strong market forces, as well as rural development measures supporting modernization of farming, which have generally led to greater pressure on biodiversity (Stoate et al. 2009).

\footnotetext{
${ }^{1}$ I.e. the 11 post-communist countries which joined in 2004 (the Czech Republic, Estonia, Hungary, Latvia, Lithuania, Poland, Slovakia and Slovenia), in 2007 (Bulgaria and Romania), and in 2013 (Croatia).
} 


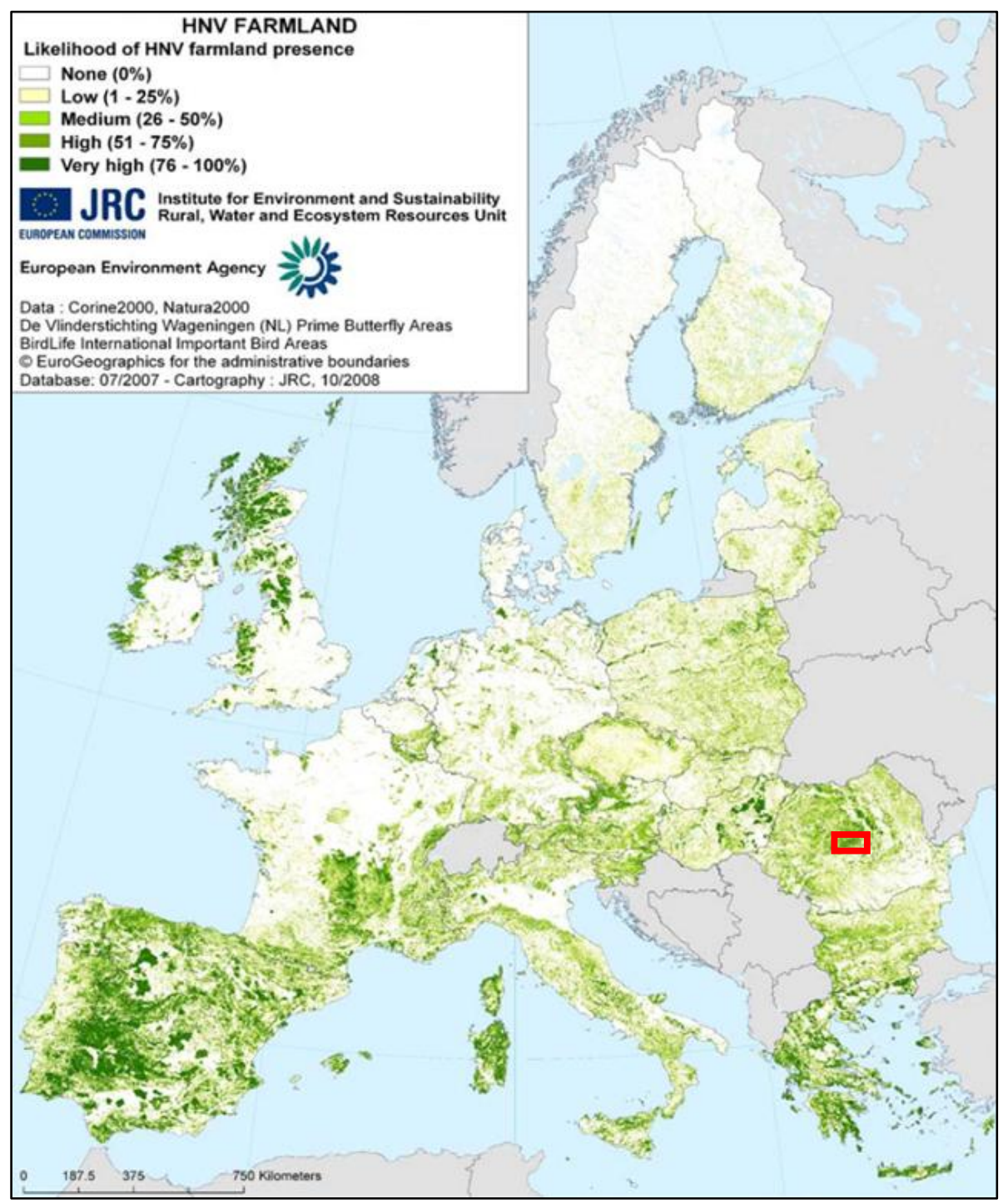

Figure 1 The distribution of semi-natural grasslands has not been mapped at a European scale, however, this land-cover type forms a major element of High Nature Value (HNV) farmland. Once present throughout Europe, the current predicted distribution shown here demonstrates the patchiness of $\mathrm{HNV}$ farmland in the EU, which is likely to reflect the presence of remaining semi-natural grassland. The red box represents the location of the study area in Southern Transylvania (Romania).

In contrast, EU membership also means that the financial and legal support available for conservation of semi-natural grasslands is now greater than ever in Eastern Europe. Among the EU instruments for conservation, agri-environment schemes now play a large role in funding farmland conservation, with a total public expenditure in the EU of $€ 27.8$ billion over the period 2007-2012 (ENRD 2013). Member states are required to offer agri-environment schemes in their rural development plans, but are given a relatively large degree of flexibility to design the scheme according to national or regional priorities (EC 2005). This provides a 
significant opportunity to conserve or restore semi-natural grasslands, although efforts still need to be made to increase scheme effectiveness (Kleijn et al. 2006).

This thesis focuses on issues affecting the conservation of semi-natural grazed grassland in the region of Târnava Mare in Southern Transylvania (Romania: see Figure 1). Most of the grassland in the region is semi-natural, embedded in landscapes of primarily low-intensity farming that are typical for large areas of Eastern Europe. In addition, almost all grazed grassland in the region is common land, a system of collective use that applies to several millions of hectares of land in Europe, particularly in the south and east (Eurostat 2013). The area thus represents many of the problems associated with both the ecological and the human aspects of conserving this man-made habitat at large scales.

\section{Ecological drivers of grassland diversity: processes at multiple scales}

Effective conservation measures for semi-natural grassland require a good understanding of the ecological processes affecting these communities. These processes may act at multiple scales, from local (e.g. microclimate or soil nutrient status) to landscape (e.g. the availability of pollinators or the connectivity of meta-populations), and national/global scale (e.g. weather patterns). Conservation measures such as agri-environment schemes almost always target local processes, which are relatively easily influenced through management prescriptions for a given grassland. The landscape scale is, in contrast, only rarely addressed (Kleijn et al. 2011), despite the fact that increasing numbers of studies suggest that the characteristics of the surrounding landscape can also significantly affect grassland diversity (e.g. Cousins \& Aggemyr 2008; Marini et al. 2008; Janišová et al. 2013). This is due in part to organizational barriers, as it frequently requires cooperation between multiple land managers (Prager, Reed, $\&$ Scott 2012), but also to the imperfect understanding of processes driving landscape effects (Tscharntke et al. 2012).

To date, the majority of research on landscape effects has been carried out in highly modified landscapes in Western Europe, and relatively little is known about community responses in semi-natural landscapes such as are common in Romania (but see e.g. Batáry et al. 2007; Körösi et al. 2012 for rare examples from other areas of Eastern Europe). Given that species responses can differ considerably between regions (Tryjanowski et al. 2011; Reif et al. 2011), data from less well-studied, semi-natural areas is therefore needed to better understand landscape scale effects, as well as to inform the design of locally appropriate conservation measures. 


\section{Governance of grassland diversity: the case of common pastures in Romania}

Next to good design, the ability of land managers to implement grassland conservation measures is essential for their success. This depends on a number of factors, including their knowledge about and attitudes towards a measure, but also in some cases their cooperation with other land managers and members of the local community. The latter is particularly relevant for grasslands in Romania, where roughly half of all permanent pasture is managed as common land (INS 2010), meaning that the land may be owned by an individual, a group or the state, but it is used collectively by members of the local community.

Successful commons management relies on stable institutions that are monitored and enforced (Ostrom 1990). However, the relatively rapid changes over the past 70 years in Romania including the suppression of family farming during the communist regime, the chaotic period of property restitution and economic difficulty in the post-communist era, and recently the influence of EU policies and markets - have destabilised the historic commons institutions. As a result, many pastures of high nature value, including species-rich dry grasslands and wood-pastures with ancient solitary trees, are at risk of poor management due to lack of cooperation between their users. In order to provide effective conservation in the future, it is necessary to know what changes are occurring in the governance of the pastures in the region, and how the commons institutions could adapt to the current circumstances.

\section{Implications of regional differences in European farmland conservation}

With the accession to the EU of 11 post-communist eastern European countries between 2004 and 2013, applying a locally appropriate yet coherent farmland conservation policy across the EU has become significantly more challenging. The effectiveness of a conservation measure can depend on a number of factors, including the ecological characteristics of the region, the type of farming, other interacting policies, the general economic situation, and the attitudes of the farmers and local populations (e.g. Herzon \& Mikk 2007). Whilst these ecological, social, political or cultural frameworks are individually naturally variable between regions, when considered in combination, it appears that the eastern and western EU member states form two quite different regions (Liira et al. 2008; Storkey et al. 2012). This is largely due to the historical effects of the communist regime, as well as the subsequent period of transition to the market economy, which have caused a divergence in the farmland conservation context between west and east. However, differences between the two regions are rarely addressed in 
research, policy and practice, which are still strongly biased towards western European farming systems, leading to the application of potentially ineffective measures (Tryjanowski et al. 2011).

\section{Research questions}

In the context of the above description of the threats and opportunities facing the conservation, biodiversity and governance of semi-natural grasslands in Eastern Europe, this thesis investigates the following questions, focussing on the study area of Southern Transylvania, Romania:

i. What is the relative importance of local and landscape factors in driving diversity in species-rich grassland in Southern Transylvania? Which ecological processes are potentially causing these effects? (Chapter 2)

ii. How is the role of common pastures changing for livestock owners in Southern Transylvania? What internal and external factors are driving this? (Chapter 3)

iii. What are the current barriers to the effective functioning of commons institutions in Southern Transylvania? How can commons governance adapt to provide sustainable management into the future? (Chapter 4)

iv. How can we address the divide between Eastern and Western Europe in farmland conservation to provide better support for both biodiversity and rural communities? (Chapter 5)

\section{Study design}

This study was carried out within the interdisciplinary $\mathrm{PhD}$ programme "Biodiversity and Society", and addresses both ecological and governance aspects of the conservation of seminatural pastures in Southern Transylvania, in the wider context of European farmland conservation. The research was carried out in close cooperation with the local NGO Fundatia ADEPT Transilvania, which works together with local farming communities to promote rural development and biodiversity protection through low-intensity farming.

The study area is in the Târnava Mare region in the south of the Transylvanian plateau, enclosed within the southern arc of the Carpathian Mountains (Figure 2). It has a temperatecontinental climate with a mean annual temperature of $8.8{ }^{\circ} \mathrm{C}$ (Akeroyd et al. 2003), and 
elevation ranges between 500 and $700 \mathrm{~m}$ a.s.1.. The area is characterised by low-intensity farming, often without the use of mechanisation or synthetic fertilisers or pesticides, which is typical for Transylvania and indeed large areas of Eastern Europe. The prevalence of valuable habitats and species has led to the area being recognised as a Site of Community Importance (SCI) under the EU Habitats Directive: this designation may have considerable influence over the future development in the region, but currently does not significantly alter management practices.

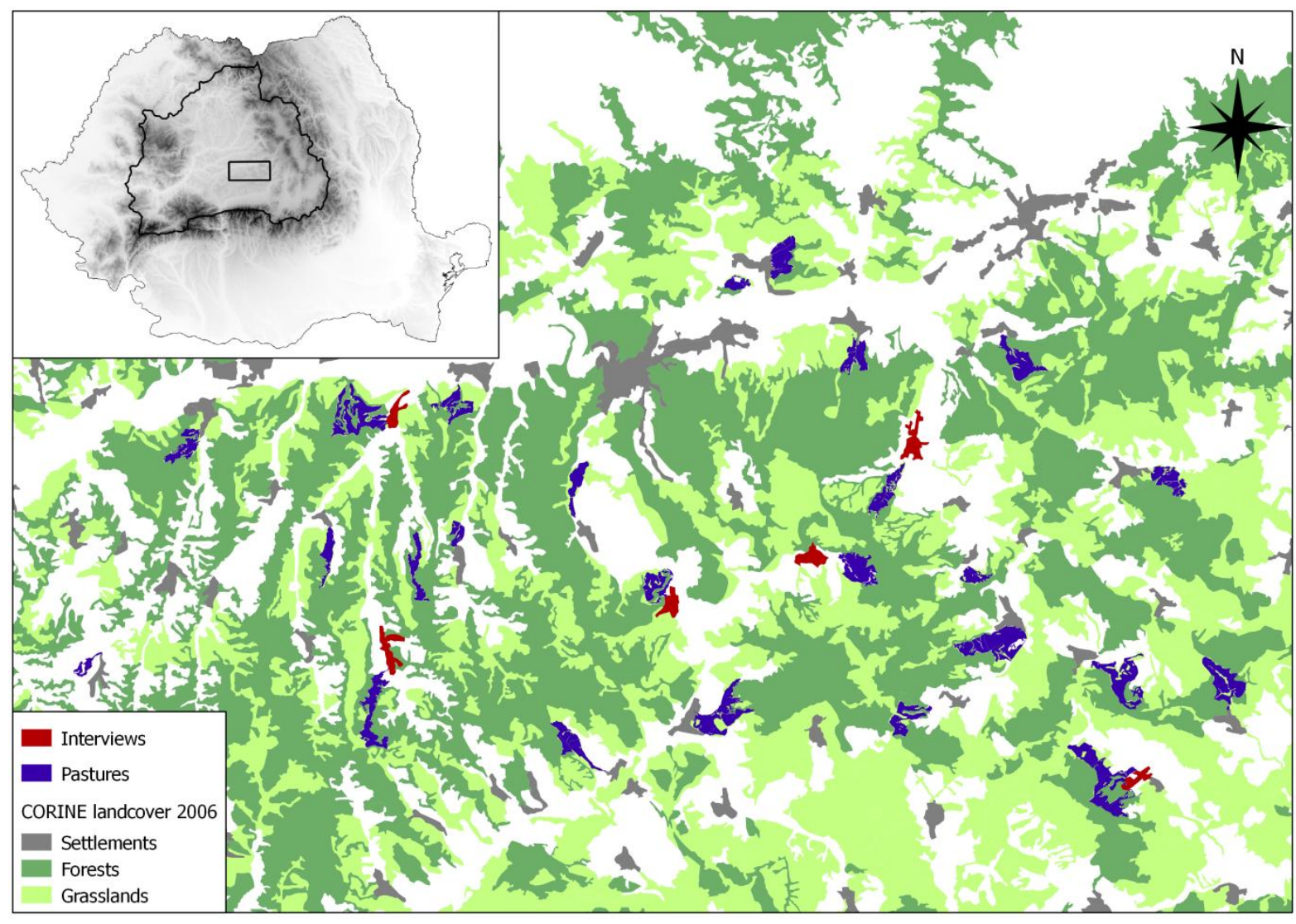

Figure 2 Location of the 25 pastures surveyed in this study (blue) and the 6 villages in which interviews were carried out (red) in the region of Southern Transylvania (Lat. 46.1434 ${ }^{\circ}$ Long. $24.7882^{\circ}$ ). The inset is a digital elevation map of Romania showing the region of Transylvania (thick black line) within the arch of the Carpathian Mountains, and the study area (black box). Land-cover data: CORINE 2006, DEM: Diva-GIS free spatial data. 
Approximately $30 \%$ of the region is covered in grassland, almost all of which is semi-natural. Eight types of grass or scrubland habitats in Annex I of the Habitats Directive have been identified in the region, ranging from sub-pannonic steppic grasslands (Festucion valesiacae), usually found on steeper south or southwest facing slopes of pastures, to lowland alluvial Cnidion dubii meadows in the valley bottoms (Oroian 2009). Additionally, roughly $7 \%$ of the grassland area is covered by wood-pastures (Figure 3), which contain scattered trees and bushes that provide a structurally rich habitat for a variety of plant and animal species (Hartel et al. 2013). The vast majority of pasture in the study area is communal land, whilst hay meadows are usually privately owned. Pastures are usually located on hilly or rough terrain, and are generally large areas of continuous grassland (up to around 1000 ha), although they may not be managed as one unit.

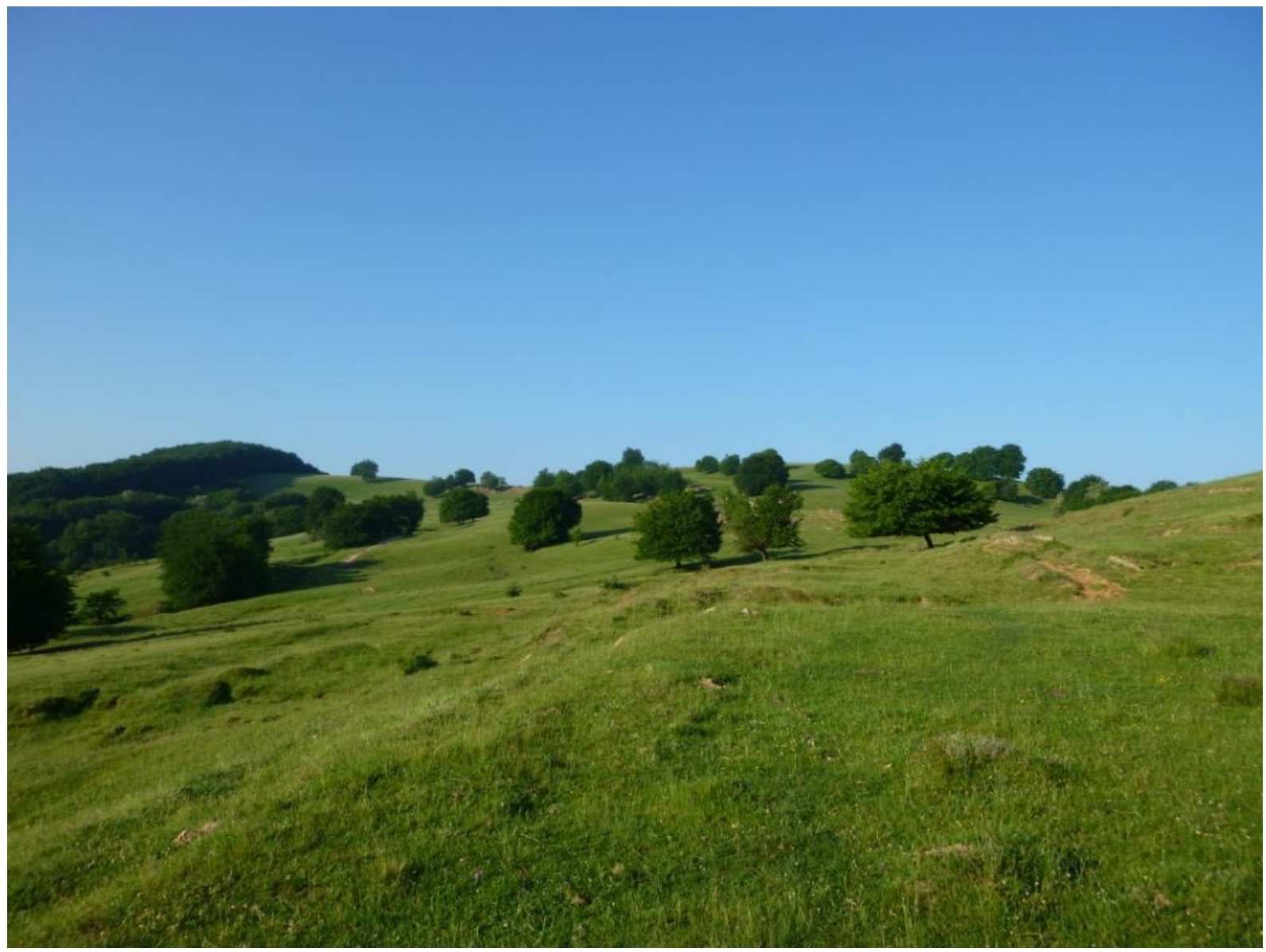

Figure 3 Typical pasture in the study region, showing the scattered trees of a wood-pasture in the background (Photo: L. Sutcliffe, 2011). 
Within the study area, I collected ecological data in 25 cattle-grazed pastures in the summers of 2011 and 2012. I identified all vascular plant species in three plots of $1000 \mathrm{~m}^{2}$ per pasture, and surveyed Orthoptera (grasshoppers, crickets and bush crickets) in the same plots using sweep netting. I measured local variables within each plot (aspect, slope, soil nitrogen content, soil carbon content, soil $\mathrm{pH}$ and vegetation height), as well as landscape variables by mapping the land cover types within $500 \mathrm{~m}, 1 \mathrm{~km}, 2 \mathrm{~km}$ and $3 \mathrm{~km}$ radii from each plot using GIS (Geographic Information Systems). This data is analysed in Chapter 2, using generalized linear mixed models (GLMM) to examine the local and landscape variables influencing species richness, and constrained ordination to identify the effects of these variables on community composition.

In summer 2011, I additionally carried out a pilot study to gather information about the history, current structure, and problems of the local common grazing governance system. This consisted of ten qualitative, semi-structured interviews with commons users and NGO representatives from seven villages in the study area. The results are discussed in Chapter 3. Based on this information, six villages were selected - three with well-functioning, and three with poorly-functioning commons systems. In each village, I carried out five semi-structured interviews (alone or with a translator) with livestock owners as well as current and former members of the local administration in summer 2012. The interviews were transcribed and coded in order to examine current barriers and opportunities for commons governance in the region. The findings are presented in Chapter 4, alongside an analysis of the historical governance based on information from the literature.

In February 2013, I was the main organiser for a 3 day workshop on the subject of "East meets West - transferring conservation approaches between Eastern and Western European landscapes" with 45 international researchers from 21 European countries (eastwest2013.wordpress.com). The aim of the workshop was to examine the nature of the differences between eastern and western European countries, and potential ways to use this information to make conservation approaches more effective in both regions. The conclusions from the presentations and discussions during the workshop are synthesised in Chapter 5.

Finally, Chapter 6 presents the central messages from the four studies in this thesis, and draws conclusions from the findings for conservation research, policy and practice. 


\section{References}

Akeroyd, J.R., Sârbu, A., Oroian, S. \& Hiriţiu, M. (2003) Botanical Assessment of the Saxon Villages Region (Târnava Plateau) of Southern Transylvania, Romania. Fundația ADEPT Transilvania, Saschiz, Romania.

Batáry, P., Orci, K.M., Báldi, A., Kleijn, D., Kisbenedek, T. \& Erdős, S. (2007) Effects of local and landscape scale and cattle grazing intensity on Orthoptera assemblages of the Hungarian Great Plain. Basic and Applied Ecology, 8, 280-290.

Bullock, J.M., Jefferson, R.G., Blackstock, T.H., Pakeman, R.J., Emmett, B.A., Pywell, R.J., Grime, J.P. \& Silvertown, J. (2011) Semi-natural Grasslands. The UK National Ecosystem Assessment Technical Report pp. 161-196. UNEP-WCMC, Cambridge.

Cousins, S.A.O. \& Aggemyr, E. (2008) The influence of field shape, area and surrounding landscape on plant species richness in grazed ex-fields. Biological Conservation, 141, $126-135$.

Donald, P.F., Pisano, G., Rayment, M.D. \& Pain, D.J. (2002) The Common Agricultural Policy, EU enlargement and the conservation of Europe's farmland birds. Agriculture, Ecosystems \& Environment, 89, 167-182.

EC. (2005) Agri-environment Measures. Overview on General Principles, Types of Measures and Applications. European Commission Directorate General for Agriculture and Rural Development, Brussels.

EEA. (2010) EU 2010 Biodiversity Baseline. European Environment Agency, Copenhagen.

ENRD. (2013) State of the Total Public and EAFRD Expenditure Per Measure. European Network for Rural Development, Brussels.

Eurostat. (2013) Common land statistics - backgrounds. European Commission, Brussels. http://epp.eurostat.ec.europa.eu/statistics_explained/index.php/Common_land_statistics_ __backgrounds [Accessed 03.11.2013].

Hampicke, U. (2013) Kulturlandschaft Und Naturschutz. Probleme - Konzepte - Ökonomie [Cultural landscapes and nature conservation. Problems - concepts - economics]. Springer-Spektrum, Wiesbaden.

Hartel, T., Dorresteijn, I., Klein, C., Máthé, O., Moga, C.I., Öllerer, K., Roellig, M., von Wehrden, H. \& Fischer, J. (2013) Wood-pastures in a traditional rural region of Eastern Europe: Characteristics, management and status. Biological Conservation, 166, 267-275.

Helm, A., Hanski, I. \& Pärtel, M. (2006) Slow response of plant species richness to habitat loss and fragmentation. Ecology Letters, 9, 72-77.

Herzon, I. \& Mikk, M. (2007) Farmers' perceptions of biodiversity and their willingness to enhance it through agri-environment schemes: A comparative study from Estonia and Finland. Journal for Nature Conservation, 15, 10-25. 
INS. (2010) Anuarul Statistic Al României 2010 [The Statistical Yearbook of Romania]. Institutul National de Statistica, Bucharest.

Janišová, M., Michalcová, D., Bacaro, G. \& Ghisla, A. (in press) Landscape effects on diversity of semi-natural grasslands. Agriculture, Ecosystems \& Environment, http://dx.doi.org/10.1016/j.agee.2013.05.022.

Kleijn, D., Baquero, R.A., Clough, Y., Díaz, M., De Esteban, J., Fernández, F., Gabriel, D., Herzog, F., Holzschuh, A., Jöhl, R., Knop, E., Kruess, A., Marshall, E.J.P., SteffanDewenter, I., Tscharntke, T., Verhulst, J., West, T.M. \& Yela, J.L. (2006). Mixed biodiversity benefits of agri-environment schemes in five European countries. Ecology Letters, 9, 243-254.

Kleijn, D., Rundlöf, M., Scheper, J., Smith, H.G. \& Tscharntke, T. (2011) Does conservation on farmland contribute to halting the biodiversity decline? Trends in Ecology \& Evolution, 26, 474-481.

Kőrösi, Á., Batáry, P., Orosz, A., Rédei, D. \& Báldi, A. (2012) Effects of grazing, vegetation structure and landscape complexity on grassland leafhoppers (Hemiptera: Auchenorrhyncha) and true bugs (Hemiptera: Heteroptera) in Hungary. Insect Conservation and Diversity, 5, 57-66.

Krauss, J., Bommarco, R., Guardiola, M., Heikkinen, R.K., Helm, A., Kuussaari, M., Lindborg, R., Öckinger, E., Pärtel, M., Pino, J., Pöyry, J., Raatikainen, K.M., Sang, A., Stefanescu, C., Teder, T., Zobel, M. \& Steffan-Dewenter, I. (2010) Habitat fragmentation causes immediate and time-delayed biodiversity loss at different trophic levels. Ecology Letters, 13, 597-605.

Liira, J., Aavik, T., Parrest, O. \& Zobel, M. (2008) Agricultural Sector, Rural Environment and Biodiversity in the Central and Eastern European EU Member States. AGD Landscape \& Environment, 2, 46-64.

Marini, L., Fontana, P., Scotton, M. \& Klimek, S. (2008) Vascular plant and Orthoptera diversity in relation to grassland management and landscape composition in the European Alps. Journal of Applied Ecology, 45, 361-370.

Oroian, S. (2009). Flora si vegetatia satelor sasesti din sud-estul Transilvaniei [The flora and vegetation of the Saxon villaging in southeastern Transylvania]. University Press, Târgu Mureş, Romania.

Ostrom, E. (1990) Governing the Commons: The Evolution of Institutions for Collective Action. Cambridge University Press, New York.

Pärtel, M., Bruun, H.H. \& Sammul, M. (2005) Biodiversity in temperate European grasslands: origin and conservation. Integrating efficient grassland farming and biodiversity. Grassland Science in Europe 10 (eds R. Lillak, R. Viiralt, A. Linke \& V. Geherman), pp. 1-14. Estonian Grassland Society, Tartu.

Poschlod, P. \& Wallis De Vries, M.F. (2002) The historical and socioeconomic perspective of calcareous grasslands-lessons from the distant and recent past. Biological Conservation, 104, 361-376. 
Prager, K., Reed, M. \& Scott, A. (2012) Encouraging collaboration for the provision of ecosystem services at a landscape scale-Rethinking agri-environmental payments. Land Use Policy, 29, 244-249.

Reif, J., Böhning-Gaese, K., Flade, M., Schwarz, J. \& Schwager, M. (2011) Population trends of birds across the iron curtain: Brain matters. Biological Conservation, 144, 2524-2533.

Schmitt, T. \& Rákosy, L. (2007) Changes of traditional agrarian landscapes and their conservation implications: a case study of butterflies in Romania. Diversity and Distributions, 13, 855-862.

Stevens, C.J., Duprè, C., Dorland, E., Gaudnik, C., Gowing, D.J.G., Bleeker, A., Diekmann, M., Alard, D., Bobbink, R., Fowler, D., Corcket, E., Mountford, J.O., Vandvik, V., Aarrestad, P.A., Muller, S. \& Dise, N.B. (2010) Nitrogen deposition threatens species richness of grasslands across Europe. Environmental Pollution, 158, 2940-2945.

Stoate, C., Báldi, A., Beja, P., Boatman, N.D., Herzon, I., van Doorn, A., de Snoo, G.R., Rakosy, L. \& Ramwell, C. (2009) Ecological impacts of early 21st century agricultural change in Europe - A review. Journal of Environmental Management, 91, 22-46.

Storkey, J., Meyer, S., Still, K.S. \& Leuschner, C. (2012) The impact of agricultural intensification and land-use change on the European arable flora. Proceedings of the Royal Society B: Biological Sciences, 279, 1421-1429.

Strijker, D. (2005) Marginal lands in Europe - causes of decline. Basic and Applied Ecology, 6, 99-106.

van Swaay, C., Warren, M. \& Loïs, G. (2006) Biotope Use and Trends of European Butterflies. Journal of Insect Conservation, 10, 189-209.

Tryjanowski, P., Hartel, T., Báldi, A., Szymański, P., Tobolka, M., Herzon, I., Goławski, A., Konvička, M., Hromada, M., Jerzak, L., Kujawa, K., Lenda, M., Orłowski, G., Panek, M., Skórka, P., Sparks, T.H., Tworek, S., Wuczyński, A. \& Żmihorski, M. (2011) Conservation of farmland birds faces different challenges in Western and CentralEastern Europe. Acta Ornithologica, 46, 1-12.

Tscharntke, T., Tylianakis, J.M., Rand, T.A., Didham, R.K., Fahrig, L., Batáry, P., Bengtsson, J., Clough, Y., Crist, T.O., Dormann, C.F., Ewers, R.M., Fründ, J., Holt, R.D., Holzschuh, A., Klein, A.M., Kleijn, D., Kremen, C., Landis, D.A., Laurance, W., Lindenmayer, D., Scherber, C., Sodhi, N.S., Steffan-Dewenter, I., Thies, C., van der Putten, W.H. \& Westphal, C. (2012) Landscape moderation of biodiversity patterns and processes - eight hypotheses. Biological Reviews, 87, 661-685. 


\section{Chapter 2}

\section{Both local and landscape factors determine plant and Orthoptera diversity in the semi-natural grasslands of Transylvania, Romania}

Laura M.E. Sutcliffe, Péter Batáry, Thomas Becker, Kirill Márk Orci \& Christoph Leuschner

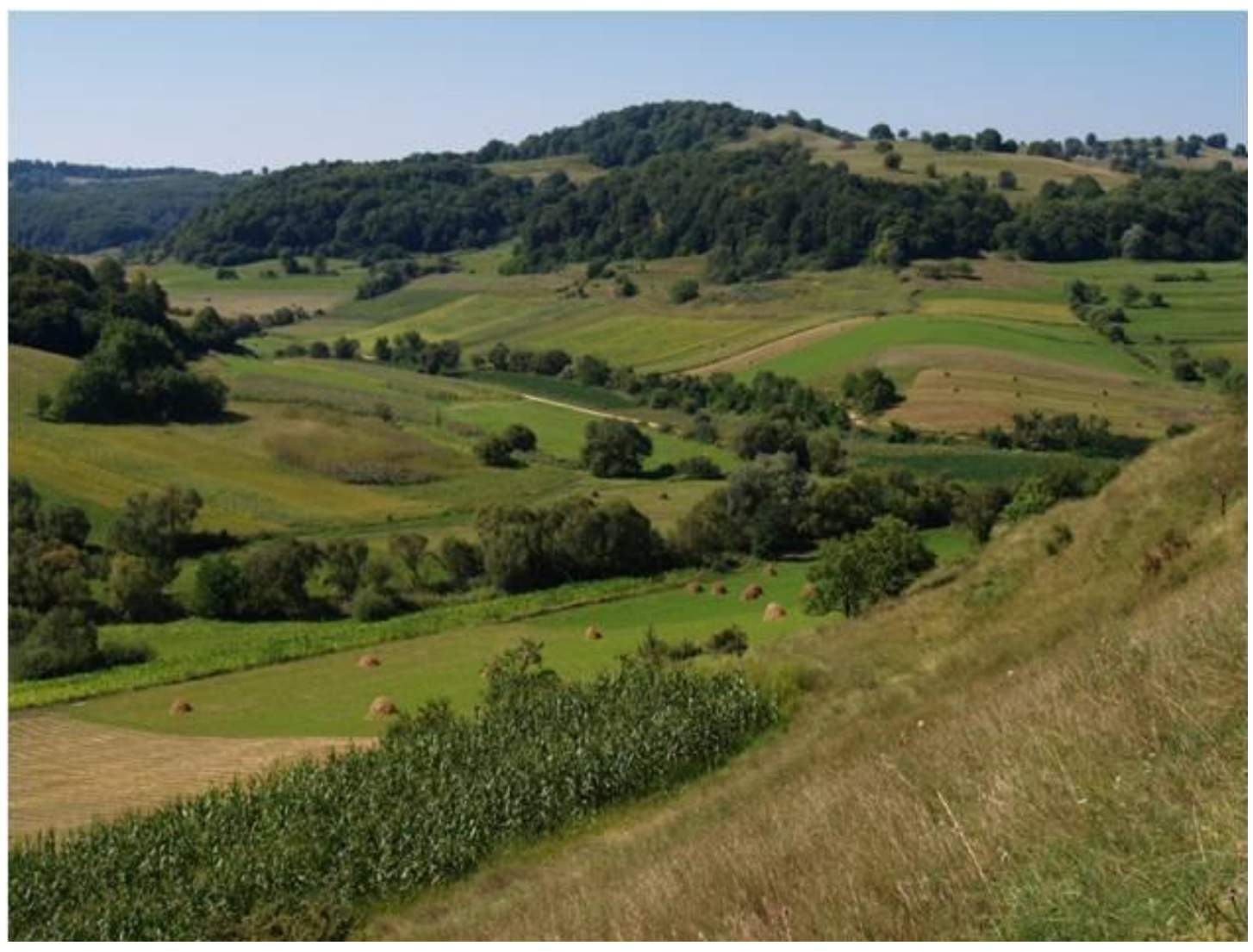

Submitted 


\begin{abstract}
Semi-natural grassland supports a large proportion of biodiversity and ecosystem services in Europe, however, it is continuing to be destroyed or degraded. In addition to the clear role of local management in these processes, there is increasing evidence for wider landscape-scale effects on species richness and community composition of plants and animals. Most of this evidence comes from studies in highly altered western European landscapes with only fragments of remaining semi-natural grassland. In contrast, Eastern European countries such as Romania still contain large areas of semi-natural grassland, but this habitat is threatened by agricultural intensification and homogenization. We analyzed vascular plant and Orthoptera communities from species-rich pastures in Southern Transylvania, Romania, against a range of local and landscape factors. Species richness of plants had a highly significant positive relationship with landscape heterogeneity. Orthoptera species richness and abundance were negatively correlated with plant species richness, and increased with proportion of grassland in the landscape and local vegetation height. The results suggest that large and species-rich grassland communities can be significantly affected by both local and landscape scale land use changes, but effects can vary within and between taxonomic groups. Conservation measures such as agri-environment schemes should therefore seek to address landscape scale processes better, promoting a range of low-intensity land use practices in order to support a variety of landscape types.
\end{abstract}

Keywords: Agricultural intensification; Community composition; Farmland biodiversity; Grasshopper; Landscape heterogeneity; Species-rich grassland; Eastern Europe 


\section{Introduction}

Semi-natural grasslands are among Europe's most species-rich habitats for many taxonomic groups (Poschlod and Wallis De Vries 2002; Wilson et al. 2012), and are a significant source of ecosystem services (for example carbon sequestration, pollination, recreation and plant wild relatives: Bullock et al. 2011). However, the extent of semi-natural grassland has declined dramatically in Europe over the past 60 years, mainly through the processes of agricultural intensification, abandonment and land-use change (Strijker 2005). The remaining areas have been negatively affected by fragmentation (Helm et al. 2006; Raatikainen et al. 2008; Krauss et al. 2010) and other deleterious external influences, such as eutrophication through atmospheric nitrogen deposition (Stevens et al. 2010). As a result, a large proportion of threatened species in Europe are those of semi-natural grassland habitats (Pärtel et al. 2005; van Swaay et al. 2006; EEA 2010), and increasing numbers of studies are devoted to understanding the ecological processes affecting grassland biodiversity in order to improve conservation and restoration measures (e.g. Koper and Nudds 2011).

Whilst the effects of local factors, such as environmental and management conditions, on grassland biodiversity have long been intensively studied (Ellenberg and Leuschner 2010), researchers have only relatively recently started to investigate the more complex effects of landscape context on grassland biodiversity (Prevedello and Vieira 2010). The majority of these studies have focused on animal responses (Prevedello and Vieira 2010), however, an increasing number of studies have also shown responses in sessile organisms such as vascular plants (e.g. Öckinger et al. 2012; Reitalu et al. 2012; Schmucki et al. 2012; Janišová et al. 2013). The properties of the surrounding landscape can significantly affect local species richness and composition in habitat patches through a number of mechanisms. For example, the types of surrounding habitat can influence the landscape-wide species pool, facilitate or hinder dispersal and biotic interactions between taxa, or select for different species traits in the local community (Tscharntke et al. 2012). Spatial heterogeneity of land-cover types is a particularly important landscape metric in this context, which can be separated into compositional (variety of different land cover types) and configurational (complexity of the spatial patterning of cover types) heterogeneity (Fahrig et al. 2010). Landscape structure may also interact with local factors and moderate their effects on biodiversity, with major implications for the efficacy of conservation interventions such as agri-environment measures (Concepción et al. 2008; Batáry et al. 2010). 
The importance of landscape-scale approaches to farmland conservation has been increasingly stressed in recent years (e.g. Fuentes-Montemayor et al. 2011; Hiron et al. 2013; McKenzie et al. 2013). Nevertheless, landscape factors have so far been largely neglected in management measures such as agri-environment schemes (but see e.g. Verhulst et al. 2006), partly due to the lack of a clear understanding of their effects. Studies suggest that the effects on animals are greater than those on plants (Dauber et al. 2003; Marini et al. 2008; Jonason et al. 2011), and that mobile animal species respond more strongly than sedentary ones (Marini et al. 2010): this is probably due to the greater relative influence of local factors on both plants and sedentary animals. For both plants and animals, habitat or food generalists tend to respond more positively to landscape heterogeneity than specialists, as they can benefit more from the greater range of resources available (Batáry et al. 2007a; Rösch et al. 2013).

Whilst the evidence for landscape effects in Europe is increasing, these studies have mostly been carried out in the highly modified and intensified landscapes of northern and western Europe - as is the case for agro-ecological studies in general (Báldi and Batáry 2011; Tryjanowski et al. 2011; Uthes and Matzdorf 2013). Despite several recent landscape-scale studies from Eastern Europe (e.g. Batáry et al. 2007b; Aavik et al. 2008; Körösi et al. 2012; Janišová et al. 2013), there is still relatively little evidence on species responses at this scale in the large areas of low-intensity farmland in eastern countries such as Romania. Several studies suggest that species responses are highly context dependent and can differ between regions, especially between the extensive farmland often found in Eastern Europe and the more intensively studied, and farmed, areas of Western Europe (Báldi and Batáry 2011; Reif et al. 2011; Tryjanowski et al. 2011; Szymkowiak et al. 2014).

This study therefore analyses grassland vascular plant and Orthoptera communities in speciesrich grasslands in Transylvania, Romania, along a gradient of landscape compositional heterogeneity and a gradient of disturbance. By investigating two taxonomic groups, and multiple functional types within those groups, we test: i) which local and landscape factors affect species richness and composition of each of the taxonomic groups; and ii) which functional groups show the greatest response to landscape effects, and therefore which mechanisms may be driving these effects. To our knowledge, this is one of the first studies comparing local and landscape effects on plant and insect communities in low-intensity farmland in Eastern Europe, and one of very few considering large-scale species-rich grasslands. 


\section{Methods}

Study area and sampling design

The study area was within a $30 \mathrm{~km}$ radius of the town of Sighişoara in Southern Transylvania, Romania, in the foothills of the Carpathian Mountains (for locations of surveyed plots and pastures see Figure S1, supplementary material: mean altitude \pm SEM $524.6 \pm 10.1 \mathrm{~m}) .75$ plots of $1000 \mathrm{~m}^{2}$ each were sampled in total, nested within 25 pastures (i.e. 3 plots per pasture). The pastures were selected as those grazed mainly by cattle (and having a continuous history of cattle grazing for at least the last 50 years), with a minimum distance between the pastures of $1 \mathrm{~km}$. The pastures were also selected to provide a gradient of landscape heterogeneity, measured as Shannon diversity, i.e. richness and evenness of land use types within a $3 \mathrm{~km}$ radius of the pasture. Pastures were generally large (mean \pm SEM: $121.8 \pm 7.6 \mathrm{ha}$ ), and there had been no application of agrochemicals (or in some areas at least not for the last 20 years). Grazing pressure was low (on average well under 1 livestock unit per hectare), but locally variable due to the pattern of grazing: cattle herds enter the pasture in the morning, are directed by the herder during the day, and return to the village at night. The 3 plots per pasture were therefore placed along a gradient of relative disturbance by grazing. The highest disturbance plot was located close to the main entrance to the pasture (herd passing twice a day), intermediate in the middle of the pasture, and lowest disturbance furthest from the entrance to the pasture (herds passing very rarely). Sampling was designed to maximize the number of landscapes rather than the number of sample sites to increase effective sample size (Fahrig et al. 2010). Plots were selectively located to maximize the distance between them (mean \pm SEM $=1.03 \pm 0.05 \mathrm{~km}$ ), ensuring they were in areas of relatively homogenous vegetation and topography (slope $<10^{\circ}$ ). Minimum distance to the pasture edge was $20 \mathrm{~m}$. We recorded presence of vascular plant species in plots of $1000 \mathrm{~m}^{2}$ once between May-August, either in 2011 or 2012, including a nested subplot of $10 \mathrm{~m}^{2}$ in which plant cover was additionally estimated in percent. Nomenclature of vascular plants follows Speta and Rákosy (2010). All plant data has been entered into the Global Index of Vegetation-Plot Databases (www.givd.info). We sampled Orthoptera once in each plot in August 2012 by sweep-netting (150 sweeps per plot, net aperture diameter $38 \mathrm{~cm}$ ) in a zigzag transect across the $1000 \mathrm{~m}^{2}$ area, in order to obtain comparable (but not comprehensive) samples (Gardiner et al. 2005). Surveys took place between 10 am and 5 pm on sunny days without high winds or rainfall, and all captured adult Orthoptera individuals were transferred to alcohol for later identification. 


\section{Landscape variables}

We mapped land use in $500 \mathrm{~m}, 1 \mathrm{~km}, 2 \mathrm{~km}$, and $3 \mathrm{~km}$ radii from each plot in GIS (Quantum GIS Development Team 2013, version 1.8.0) using satellite imagery (Google Earth plugin) and ground truthing. Polygons were classified into nine land use categories: arable, grassland, forest, scrub (grassland with $>40 \%$ scrub), orchards, rivers, ponds and lakes, roads, built-up areas. From these, landscape heterogeneity was calculated using the Shannon-index, reflecting richness and evenness of the different land use types. Preliminary Spearman's rank correlation tests and scatter plots showed that landscape heterogeneity and grassland percentage in a $2 \mathrm{~km}$ radius were the most consistently significant landscape variables for both plants and Orthoptera. These were therefore selected as landscape factors for further analysis (see Table $1)$.

\section{Local variables}

Local abiotic factors were measured for each plot. Organic carbon, total nitrogen and $\mathrm{pH}$ (in $\mathrm{KCl}$ solution) were measured from soil samples taken from the upper $10 \mathrm{~cm}$ in each plot (see Table 1). Slope and aspect were measured using a compass with clinometer (Recta DP6, Biel/Bienne, Switzerland). Aspect was analysed as folded aspect, expressing the 'southness' of a site by rescaling $0-360^{\circ}$ to $0-180^{\circ}$ in order to avoid the problems of using a circular measure of aspect (McCune and Keon 2009). We furthermore calculated mean vegetation height within the plot from five measurements (in the corners and the centre) using a tape measure, immediately after Orthoptera sampling.

\section{Determination of ecological traits}

Landscape composition has been found to have a large effect on richness and abundance of pollinators (e.g. Steffan-Dewenter et al. 2002; Heard et al. 2007). We therefore determined the pollen vector for each plant species based on information in Flora Indicativa (Landolt et al. 2010), or, if the species was not included, in the BiolFlor database (Klotz et al. 2002). If insects were among the pollen vectors then the species was classed as insect-pollinated. All others (including self and wind pollination syndromes) were classed as non-insect pollinated (Batáry et al. 2013). Mean seed mass for each species as an indicator of colonizing (lower seed mass) vs. competitive ability (higher seed mass; Lindborg et al. 2012) was taken from BiolFlor. Those with masses within the lower quartile of the range $(0.26 \mathrm{mg})$ were classed as light, and those within the upper quartile $(2.47 \mathrm{mg})$ as heavy. Character species of the phytosociological classes Festuco-Brometea and Molinio-Arrhenatheretea in Romania 
(following Sanda et al. 2008), i.e. the two typical classes for semi-natural dry and mesophilic grassland in the region (Oroian et al. 2007), were defined as characteristic grassland species (see Table S1, supplementary material). All others were termed non-characteristic species. Orthoptera species were classified according to their habitat preferences as either mesic or non-mesic (i.e. xerophilic or hygrophilic), based on habitat descriptions from Iorgu and Iorgu (2008). Species were additionally classified as mobile (holopter) or sedentary (mesopter and brachypter), based on wing length information from Harz $(1975,1969)$ and Kis $(1978,1976)$. For species with wing dimorphism, we used the most common form. In species where wing length differed between sexes, the mobility level of females was used, as these are usually associated with the higher reproductive costs and may be the more restrictive component in the abundance and distribution patterns of populations. Species and classifications are shown in Table S2, supplementary material. A summary of ecological traits used in the analysis is presented in Table 1.

\section{Statistical analysis}

All predictor variables showed linear relationships with the response variables. Predictor variables were tested for multicollinearity: out of every highly correlated pair (Spearman's rank correlation coefficient >0.6) the one that explained the highest variation for each response variable was retained for further analyses (Table 1). Generalized linear mixedeffects models (GLMM) using the lme4 package (Bates et al. 2014) for R (Version 3.0.2: R Core Team 2013) were used to analyse the effects of local and landscape variables on species richness of plants and Orthoptera and abundance of Orthoptera. The responses of each functional group were modelled separately. Pasture ID was included as a random effect in all models to account for potential pseudo-replication effects. Year was not included as a random factor as it did not improve the AIC value of any of the plant models. Poisson error distribution was used, except in the case of overdispersion, where negative binomial distributions were used. Full models were built for each response variable, including all noncorrelated predictor variables plus the interaction between landscape heterogeneity $\times$ disturbance level, and vegetation height $\times$ grassland $\%$ in the landscape as the most ecologically relevant interactions (for a summary of the variables see Table 1). Variables were then removed by backwards selection to achieve the optimal model based on AIC values. 
Table 1 Description of response variables, local and landscape predictor variables (fixed effects), and random effects used in the General Linear Mixed Models. Correlated variables (Spearman's rho>0.6) are indicated with the same letters.

\begin{tabular}{|c|c|c|}
\hline Variable & Description & Mean \pm SE \\
\hline \multicolumn{3}{|l|}{ Response } \\
\hline Plant species richness & Number of vascular plant species in $1000 \mathrm{~m}^{2}$ & $68.5 \pm 1.7$ \\
\hline $\begin{array}{l}\text { Characteristic / } \\
\text { non-characteristic }\end{array}$ & $\begin{array}{l}\text { Number of characteristic species for the classes Festuco- } \\
\text { Brometea and Molinio-Arrhenatheratea }(\mathrm{N}=56) / \\
\text { non-characteristic species }(\mathrm{N}=318)\end{array}$ & $\begin{array}{l}18.8 \pm 0.5 / \\
49.8 \pm 1.4\end{array}$ \\
\hline $\begin{array}{l}\text { Insect pollinated / } \\
\text { non-insect pollinated }\end{array}$ & $\begin{array}{l}\text { Number of insect pollinated }(\mathrm{N}=276) / \\
\text { non-insect pollinated plant species }(\mathrm{N}=98)\end{array}$ & $\begin{array}{l}50 \pm 1.4 / \\
18.5 \pm 0.5\end{array}$ \\
\hline $\begin{array}{l}\text { Light seeds / } \\
\text { heavy seeds }\end{array}$ & $\begin{array}{l}\text { Number of plant species with seeds } \leq 0.26 \mathrm{mg}(\mathrm{N}=94) / \\
\text { seeds }>2.47(\mathrm{~N}=93)\end{array}$ & $\begin{array}{l}12.7 \pm 0.4 / \\
14.8 \pm 0.6\end{array}$ \\
\hline Orthoptera species richness & Number of Orthoptera species in $1000 \mathrm{~m}^{2}$ & $4.5 \pm 0.3$ \\
\hline Orthoptera abundance & Number of Orthoptera individuals in $1000 \mathrm{~m}^{2}$ & $18.1 \pm 1.9$ \\
\hline $\begin{array}{l}\text { Mesic / } \\
\text { non-mesic }\end{array}$ & $\begin{array}{l}\text { Abundance of mesic Orthoptera species ( } \mathrm{N}=749 \text { indiv.) / } \\
\text { non-mesic ( } \mathrm{N}=606 \text { indiv.) }\end{array}$ & $\begin{array}{l}10.0 \pm 1.1 / \\
8.1 \pm 1.1\end{array}$ \\
\hline $\begin{array}{l}\text { Mobile / } \\
\text { sedentary }\end{array}$ & $\begin{array}{l}\text { Abundance of mobile }(\mathrm{N}=633) / \\
\text { sedentary Orthoptera species }(\mathrm{N}=722)\end{array}$ & $\begin{array}{l}8.44 \pm 1.0 / \\
9.6 \pm 1.3\end{array}$ \\
\hline \multicolumn{3}{|l|}{ Fixed local } \\
\hline $\mathrm{C}_{\text {org }}{ }^{\mathrm{a}}$ & Soil organic carbon content (Mmol/g dwt) & $4.0 \pm 0.1$ \\
\hline Disturbance & Disturbance level (low, medium or high) & \\
\hline $\mathrm{N}_{\text {tot }}{ }^{\mathrm{a}}$ & Soil total nitrogen content $(\%)$ & $0.4 \pm 0.0$ \\
\hline $\mathrm{pH}$ & Soil pH (measured in $\mathrm{KCl}$ ) & $5.4 \pm 0.1$ \\
\hline Slope & Slope of plot $\left(^{\circ}\right)$ & $5.0 \pm 0.3$ \\
\hline Southness & Folded aspect of plot $\left(1-180^{\circ}\right)$ & $68.9 \pm 5.6$ \\
\hline Vegetation height & Vegetation height during Orthoptera sampling & $20.5 \pm 1.1$ \\
\hline \multicolumn{3}{|l|}{ Fixed landscape } \\
\hline Grassland \% & Percentage grassland within a $2 \mathrm{~km}$ radius of plot & $37.8 \pm 1.3$ \\
\hline Landscape heterogeneity & Shannon diversity of land-cover within a $2 \mathrm{~km}$ radius of plot & $1.3 \pm 0.1$ \\
\hline \multicolumn{3}{|l|}{ Random } \\
\hline Pasture ID & Identity of pasture $(\mathrm{N}=25)$ & \\
\hline
\end{tabular}

Variation in species composition (plant species coverage values at $10 \mathrm{~m}^{2}$, and Orthoptera abundance at $1000 \mathrm{~m}^{2}$ ) was analysed by constrained ordination using redundancy analysis (RDA). Prior to analysis, rare plant species present in $<10 \%$ of plots were removed, and both plant and Orthoptera species matrices were Hellinger-transformed to reduce the effect of the most abundant species (Legendre and Gallagher 2001). Partial RDAs were performed, testing each variable separately as a constrained factor, plus the conditional variable pasture (to avoid 
pseudoreplication effects) and all remaining variables. Only predictor variables that were included in the GLMM final models were used in the RDA, in order to reduce the number of variables tested. Pseudo-F values with the corresponding $\mathrm{p}$ values were calculated by permutation tests based on 999 permutations. The analyses were carried out using the vegan package for R (version 2.15.3, Oksanen et al. 2013).

\section{Results}

Plants

A total of 374 vascular plant species were identified in the 75 plots, with a mean plant species richness of 68.5 species per $1000 \mathrm{~m} 2$ (34.6 per $10 \mathrm{~m} 2$ ). Total plant species richness per plot was positively related with soil nitrogen $(\mathrm{z}=2.11, \mathrm{p}=0.035)$, but the strongest relationship was with landscape heterogeneity, measured as Shannon diversity of land use types within a 2 $\mathrm{km}$ radius $(\mathrm{z}=3.10, \mathrm{p}=0.002$; Table 2 , Figure 1$)$. This positive relationship was highly significant for richness of characteristic grassland species $(\mathrm{z}=3.98, \mathrm{p}<0.001)$, but not significant for non-characteristic species, which were instead strongly dependent on soil $\mathrm{pH}(\mathrm{z}$ $=3.19, \mathrm{p}=0.001)$. Richness of insect and non-insect pollinated species showed similar positive relationships to landscape heterogeneity $(\mathrm{z}=2.67, \mathrm{p}=0.008$ and $\mathrm{z}=2.47, \mathrm{p}=0.013$, respectively). However, species with heavier seeds increased significantly with landscape heterogeneity $(z=3.03, p=0.003)$, whilst lighter-seeded species did not. Species with heavier seeds were also strongly positively related to $\mathrm{pH}(\mathrm{z}=3.42, \mathrm{p}<0.001)$, whilst those with lighter seeds were negatively related $(z=-2.18, p=0.029)$. There was a greater species richness of heavy seeded plants in low disturbance plots than in plots with high disturbance (z $=2.46, \mathrm{p}=0.014)$. The variation in plant species composition was only significantly linked to local factors: $\mathrm{pH}$, disturbance level and southness (Table 4; Figure S2, supplementary material). 
Table 2 Plant species richness summary table showing the results of the fixed effects in the final GLMMs. P-values below 0.05 are in bold.

\begin{tabular}{|c|c|c|c|c|}
\hline & Estimate & SE & $\mathrm{z}$ & $\mathrm{p}$ \\
\hline \multicolumn{5}{|l|}{ Plant species richness (all taxa) } \\
\hline Intercept & 3.28 & 0.18 & 18.17 & $<0.001$ \\
\hline Landscape heterogeneity & 0.36 & 0.12 & 3.10 & 0.002 \\
\hline $\mathrm{N}_{\text {tot }}$ & 0.36 & 0.17 & 2.11 & $\mathbf{0 . 0 3 5}$ \\
\hline $\mathrm{pH}$ & 0.04 & 0.02 & 1.71 & 0.087 \\
\hline Southness & $<0.01$ & $<0.01$ & 1.87 & 0.062 \\
\hline \multicolumn{5}{|l|}{ Characteristic grassland species } \\
\hline Intercept & 1.86 & 0.22 & 8.14 & $<0.001$ \\
\hline Landscape heterogeneity & 0.58 & 0.15 & 3.98 & $<0.001$ \\
\hline $\mathrm{N}_{\text {tot }}$ & 0.44 & 0.21 & 2.09 & 0.037 \\
\hline Southness & $<0.01$ & $<0.01$ & 1.56 & 0.119 \\
\hline \multicolumn{5}{|l|}{ Non-characteristic species } \\
\hline Intercept & 3.02 & 0.21 & 14.67 & 0.001 \\
\hline Landscape heterogeneity & 0.24 & 0.13 & 1.85 & 0.065 \\
\hline $\mathrm{N}_{\text {tot }}$ & 0.28 & 0.20 & 1.46 & 0.144 \\
\hline $\mathrm{pH}$ & 0.08 & 0.02 & 3.19 & 0.001 \\
\hline \multicolumn{5}{|l|}{ Insect pollinated species } \\
\hline Intercept & 2.78 & 0.21 & 13.44 & $<0.001$ \\
\hline Landscape heterogeneity & 0.35 & 0.13 & 2.67 & 0.008 \\
\hline $\mathrm{N}_{\text {tot }}$ & 0.54 & 0.19 & 2.87 & 0.004 \\
\hline $\mathrm{pH}$ & 0.06 & 0.03 & 2.24 & 0.025 \\
\hline Southness & $<0.01$ & $<0.01$ & 2.16 & $\mathbf{0 . 0 3 1}$ \\
\hline \multicolumn{5}{|l|}{ Non-insect pollinated species } \\
\hline Intercept & 2.58 & 0.22 & 11.88 & $<0.001$ \\
\hline $\mathrm{C}_{\text {org }}$ & -0.03 & 0.03 & -1.39 & 0.166 \\
\hline Landscape heterogeneity & 0.35 & 0.14 & 2.47 & 0.013 \\
\hline \multicolumn{5}{|l|}{ Species with light seeds } \\
\hline Intercept & 2.48 & 0.27 & 9.11 & $<0.001$ \\
\hline Landscape heterogeneity & 0.33 & 0.18 & 1.82 & 0.069 \\
\hline $\mathrm{pH}$ & -0.07 & 0.03 & -2.18 & 0.029 \\
\hline \multicolumn{5}{|l|}{ Species with heavy seeds } \\
\hline Intercept & 1.05 & 0.33 & 3.20 & 0.001 \\
\hline Disturbance: high $\rightarrow$ intermediate & 0.10 & 0.08 & 1.35 & 0.178 \\
\hline Disturbance: high $\rightarrow$ low & 0.20 & 0.08 & 2.46 & 0.014 \\
\hline Landscape heterogeneity & 0.61 & 0.20 & 3.03 & 0.003 \\
\hline $\mathrm{N}_{\text {tot }}$ & 0.70 & 0.35 & 1.99 & 0.047 \\
\hline $\mathrm{pH}$ & 0.11 & 0.03 & 3.42 & $<0.001$ \\
\hline
\end{tabular}


Table 3 Results of partial RDAs to analyse the effect of local and landscape variables on plant and Orthoptera species composition.

\begin{tabular}{llll}
\hline & Variation (\%) & pseudo-F & $\mathrm{p}$ \\
\hline Plants & & & \\
$\quad$ Disturbance & 3.0 & 1.64 & $\mathbf{0 . 0 0 2}$ \\
Landscape heterogeneity & 0.9 & 0.96 & 0.510 \\
$\mathrm{~N}_{\text {tot }}$ & 1.0 & 1.07 & 0.330 \\
$\mathrm{pH}$ & 3.4 & 3.67 & $\mathbf{0 . 0 0 1}$ \\
$\quad$ Southness & 1.6 & 1.75 & $\mathbf{0 . 0 2 1}$ \\
\hline Orthoptera & & & \\
Grassland \% & 0.8 & 0.76 & 0.669 \\
Grassland \% $\times$ Vegetation height & 2.0 & 2.05 & $\mathbf{0 . 0 2 5}$ \\
Southness & 3.2 & 3.25 & $\mathbf{0 . 0 0 2}$ \\
$\quad$ Vegetation height & 2.0 & 2.01 & $\mathbf{0 . 0 3 1}$ \\
\hline
\end{tabular}

\section{Orthoptera}

1355 adult Orthoptera individuals were caught in the plots and identified to 28 species (approximately 30\% of the Orthoptera species recorded for the Transylvanian plateau ecoregion according to Iorgu et al. 2008). Overall species richness as well as the abundance of most Orthoptera groups showed a positive relationship with grassland \% in the landscape (Figure 1), as well as a negative relationship with local plant species richness (Table 3). Mobile species reacted to both local and landscape factors more strongly than sedentary species, which showed no relationship with any of the tested variables. The abundance of non-mesic species was additionally strongly positively related to southness of plot exposition $(\mathrm{z}=3.42, \mathrm{p}=0.001)$ and landscape heterogeneity $(\mathrm{z}=2.23, \mathrm{p}=0.026)$, while mesic species did not show any relationship with these two factors. Orthoptera community composition varied significantly along gradients of southness and vegetation height, as well as with the interaction between vegetation height and grassland \% in the landscape (Table 4; Figure S3, supplementary material). 
Table 4 Orthoptera species richness summary table showing the results of the fixed effects in the final GLMMs. P-values below 0.05 are in bold.

\begin{tabular}{|c|c|c|c|c|}
\hline & Estimate & SE & $\mathrm{z}$ & $\mathrm{p}$ \\
\hline \multicolumn{5}{|l|}{ Orthoptera species richness } \\
\hline Intercept & 1.34 & 0.34 & 3.96 & $<0.001$ \\
\hline Grassland \% & 0.01 & 0.01 & 2.05 & 0.040 \\
\hline Plant species richness & -0.01 & $<0.01$ & -1.80 & 0.072 \\
\hline Vegetation height & 0.01 & 0.01 & 2.10 & 0.040 \\
\hline \multicolumn{5}{|l|}{ Orthoptera abundance } \\
\hline Intercept & 2.73 & 0.52 & 5.25 & $<0.001$ \\
\hline Grassland \% & 0.03 & 0.01 & 3.30 & 0.001 \\
\hline Plant species richness & -0.02 & 0.01 & -2.74 & 0.006 \\
\hline Southness & $<0.01$ & $<0.01$ & 2.21 & $\mathbf{0 . 0 2 7}$ \\
\hline \multicolumn{5}{|l|}{ Mesic species } \\
\hline Intercept & 2.26 & 0.61 & 3.72 & $<0.001$ \\
\hline Grassland \% & 0.03 & 0.01 & 3.35 & 0.001 \\
\hline Plant species richness & -0.02 & 0.01 & -2.50 & 0.012 \\
\hline \multicolumn{5}{|l|}{ Non-mesic species } \\
\hline Intercept & -0.69 & 1.21 & -0.58 & 0.565 \\
\hline Grassland \% & 0.04 & 0.01 & 2.98 & 0.003 \\
\hline Landscape heterogeneity & 1.70 & 0.76 & 2.23 & 0.026 \\
\hline Plant species richness & -0.02 & 0.01 & -2.50 & 0.013 \\
\hline Southness & 0.01 & $<0.01$ & 3.42 & 0.001 \\
\hline \multicolumn{5}{|l|}{ Mobile species } \\
\hline Intercept & 1.44 & 0.63 & 2.28 & 0.023 \\
\hline Grassland \% & 0.03 & 0.01 & 3.04 & 0.002 \\
\hline Plant species richness & -0.02 & 0.01 & -2.89 & 0.004 \\
\hline Southness & 0.01 & $<0.01$ & 2.95 & 0.003 \\
\hline Vegetation height & 0.03 & 0.01 & 2.48 & 0.013 \\
\hline \multicolumn{5}{|l|}{ Sedentary species } \\
\hline Intercept & 1.63 & 0.17 & 9.63 & $<0.001$ \\
\hline
\end{tabular}



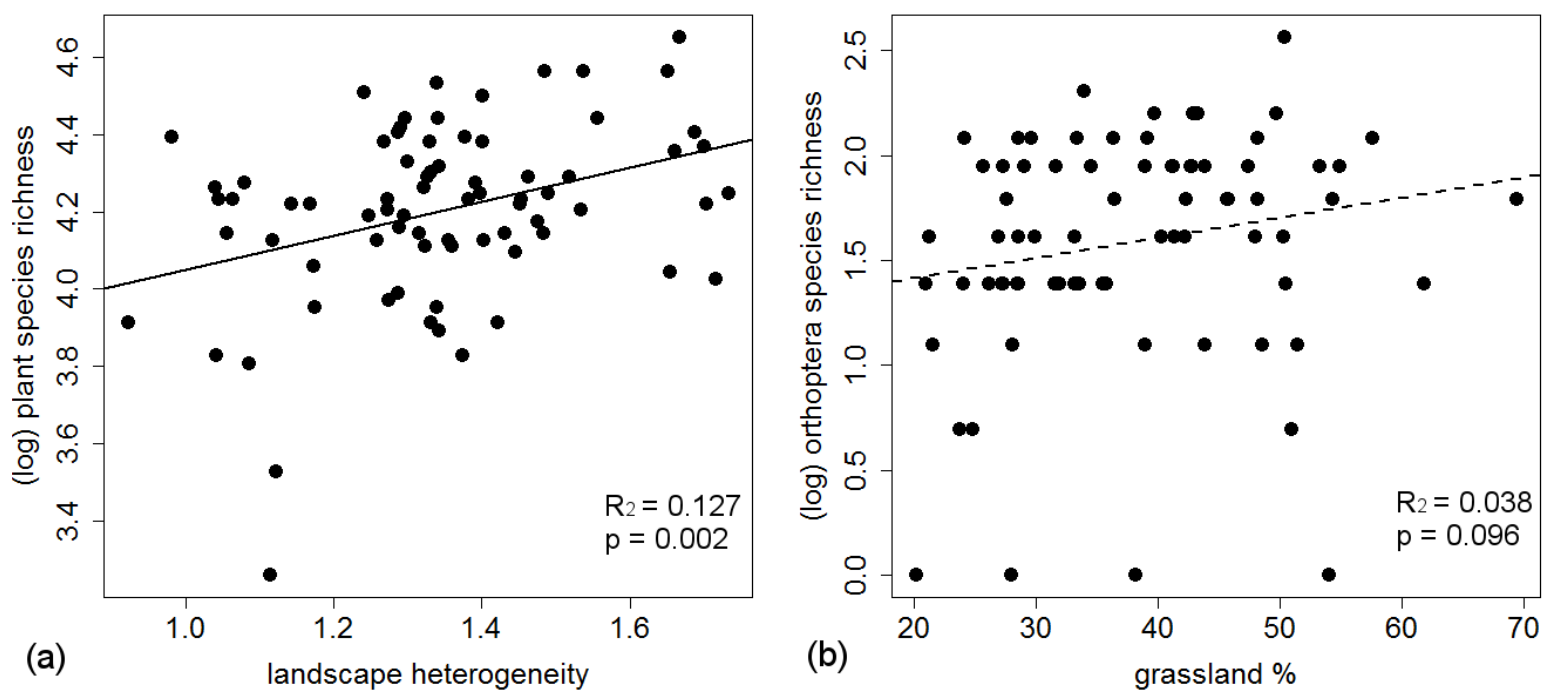

Figure 1 Simple regression of (a) total vascular plant species richness against landscape heterogeneity (Shannon index of land-cover types) and (b) Orthoptera species richness and percentage grassland in a $2 \mathrm{~km}$ radius. Dashed line $=$ non-significant trend.

\section{Discussion}

\section{Local effects}

Plant and Orthoptera species richness and composition in the studied semi-natural grasslands was significantly affected by local habitat conditions. In the case of plants, microclimate (southness, disturbance by grazing) and soil (nitrogen, $\mathrm{pH}$ ), and in the case of Orthoptera, microclimate and habitat structure (southness, vegetation height) exerted significant effects, which is in line with the abundant literature on grassland ecology (e.g. Chytrý et al. 2003; Becker and Brändel 2007; Schirmel et al. 2010; Essl and Dirnböck 2012; Weiss et al. 2013). The positive effect of soil nitrogen content on overall plant species richness is somewhat unexpected, as higher $\mathrm{N}$ supply is typically associated with the dominance of more competitive species (Stevens et al. 2010). However, the relationship between $\mathrm{N}$ and plant species richness is humpbacked rather than linear at low levels of $\mathrm{N}$ : Janssens et al. (1998) determined an optimum of $0.5 \%$ total $\mathrm{N}$ in dry soil, which is higher than the average value for the plots in this study. Such low nutrient grasslands are now rare in Europe due to widespread agricultural intensification and atmospheric nitrogen deposition, especially in the north and west (Stoate et al. 2009). 
Grazing disturbance and soil $\mathrm{pH}$ did not significantly affect overall plant species richness within plots, but were important factors affecting community composition and therefore turnover between plots. For example, plants with heavier seeds were more prevalent in plots with high $\mathrm{pH}$ and lower levels of disturbance, whilst plants with lighter seeds were more prevalent on low $\mathrm{pH}$ soils and did not vary with disturbance. This supports the hypothesis that species with larger seeds are more competitive and adapted for local persistence (e.g. Jakobsson and Eriksson 2000). This enables them to survive well in patches of high species richness (for example linked to high $\mathrm{pH}$ ) and undisturbed succession, where competition for resources is high. The results are, however, inconclusive about the importance of light seeds in colonising disturbed patches.

Many studies have found a positive relationship between plant and Orthoptera species richness in semi-natural grassland, probably because both groups benefit from the same environmental factors (Essl and Dirnböck 2012; Kati et al. 2012; Kovács-Hostyánszki et al. 2011; Marini et al. 2008; Sauberer et al. 2004). In contrast, we found a negative relationship between the two groups. Direct effects between the two groups are unlikely, as despite being mainly herbivores, most Orthoptera species are not specialised on particular host species (Joern 1979). The negative relationship could therefore be indicative of indirect effects. For example, high plant diversity may be more likely to occur with low proportions of bare ground, which is an important resource for oviposition in many Orthoptera species (e.g. Fartmann et al. 2012; Weiss et al. 2013). Generally, the volume of food resources, as well as the type of microclimate and structural complexity that may support species with contrasting behavioural habits, are important local factors determining species richness and composition (Schirmel et al. 2010), as confirmed by the significant effects of vegetation height in this study. Southness was also a significant factor for Orthoptera community composition: nonmesic species (the majority of which were xerophilic species) were more abundant in southfacing sites, presumably due to their preference for drier and warmer conditions.

\section{Landscape effects}

Both taxonomic groups provided strong evidence for the influence of the wider surrounding habitats on local species-rich communities: plant species richness showed a highly significant positive relationship with landscape heterogeneity of land use types, whilst Orthoptera species richness was positively related with the amount of grassland in the landscape. The relationships of both plant and Orthoptera to landscape factors is in contrast to the findings of 
Marini et al. (2008), who found no effect of landscape factors on plants, but a significant effect on Orthoptera. Generally, the findings in the literature regarding landscape effects on grassland plant communities are mixed, providing both evidence for (e.g. Söderstrom et al. 2001; Öckinger et al. 2012; Reitalu et al. 2012; Schmucki et al. 2013; Janišová et al. 2013) and against (e.g. Dauber et al. 2003; Krauss et al. 2004; Löbel et al. 2006; Öster et al. 2007; Jonasson et al. 2011). This may be a result of the overriding effects of local factors in some of the investigated grasslands (Dauber et al. 2003; Marini et al. 2008), which would not have been the case in the low-nutrient semi-natural grasslands in this study. However, relationships have also been found to be stronger for historical landscape configurations than for modern landscapes, due to the relatively slow reactions of plant communities (Helm et al. 2006; Lindborg and Eriksson 2004). It is therefore possible that the landscapes in Southern Transylvania have, despite large changes in agriculture in Romania as a whole during the 20th century, remained essentially more similar to the historical situation than in some of the previously mentioned studies. Both historical and current ecological processes involved in landscape effects on local communities are complex, and multiple potential mechanisms have been proposed whereby landscape context may influence plot-scale communities (for an overview see e.g. Tscharntke et al. 2012), several of which are discussed in the following.

\section{i) Landscape habitat amount}

Local species richness may increase with the total amount of habitat in the surrounding landscape, independent of individual patch size and isolation (Fahrig 2013). This is supported by the results for Orthoptera in this study, the species richness and abundance of which increased with the proportion of grassland in the surrounding landscape. Populations may therefore benefit from a higher immigration probability with increasing grassland habitat in the landscape regardless of its configuration, perhaps as the generally high proportion of semi-natural vegetation in the study region allows easy movement between patches. Grassland in the study area is furthermore not associated with high mortality risks (e.g. from mowing), as was suggested by Marini et al. (2008) to explain the negative effect of grassland proportion on Orthoptera species richness they found.

ii) Landscape species pool 
Local plant species richness can also be moderated by the landscape-wide species pool. Increasing landscape heterogeneity, i.e. a greater richness and evenness of different habitat types, causes an increase in the potential pool of species available to colonise local sites, provided connectivity is adequate (Tscharntke et al. 2012). This appears to be the case for overall plant species richness in this study, supporting the findings of Janišová et al. (2013), which showed that plant species richness in Slovakian grasslands increased with increasing diversity of surrounding semi-natural habitats. Particularly the characteristic grassland plant species in this study reacted strongly to landscape heterogeneity. Although they form the basis of typical unfertilized mesic and dry grasslands in the area, the majority of these characteristic species are not restricted only to these habitats. This suggests that a variety of different (seminatural) vegetation types, or the ecotones between them, provide a range of habitat niches that support typical grassland species, potentially acting as sources for recolonization after disturbance. Grassland specialists have also been found to increase with increasing forest cover in the landscape (Cousins and Aggemyr 2008), supporting the assumption that even these sensitive plant species can exist under a range of habitat and ecotonal conditions.

\section{iii) Landscape moderation of species traits}

The landscape context may furthermore moderate species trait selection at the plot scale through its influence on ecological interactions (Tscharntke et al. 2012). Whilst neither of the landscape factors significantly affected the community composition, they were significantly related to the variation in functional groups. For example, heavy-seeded (but not light-seeded) plant species occurred more frequently in more heterogeneous landscapes. Lower seed mass has been found in previous studies to be related to sensitivity to habitat isolation, probably due to the reliance of these species on dispersal (reviewed in Lindborg et al. 2012). In the generally well connected grasslands in this study, in contrast, heavier seeded plants may have had a competitive advantage under the higher species richness associated with increasing landscape heterogeneity, due to the greater competitive ability of their seedlings.

Regarding pollination effects, both insect and non-insect pollinated species reacted positively to landscape heterogeneity, despite the fact that pollinators are usually more prevalent in heterogeneous landscapes with higher proportions of semi-natural habitat (Steffan-Dewenter et al. 2002; Heard et al. 2007; Holzschuh et al. 2010). However, other studies on richness of insect pollinated plants in more intensified landscapes also found no landscape effects (Batáry 
et al. 2013; Power et al. 2012), suggesting that pollination effects may often be mediated by other factors.

For Orthoptera, landscape heterogeneity had a positive effect on non-mesic species, suggesting that these species benefit from the greater range of environmental conditions found in different habitat types. Within the Orthoptera, previous studies have found that mobile species were more strongly (positively) related to habitat diversity than sedentary species, and increasing mobility is thought to facilitate exchange between habitat patches (Marini et al. 2010). In this study, more mobile species were also more sensitive to landscape effects, but reacted positively to grassland percentage rather than habitat diversity.

\section{Implications for conservation policy}

Management methods affecting conditions at the local (field) scale are currently targeted in the EU by measures such as cross-compliance and agri-environment schemes, but landscape effects are rarely considered in the designs of such measures (but see e.g. Verhulst et al. 2006). Nevertheless, we found landscape composition to be a significant driver of plant and Orthoptera species richness and abundance at the scale of a $2 \mathrm{~km}$ radius from the sampling plot. This area is several orders of magnitude larger than the average holding size in the region, meaning that conservation measures for species-rich grasslands need to ideally target groups of, rather than single, farmers. The effect of landscape heterogeneity was positive for plant species richness in the studied grasslands, and particularly for that of characteristic grassland species, potentially through enhancement of the available species pool. Homogenization of these landscapes, through abandonment, intensification or land-use change, is therefore likely to have a detrimental effect on grassland plant diversity, even if current low-intensity grassland management is maintained.

In our study, grassland habitat availability in the landscape had a positive effect on species richness and abundance of Orthoptera. Destruction of grassland habitat in the landscape, for example by conversion to arable fields, is therefore likely to be an important threat for this group. The different ecological responses of the two taxonomic groups highlight the fact that conservation management targeting one species or group may be detrimental for another (see e.g. Konvička et al. 2007). The use of one taxonomic group as a proxy or surrogate for another may therefore be unhelpful (cf. Kati et al. 2012). Even within taxonomic groups, different species or communities may react differently, as was found e.g. by Janišová et al. 
(2013) in the responses of mesophilic or xerophilic vegetation types to landscape structure. Ideally, conservation approaches should therefore aim to promote a range of low-intensity land use practices in order to support a variety of landscape types. This is particularly important in eastern European countries such as Romania, where many such species-rich landscapes still exist but are threatened by agricultural intensification and abandonment (Stoate et al. 2009). The disparity between the findings here and those in the literature, which are mostly from intensified landscapes in western Europe, further underline the need for more regionally specific information on species responses to local and landscape factors to inform context-appropriate conservation approaches.

\section{Conclusions}

Both local and landscape factors were found to affect plant and Orthoptera communities in semi-natural grasslands in Southern Transylvania, suggesting that conservation approaches focussing on these species-rich communities need to consider larger areas than just the field scale. However, the two groups responded to different landscape factors, underlining the fact that measures aimed at one species or taxonomic group will not have beneficial effects on biodiversity in general. This is especially the case in species-rich areas such as the cultural landscapes of Eastern Europe. Here, pressure on species from intensification and abandonment is growing, but the existence of large populations of multiple target species creates conflicts when prescribing management measures. Supporting the continuation of lowintensity practices with measures appropriate for the region would be an important step towards protecting these grasslands. Further studies on landscape effects in such areas involving more species groups would also help to better understand the mechanisms involved and more accurately predict the outcomes of future changes in land use.

\section{Acknowledgements}

The authors gratefully acknowledge support from Fundația ADEPT Transilvania in carrying out this study. L.S. was supported by a grant from the Lower Saxony Ministry of Science and Culture, P.B. was funded by the German Research Foundation (DFG BA 4438/1-1). Many thanks also to Joern Fischer, Jan Hanspach, Tibor Hartel and Henrik von Wehrden for providing helpful advice. 


\section{References}

Aavik, T., Augenstein, I., Bailey, D., Herzog, F., Zobel, M. \& Liira, J. (2008) What is the role of local landscape structure in the vegetation composition of field boundaries? Applied Vegetation Science, 11, 375-386.

Báldi, A. \& Batáry, P. (2011) Spatial heterogeneity and farmland birds: different perspectives in Western and Eastern Europe. Ibis, 153, 875-876.

Batáry, P., Báldi, A., Kleijn, D. \& Tscharntke, T. (2010) Landscape-moderated biodiversity effects of agri-environmental management: a meta-analysis. Proceedings of the Royal Society B: Biological Sciences, 278, 1894-1902.

Batáry, P., Báldi, A., Szél, G., Podlussány, A., Rozner, I. \& Erdős, S. (2007a) Responses of grassland specialist and generalist beetles to management and landscape complexity. Diversity and Distributions, 13, 196-202.

Batáry, P., Orci, K.M., Báldi, A., Kleijn, D., Kisbenedek, T. \& Erdős, S. (2007b) Effects of local and landscape scale and cattle grazing intensity on Orthoptera assemblages of the Hungarian Great Plain. Basic and Applied Ecology, 8, 280-290.

Batáry, P., Sutcliffe, L.M.E., Dormann, C.F. \& Tscharntke, T. (2013) Organic Farming Favours Insect-Pollinated over Non-Insect Pollinated Forbs in Meadows and Wheat Fields. PloS One, 8, e54818.

Bates, D., Maechler, M. \& Bolker, B.M. (2012) lme4: Linear mixed-effects models using S4 classes.

Becker, T. \& Brändel, M. (2007) Vegetation-Environment Relationships in a Heavy MetalDry Grassland Complex. Folia Geobotanica, 42, 11-28.

Bullock, J.M., Jefferson, R.G., Blackstock, T.H., Pakeman, R.J., Emmett, B.A., Pywell, R.J., Grime, J.P. \& Silvertown, J. (2011) Semi-natural Grasslands. The UK National Ecosystem Assessment Technical Report pp. 161-196. UNEP-WCMC, Cambridge.

Chytrý, M., Tichý, L. \& Role, J. (2003) Local and Regional Patterns of Species Richness in Central European Vegetation Types along the $\mathrm{pH} /$ Calcium Gradient. Folia Geobotanica, 38, 429-442.

Concepción, E.D., Díaz, M. \& Baquero, R.A. (2008) Effects of landscape complexity on the ecological effectiveness of agri-environment schemes. Landscape Ecology, 23, 135-148.

Cousins, S.A.O. \& Aggemyr, E. (2008) The influence of field shape, area and surrounding landscape on plant species richness in grazed ex-fields. Biological Conservation, 141, $126-135$.

Dauber J, Hirsch M, Simmering D, Waldhardt R, Otte A, Wolters V (2003) Landscape structure as an indicator of biodiversity: matrix effects on species richness. Agriculture, Ecosystems \& Environment 98, 321-329.

EEA. (2010) EU 2010 Biodiversity Baseline. European Environment Agency, Copenhagen. 
Ellenberg, H. \& Leuschner, C. (2010) Vegetation Mitteleuropas Mit Den Alpen [Vegetation ecology of Central Europe]. Verlag Eugen Ulmer, Stuttgart, Germany.

Essl, F. \& Dirnböck, T. (2012) What determines Orthoptera species distribution and richness in temperate semi-natural dry grassland remnants? Biodiversity and Conservation, 21, $2525-2537$.

Fahrig, L. (2013) Rethinking patch size and isolation effects: the habitat amount hypothesis. Journal of Biogeography, 40, 1649-1663.

Fahrig, L., Baudry, J., Brotons, L., Burel, F.G., Crist, T.O., Fuller, R.J., Sirami, C., Siriwardena, G.M. \& Martin, J.-L. (2010) Functional landscape heterogeneity and animal biodiversity in agricultural landscapes. Ecology Letters, 14, 101-112.

Fartmann T., Krämer B., Stelzner F., Poniatowski D. (2012) Orthoptera as ecological indicators for succession in steppe grassland. Ecological Indicators 20, 337-344.

Fuentes-Montemayor, E., Goulson, D. \& Park, K.J. (2011) Pipistrelle bats and their prey do not benefit from four widely applied agri-environment management prescriptions. Biological Conservation, 144, 2233-2246.

Gardiner T., Hill J., Chesmore D. (2005) Review of the Methods Frequently Used to Estimate the Abundance of Orthoptera in Grassland Ecosystems. Journal of Insect Conservation 9, 151-173. doi: 10.1007/s10841-005-2854-1

Harz, K. (1969) Die Orthopteren Europas 1. Dr. W. Junk Publishers, The Hague, the Netherlands.

Harz. (1975) Die Orthopteren Europas 2. Dr. W. Junk Publishers, The Hague, the Netherlands.

Heard, M.S., Carvell, C., Carreck, N.L., Rothery, P., Osborne, J.L. \& Bourke, A.F.G. (2007) Landscape context not patch size determines bumble-bee density on flower mixtures sown for agri-environment schemes. Biology Letters, 3, 638-641.

Helm, A., Hanski, I. \& Pärtel, M. (2006) Slow response of plant species richness to habitat loss and fragmentation. Ecology Letters, 9, 72-77.

Hiron, M., Berg, Å., Eggers, S., Josefsson, J. \& Pärt, T. (2013) Bird diversity relates to agrienvironment schemes at local and landscape level in intensive farmland. Agriculture, Ecosystems \& Environment, 176, 9-16.

Holzschuh, A., Steffan-dewenter, I. \& Tscharntke, T. (2010) How do landscape composition and configuration, organic farming and fallow strips affect the diversity of bees, wasps and their parasitoids? Journal of Animal Ecology, 491-500.

Iorgu, I.S. \& Iorgu, E.I. (2008) Bush-Crickets, Crickets and Grasshoppers from Moldavia (Romania). PIM, Iasi, Romania. 
Iorgu, I.S., Pisica, E., Pais, L., Lupu, G. \& Iusan, C. (2008) Checklist of Romanian Orthoptera (Insecta) and their distribution by eco-regions. Travaux du Muséum National d'Histoire Naturelle «Grigore Antipa», 51, 119-135.

Jakobsson, A. \& Eriksson, O. (2000) A comparative study of seed number, seed size, seedling size and recruitment in grassland plants. Oikos, 88, 494-502.

Janišová, M., Michalcová, D., Bacaro, G. \& Ghisla, A. (in press) Landscape effects on diversity of semi-natural grasslands. Agriculture, Ecosystems \& Environment, http://dx.doi.org/10.1016/j.agee.2013.05.022.

Janssens, F., Peeters, A., Tallowin, J.R.B., Bakker, J.P., Bekker, R.M., Fillat, F. \& Oomes, M.J.M. (1998) Relationship between soil chemical factors and grassland diversity. Plant and Soil, 202, 69-78.

Joern A. (1979) Feeding patterns in grasshoppers (Orthoptera: Acrididae): Factors Influencing Diet Specialization. Oecologia 38, 325-347.

Jonason, D., Andersson, G.K.S., Ockinger, E., Rundlöf, M., Smith, H.G. \& Bengtsson, J. (2011) Assessing the effect of the time since transition to organic farming on plants and butterflies. Journal of Applied Ecology, 48, 543-550.

Kati, V., Zografou, K., Tzirkalli, E., Chitos, T. \& Willemse, L. (2012) Butterfly and grasshopper diversity patterns in humid Mediterranean grasslands: the roles of disturbance and environmental factors. Journal of Insect Conservation, 16, 807-818.

Kis, B. (1976) Cheie pentru determinarea Orthopterelor din Romania Partea I. Subordinul Ensifera [Key for the identification of the Orthoptera of Romania Part I]. Muzeul Brukenthal Stiintele Naturii - Studii si Comunicari, 20, 123-166.

Kis, B. (1978) Cheie pentru determinarea Orthopterelor din Romania Partea II. Subordinul Caelifera [Key for the identification of the Orthoptera of Romania Part II. Suborder Caelifera]. Muzeul Brukenthal Stiintele Naturii - Studii si Comunicari, 22, 233-276.

Klotz, S., Kühn, I. \& Durka, W. (2002) BIOLFLOR - Eine Datenbank zu biologischökologischen Merkmalen der Gefäßpflanzen in Deutschland [BIOLFLOR - A database of biological-ecological characteristics of the vascular plants in Germany]. Schriftenreihe für Vegetationskunde, 38.

Konvička, M., Benes, J., Cizek, O., Kopecek, F., Konvička, O. \& Vitaz, L. (2007) How too much care kills species: Grassland reserves, agri-environmental schemes and extinction of Colias myrmidone (Lepidoptera: Pieridae) from its former stronghold. Journal of Insect Conservation, 12, 519-525.

Koper, N. \& Nudds, T.D. (2011) Progress in Research on Grassland Bird Conservation and Ecology. Avian Conservation and Ecology, 6, 6.

Körösi, Á., Batáry, P., Orosz, A., Rédei, D. \& Báldi, A. (2012) Effects of grazing, vegetation structure and landscape complexity on grassland leafhoppers (Hemiptera: Auchenorrhyncha) and true bugs (Hemiptera: Heteroptera) in Hungary. Insect Conservation and Diversity, 5, 57-66. 
Kovács-Hostyánszki, A., Kőrösi, Á., Orci, K.M., Batáry, P. \& Báldi, A. (2011) Set-aside promotes insect and plant diversity in a Central European country. Agriculture, Ecosystems \& Environment, 141, 296-301.

Krauss, J., Bommarco, R., Guardiola, M., Heikkinen, R.K., Helm, A., Kuussaari, M., Lindborg, R., Öckinger, E., Pärtel, M., Pino, J., Pöyry, J., Raatikainen, K.M., Sang, A., Stefanescu, C., Teder, T., Zobel, M. \& Steffan-Dewenter, I. (2010) Habitat fragmentation causes immediate and time-delayed biodiversity loss at different trophic levels. Ecology Letters, 13, 597-605.

Krauss J., Klein A.-M., Steffan-Dewenter I., Tscharntke T. (2004) Effects of habitat area, isolation, and landscape diversity on plant species richness of calcareous grasslands. Biodiversity and Conservation 13,1427-1439.

Landolt, E., Bäumler, B., Erhardt, A., Hegg, O., Klötzli, F., Lämmler, W., Nobis, M. \& Rudmann-Maurer, K Schweingruber, F; Theurillat, J.P; Urmi, E; Vust, M; Wohlgemuth, T. (2010) Flora Indicativa: Ökologische Zeigerwerte Und Biologische Kennzeichen Zur Flora Der Schweiz Und Der Alpen [Ecological Indicator Values and Biological Attributes of the Flora of Switzerland and the Alps], 1st ed. Haupt, Bern, Switzerland.

Legendre, P. \& Gallagher, E. (2001) Ecologically meaningful transformations for ordination of species data. Oecologia, 129, 271-280.

Lindborg, R. \& Eriksson, O. (2004) Historical landscape connectivity affects present plant species diversity. Ecology, 85, 1840-1845.

Lindborg R., Helm A., Bommarco R., Heikkinen R.K., Kühn I., Pykälä J., \& Pärtel M. (2012) Effect of habitat area and isolation on plant trait distribution in European forests and grasslands. Ecography 35, 356-363.

Löbel S., Dengler J., Hobohm C. (2006) Species richness of vascular plants, bryophytes and lichens in dry grasslands: the effects of environment, landscape structure and competition. Folia Geobotanica 41,377-393.

Marini, L., Bommarco, R., Fontana, P. \& Battisti, A. (2010) Disentangling effects of habitat diversity and area on orthopteran species with contrasting mobility. Biological Conservation, 143, 2164-2171.

Marini, L., Fontana, P., Scotton, M. \& Klimek, S. (2008) Vascular plant and Orthoptera diversity in relation to grassland management and landscape composition in the European Alps. Journal of Applied Ecology, 45, 361-370.

McCune, B. \& Keon, D. (2009) Equations for potential annual direct incident radiation and heat load. Journal of Vegetation Science, 13, 603-606.

McKenzie, A.J., Emery, S.B., Franks, J.R. \& Whittingham, M.J. (2013) Landscape-scale conservation: collaborative agri-environment schemes could benefit both biodiversity and ecosystem services, but will farmers be willing to participate? Journal of Applied Ecology, 50, 1274-1280. 
Öckinger, E., Lindborg, R., Sjödin, N.E. \& Bommarco, R. (2012) Landscape matrix modifies richness of plants and insects in grassland fragments. Ecography, 35, 259-267.

Oksanen, J., Blanchet, F.G., Kindt, R., Legendre, P., Minchin, P.R., O’Hara, R.B., Simpson, G.L., Solymos, P., Henry, M., Stevens, H. \& Wagner, H. (2013) vegan: Community Ecology Package. R package version 2.0-6.

Oroian, S., Hiriţiu, M. \& Curticăpean, M. (2007) The xero-mezophylic and xerophylic grasslands of festuco-brometea class in the Sighişoara - Tarnava mare potential Natura 2000 site (Transylvania, Romania). Transylvanian Review of Systematic Ecological Research, 3, 83-126.

Öster M., Cousins S.A.O., Eriksson O. (2007) Size and heterogeneity rather than landscape context determine plant species richness in semi-natural grasslands. Journal of Vegetation Science 18,859-868.

Pärtel, M., Kalamees, R., Reier, Ü., Tuvi, E.-L., Roosaluste, E., Vellak, A. \& Zobel, M. (2005) Grouping and prioritization of vascular plant species for conservation: combining natural rarity and management need. Biological Conservation, 123, 271-278.

Poschlod, P. \& Wallis De Vries, M.F. (2002) The historical and socioeconomic perspective of calcareous grasslands-lessons from the distant and recent past. Biological Conservation, 104, 361-376.

Power, E.F., Kelly, D.L. \& Stout, J.C. (2012) Organic farming and landscape structure: effects on insect-pollinated plant diversity in intensively managed grasslands. PloS One, 7, e38073.

Prevedello, J.A. \& Vieira, M.V. (2010) Does the type of matrix matter? A quantitative review of the evidence. Biodiversity and Conservation, 19, 1205-1223.

Quantum GIS Development Team. (2013) Quantum GIS Geographic Information System. Open Source Geospatial Foundation Project.

R Core Team (2013) R: A language and environment for statistical computing. R Foundation for Statistical Computing.

Raatikainen, K.M., Heikkinen, R.K. \& Luoto, M. (2008) Relative importance of habitat area, connectivity, management and local factors for vascular plants: spring ephemerals in boreal semi-natural grasslands. Biodiversity and Conservation, 18, 1067-1085.

Reif, J., Böhning-Gaese, K., Flade, M., Schwarz, J. \& Schwager, M. (2011) Population trends of birds across the iron curtain: Brain matters. Biological Conservation, 144, 2524-2533.

Reitalu, T., Purschke, O., Johansson, L.J., Hall, K., Sykes, M.T. \& Prentice, H.C. (2012) Responses of grassland species richness to local and landscape factors depend on spatial scale and habitat specialization. Journal of Vegetation Science, 23, 41-51.

Rösch, V., Tscharntke, T., Scherber, C. \& Batáry, P. (2013) Landscape composition, connectivity and fragment size drive effects of grassland fragmentation on insect communities. Journal of Applied Ecology, 50, 387-394. 
Sanda, V., Öllerer, K. \& Burescu, P. (2008) Fitocenozele Din România [The phytocoenoses of Romania]. Ars Docendi, Bucharest.

Sauberer, N., Zulka, K.P., Abensperg-Traun, M., Berg, H.-M., Bieringer, G., Milasowszky, N., Moser, D., Plutzar, C., Pollheimer, M., Storch, C., Tröstl, R., Zechmeister, H. \& Grabherr, G. (2004) Surrogate taxa for biodiversity in agricultural landscapes of eastern Austria. Biological Conservation, 117, 181-190.

Schirmel, J., Mantilla-Contreras, J., Blindow, I. \& Fartmann, T. (2010) Impacts of succession and grass encroachment on heathland Orthoptera. Journal of Insect Conservation, 15, 633-642.

Schmucki, R., Reimark, J., Lindborg, R. \& Cousins, S.A.O. (2012). Landscape context and management regime structure plant diversity in grassland communities. Journal of Ecology, 100, 1164-1173.

Söderström B., Svensson B., Vessby K., Glimskär A. (2001) Plants, insects and birds in seminatural pastures in relation to local habitat and landscape factors. Biodiversity and Conservation 10,1839-1863.

Speta, E. \& Rákosy, L. (2010) Wildpflanzen Siebenbürgens [The wild plants of Transylvania], 1st ed. Plöchl Druck GmbH, Freistadt, Austria.

Steffan-Dewenter, I., Münzenberg, U., Bürger, C., Thies, C. \& Tscharntke, T. (2002) Scaledependent effects of landscape context on three pollinator guilds. Ecology, 83, 14211432 .

Stevens, C.J., Duprè, C., Dorland, E., Gaudnik, C., Gowing, D.J.G., Bleeker, A., Diekmann, M., Alard, D., Bobbink, R., Fowler, D., Corcket, E., Mountford, J.O., Vandvik, V., Aarrestad, P.A., Muller, S. \& Dise, N.B. (2010) Nitrogen deposition threatens species richness of grasslands across Europe. Environmental Pollution, 158, 2940-2945.

Stoate C., Báldi A., Beja P., Boatman N.D., Herzon I., van Doorn A., de Snoo G.R., Rakosy L., Ramwell C. (2009) Ecological impacts of early 21st century agricultural change in Europe - A review. Journal of Environmental Management 91, 22-46.

Strijker, D. (2005) Marginal lands in Europe - causes of decline. Basic and Applied Ecology, 6, 99-106.

Szymkowiak J., Skierczyński M., Kuczyński L. (2014) Are buntings good indicators of agricultural intensity? Agriculture, Ecosystems \& Environment 188, 192-197.

Tryjanowski, P., Hartel, T., Báldi, A., Szymański, P., Tobolka, M., Herzon, I., Goławski, A., Konvička, M., Hromada, M., Jerzak, L., Kujawa, K., Lenda, M., Orłowski, G., Panek, M., Skórka, P., Sparks, T.H., Tworek, S., Wuczyński, A. \& Żmihorski, M. (2011) Conservation of Farmland Birds Faces Different Challenges in Western and CentralEastern Europe. Acta Ornithologica, 46, 1-12.

Tscharntke, T., Tylianakis, J.M., Rand, T.A., Didham, R.K., Fahrig, L., Batáry, P., Bengtsson, J., Clough, Y., Crist, T.O., Dormann, C.F., Ewers, R.M., Fründ, J., Holt, R.D., Holzschuh, A., Klein, A.M., Kleijn, D., Kremen, C., Landis, D.A., Laurance, W., 
Lindenmayer, D., Scherber, C., Sodhi, N.S., Steffan-Dewenter, I., Thies, C., van der Putten, W.H. \& Westphal, C. (2012) Landscape moderation of biodiversity patterns and processes - eight hypotheses. Biological Reviews, 87, 661-685.

Uthes, S. \& Matzdorf, B. (2013) Studies on Agri-environmental Measures: A Survey of the Literature. Environmental Management, 51, 251-266.

van Swaay, C., Warren, M. \& Loïs, G. (2006) Biotope Use and Trends of European Butterflies. Journal of Insect Conservation, 10, 189-209.

Verhulst, J., Kleijn, D. \& Berendse, F. (2006) Direct and indirect effects of the most widely implemented Dutch agri-environment schemes on breeding waders. Journal of Applied Ecology, 44, 70-80.

Weiss N., Zucchi H., Hochkirch A. (2013) The effects of grassland management and aspect on Orthoptera diversity and abundance: site conditions are as important as management. Biodiversity and Conservation 22, 2167-2178.

Wilson, J.B., Peet, R.K., Dengler, J. \& Pärtel, M. (2012) Plant species richness: the world records. Journal of Vegetation Science, 23, 796-802. 
Chapter 2 - Plants and Orthoptera react to different local and landscape effects

\section{Supplementary material}

Table S1 List of plant species found in the study that are characteristic for the phytosociological classes Festuco-Brometea (FB) and Molinio-Arrhenatheretea (MA) in Romania (following Sanda et al. 2008).

\begin{tabular}{|c|c|c|}
\hline Species & FB & MA \\
\hline Agrostis capillaris & & $\mathrm{x}$ \\
\hline Ajuga genevensis & $\mathrm{x}$ & \\
\hline Allium oleraceum & $\mathrm{x}$ & \\
\hline Alopecurus pratensis & & $\mathrm{x}$ \\
\hline Anthoxanthum odoratum & & $\mathrm{x}$ \\
\hline Anthyllis vulneraria & $\mathrm{x}$ & \\
\hline Arabis hirsuta & $\mathrm{x}$ & \\
\hline Asperula cynanchica & $\mathrm{x}$ & \\
\hline Centaurea jacea & & $\mathrm{x}$ \\
\hline Centaurea nigrescens & & $\mathrm{x}$ \\
\hline Cerastium holosteoides & & $\mathrm{x}$ \\
\hline Dianthus carthusianorum & $\mathrm{x}$ & \\
\hline Echium vulgare & $\mathrm{x}$ & \\
\hline Eryngium campestre & $\mathrm{x}$ & \\
\hline Euphorbia cyparissias & $\mathrm{x}$ & \\
\hline Euphrasia stricta & $\mathrm{x}$ & \\
\hline Festuca pratensis & & $\mathrm{x}$ \\
\hline Festuca rubra & & $\mathrm{x}$ \\
\hline Filipendula vulgaris & $\mathrm{x}$ & \\
\hline Galium verum & $\mathrm{x}$ & \\
\hline Koeleria macrantha & $\mathrm{x}$ & \\
\hline Lathyrus pratensis & & $\mathrm{x}$ \\
\hline Lotus corniculatus & & $\mathrm{x}$ \\
\hline Lysimachia nummularia & & $\mathrm{x}$ \\
\hline Medicago falcata & $\mathrm{x}$ & \\
\hline Ononis arvensis & & $\mathrm{x}$ \\
\hline Ononis spinosa & $\mathrm{x}$ & \\
\hline Phleum phleoides & $\mathrm{x}$ & \\
\hline Pimpinella saxifraga & $\mathrm{x}$ & \\
\hline Plantago lanceolata & & $\mathrm{x}$ \\
\hline Poa angustifolia & $\mathrm{x}$ & \\
\hline Poa pratensis & & $\mathrm{x}$ \\
\hline Polygala comosa & & $\mathrm{x}$ \\
\hline Potentilla argentea & $\mathrm{x}$ & \\
\hline Potentilla recta & $\mathrm{x}$ & \\
\hline Prunella laciniata & $\mathrm{x}$ & \\
\hline
\end{tabular}

\begin{tabular}{lcc}
\hline Species (cont) & FB & MA \\
\hline Prunella vulgaris & & $\mathrm{x}$ \\
Ranunculus acris & & $\mathrm{x}$ \\
Rhinanthus minor & & $\mathrm{x}$ \\
Rumex acetosa & $\mathrm{x}$ & \\
Salvia nemorosa & $\mathrm{x}$ & \\
Salvia pratensis & $\mathrm{x}$ & \\
Salvia verticillata & $\mathrm{x}$ & \\
Sanguisorba minor & $\mathrm{x}$ & \\
Senecio erucifolius & $\mathrm{x}$ & \\
Senecio jacobaea & $\mathrm{x}$ & \\
Stachys germanica & & $\mathrm{x}$ \\
Stellaria graminea & $\mathrm{x}$ & \\
Thesium linophyllon & $\mathrm{x}$ & \\
Trifolium campestre & & $\mathrm{x}$ \\
Trifolium dubium & $\mathrm{x}$ & \\
Trifolium montanum & & $\mathrm{x}$ \\
Trifolium pratense & & $\mathrm{x}$ \\
Trifolium repens & & \\
Verbascum lychnitis & & \\
Vicia cracca &
\end{tabular}

(1)


Table S2 Classification of Orthoptera species found in the investigation (for explanations of ecological groups see Methods section).

\begin{tabular}{|c|c|c|c|}
\hline Species & $\%$ sites present & Habitat preference & Mobility \\
\hline Bicolorana bicolor & 22.7 & mesic & sedentary \\
\hline Calliptamus italicus & 4.0 & non-mesic & mobile \\
\hline Chorthippus biguttulus & 18.7 & mesic & mobile \\
\hline Chorthippus brunneus & 9.3 & mesic & mobile \\
\hline Chorthippus dorsatus & 61.3 & mesic & mobile \\
\hline Chorthippus mollis & 2.7 & mesic & mobile \\
\hline Chorthippus oschei & 6.7 & mesic & mobile \\
\hline Conocephalus fuscus & 1.3 & non-mesic & mobile \\
\hline Decticus verrucivorus & 4.0 & mesic & mobile \\
\hline Euchorthippus declivus & 54.7 & non-mesic & sedentary \\
\hline Euthystira brachyptera & 14.7 & mesic & sedentary \\
\hline Leptophyes albovittata & 9.3 & mesic & sedentary \\
\hline Myrmeleotettix maculatus & 2.7 & non-mesic & mobile \\
\hline Oecanthus pellucens & 42.7 & non-mesic & mobile \\
\hline Omocestus haemorrhoidalis & 13.3 & mesic & mobile \\
\hline Omocestus rufipes & 14.7 & mesic & mobile \\
\hline Pezotettix giornae & 1.3 & non-mesic & sedentary \\
\hline Phaneroptera falcata & 20.0 & non-mesic & mobile \\
\hline Poecilimon fussii & 6.7 & mesic & sedentary \\
\hline Pseudochorthippus parallelus & 50.7 & mesic & sedentary \\
\hline Pseudopodisma fieberi & 2.7 & mesic & sedentary \\
\hline Roeseliana roeselii & 2.7 & mesic & sedentary \\
\hline Ruspolia nitidula & 8.0 & non-mesic & mobile \\
\hline Stenobothrus crassipes & 24.0 & mesic & sedentary \\
\hline Stenobothrus lineatus & 21.3 & mesic & mobile \\
\hline Stenobothrus nigromaculatus & 10.7 & non-mesic & sedentary \\
\hline Stenobothrus stigmaticus & 17.3 & mesic & sedentary \\
\hline Tetrix undulata & 1.3 & mesic & mobile \\
\hline
\end{tabular}




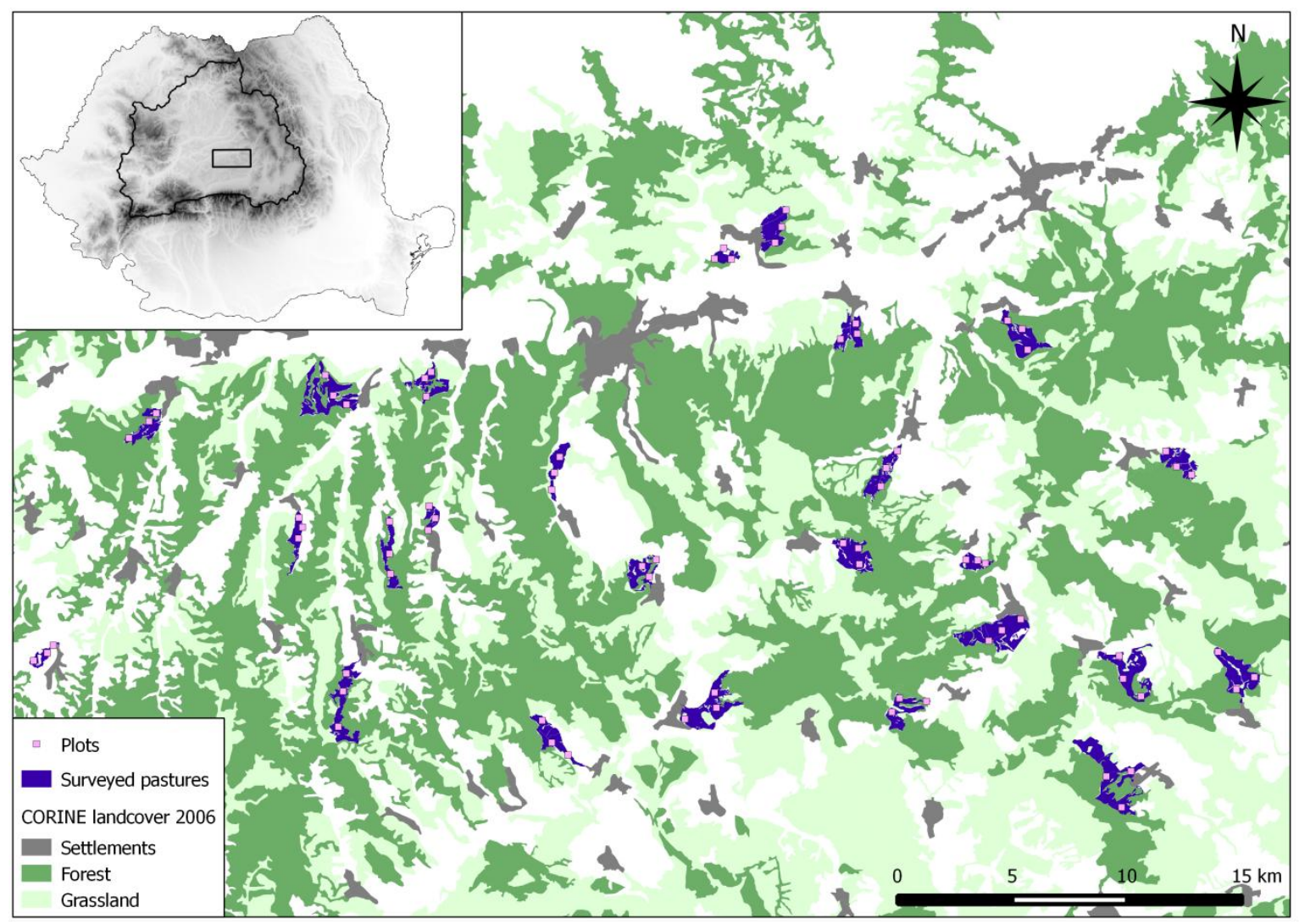

Figure S1 Location of the 75 plots (pink) and 25 pastures surveyed in this study (blue) in the region of Southern Transylvania (Lat. $46.1434^{\circ}$ Long. $24.7882^{\circ}$, see also the accompanying Google Earth .kmz file in the electronic material). The inset is a digital elevation map of Romania showing the region of Transylvania (thick black line) within the arch of the Carpathian Mountains, and the study area (black box). Land-cover data: CORINE 2006, DEM: Diva-GIS free spatial data. 
Chapter 2 - Plants and Orthoptera react to different local and landscape effects

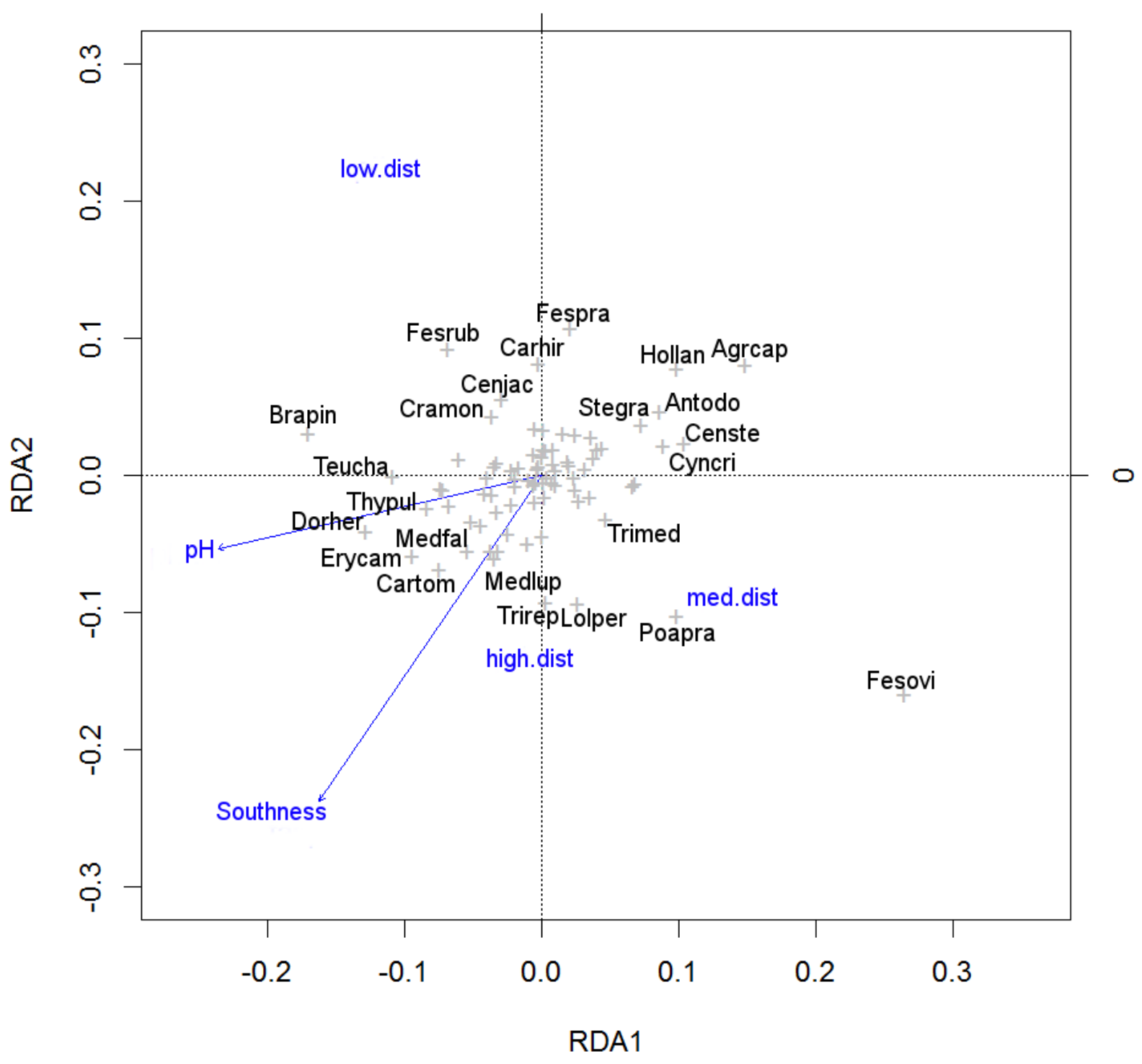

Figure S2 RDA of plant species composition with the constrained variables (blue) that showed a significant effect, including the conditional variable pasture location (see Table 3). Only the names of species showing the highest variation are shown. Abbreviations: Agrcap = Agrostis capillaris, Antodo $=$ Anthoxanthum odoratum, Brapin $=$ Brachypodium pinnatum, Carhi $=$ Carex hirta , Cartom $=$ Carex tomentosa, Cenjac $=$ Centurea jacea, Censte $=$ Centaurea stenolepis, Cramon $=$ Crataegus monogyna, Cyncri $=$ Cynosurus cristatus, Dorher $=$ Dorycnium herbaceum, Erycam $=$ Eryngium campestre, Fesrub $=$ Festuca rubra, Fesovi $=$ Festuca ovina, Fespra $=$ Festuca pratensis, Hollan $=$ Holcus lanatus, Lolper $=$ Lolium perenne, Medfal $=$ Medicago falcata, Medlup $=$ Medicago lupulina , Poapra $=$ Poa pratensis, Stegra $=$ Stellaria graminea, Teucha $=$ Teucrium chamaedrys, Thypul $=$ Thymus pulegioides, Trimed $=$ Trifolium medium, Trirep = Trifolium repens . 
Chapter 2 - Plants and Orthoptera react to different local and landscape effects

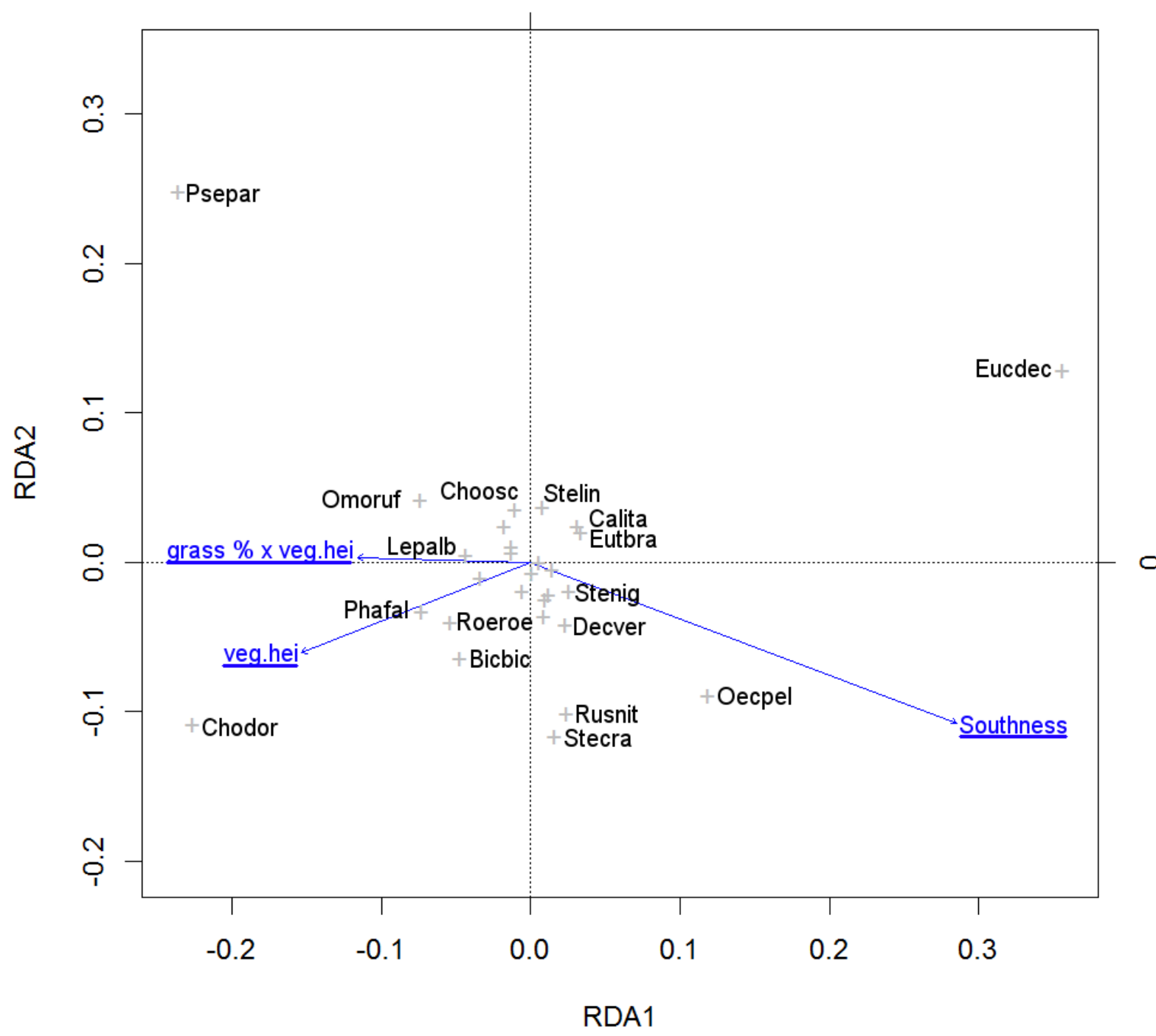

Figure S3 RDA of Orthoptera species composition, showing only the constrained variables (blue) that showed a significant effect (see Table 3). Only the names of species showing the highest variation are shown. Species abbreviations are the first three letters of the genus plus the first three of the species names (for species see Table S1). 


\section{Chapter 3}

\section{Pastoral commons use in Romania and the role of the Common Agricultural Policy}

Laura M. E. Sutcliffe, Inge Paulini, Gwyn Jones, Rainer Marggraf \& Nathaniel Page

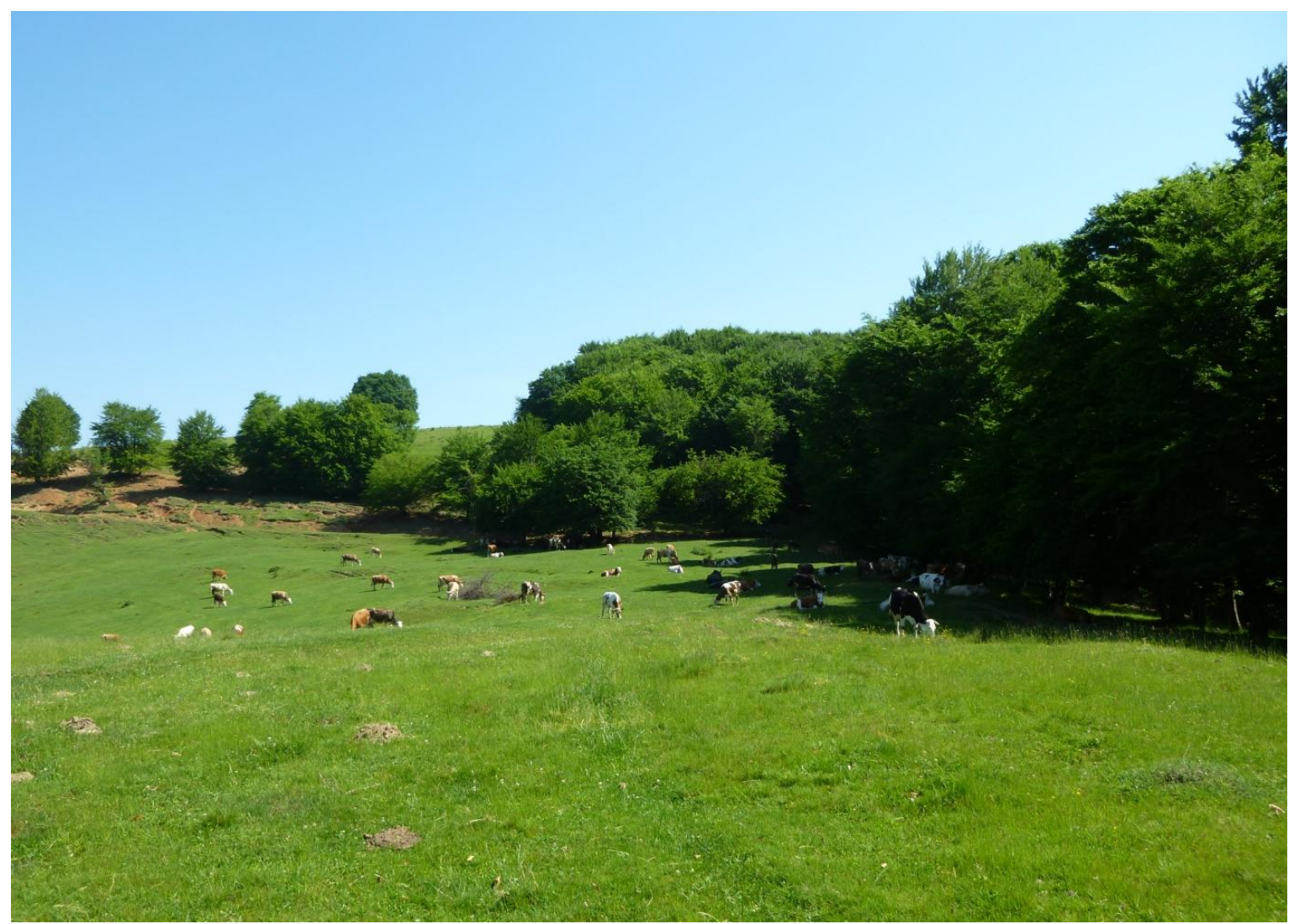

International Journal of the Commons, 7, 58-72 (2013) 


\begin{abstract}
In comparison to many Western European countries, in Romania the use of common pastures remains widespread and is strongly linked to the predominance of subsistence and semisubsistence farming in much of the country. The majority of permanent pasture in the country is under state or community ownership, and these areas are of high natural and cultural, as well as economic importance for Romania. Whilst traditional governance systems of the commons are still partly intact, or at least within living memory here, new institutions are forming in response to substantial changes in agriculture and rural life that have been occurring, particularly since Romania's accession to the EU in 2007. We describe the changing role of common pastures for local communities in the case study region of Târnava Mare in Southern Transylvania, Romania. The number of active users here is decreasing, and those who have more animals are increasingly grazing their animals on long-term leased or private land, thus effectively no longer participating in the commons. This is encouraged by the current system of relatively low prices for agricultural products and EU agricultural support payments, which for smallholders and larger farmers alike are now a major factor in the financial viability of farming in Romania. The future of the commons in the study region will hinge on the success of the communities to self-organise and take advantage of the opportunities presented by the changing rural context of pastoral commons use.
\end{abstract}

Keywords: Common pastures; Farmer associations; Transylvania; Subsistence farming; Collective action; Agricultural policy. 


\section{Introduction}

Common grazing in Romania, as in much of Europe, is a historical tradition (Dorner 1910; De Moor, Shaw-Taylor, \& Warde 2002; Brown 2006a). However, in contrast to much of Western Europe and despite great upheavals in land ownership during the past century, this form of land use still plays an important role in Romania. Here, common grazing land may be owned by public bodies, private organisations or individuals, but is characterised by multiple grazing rights. Although no exact figures on the distribution of common pastures are available, based on the amount of publicly owned agricultural land in the country (1.87 million ha in 2007), a rough approximation suggests that over half of the 3.4 million ha of permanent pasture in Romania can be considered common land (INS 2010) ${ }^{1}$.

Whilst its significance naturally varies across this culturally diverse country, the vast majority of villages still retain at least one pasture which is used in common by the local inhabitants. The use of these common pastures is strongly linked to the persistence of subsistence and semi-subsistence farming, which is still the major type of agriculture in Romania both in terms of surface area and number of farmers involved (MARD 2007). Around 3.5 million agricultural holdings (90\%) farm on less than 5 ha of individually-farmed land (INS 2010). As a result, Romania has the highest number of holdings per capita in the EU, linked to the large rural population in Romania (see Figure 1). For these families, the possibility of keeping livestock and thus survival as smallholders is contingent on their access to common pastures to supplement their own land. Common pastures therefore represent a major economic resource for small-scale farmers, but are also a source of non-economic benefits for the community.

As generally large areas of unimproved, semi-natural grassland, common pastures throughout Europe are often rich in biodiversity (Lederbogen et al. 2004; Brown 2006b). Their legal status provides them with inertia against land-use change (Wilson \& Wilson 1997), as decisions regarding management require the consent of multiple stakeholders. Such continuity in habitat conditions is particularly important for grassland flora, which may continue accumulating species over tens, if not hundreds, of years (Poschlod and Wallis de Vries 2002; Aavik et al. 2009). Their large scale provides not only the opportunity for large and genetically diverse populations, but also the spatial and temporal gradients of disturbance

\footnotetext{
${ }^{1}$ The vast majority of state or community owned agricultural land is permanent pasture (B. Mehedin, pers. comm.), and this figure does not include the area owned by community organisations, therefore is probably an underestimate.
} 
caused by wandering herds create different habitat types for a variety of species. This diversity of species is also linked with a diversity of functions: in addition to the production of livestock fodder, these extensive permanent pastures can also be a resource for harvesting other important products (such as medicinal plants) as well as having significant carbon sequestration potential (e.g. Smith et al. 2010). Common pastures also provide many less tangible services. Having often been in existence for centuries, their large, unfenced expanses are a typical element of the rural countryside of many areas of Europe, with a strong significance for regional cultural heritage (Rodgers et al. 2011, p14) and tourism (Brown 2006b; Roeder et al. 2010).

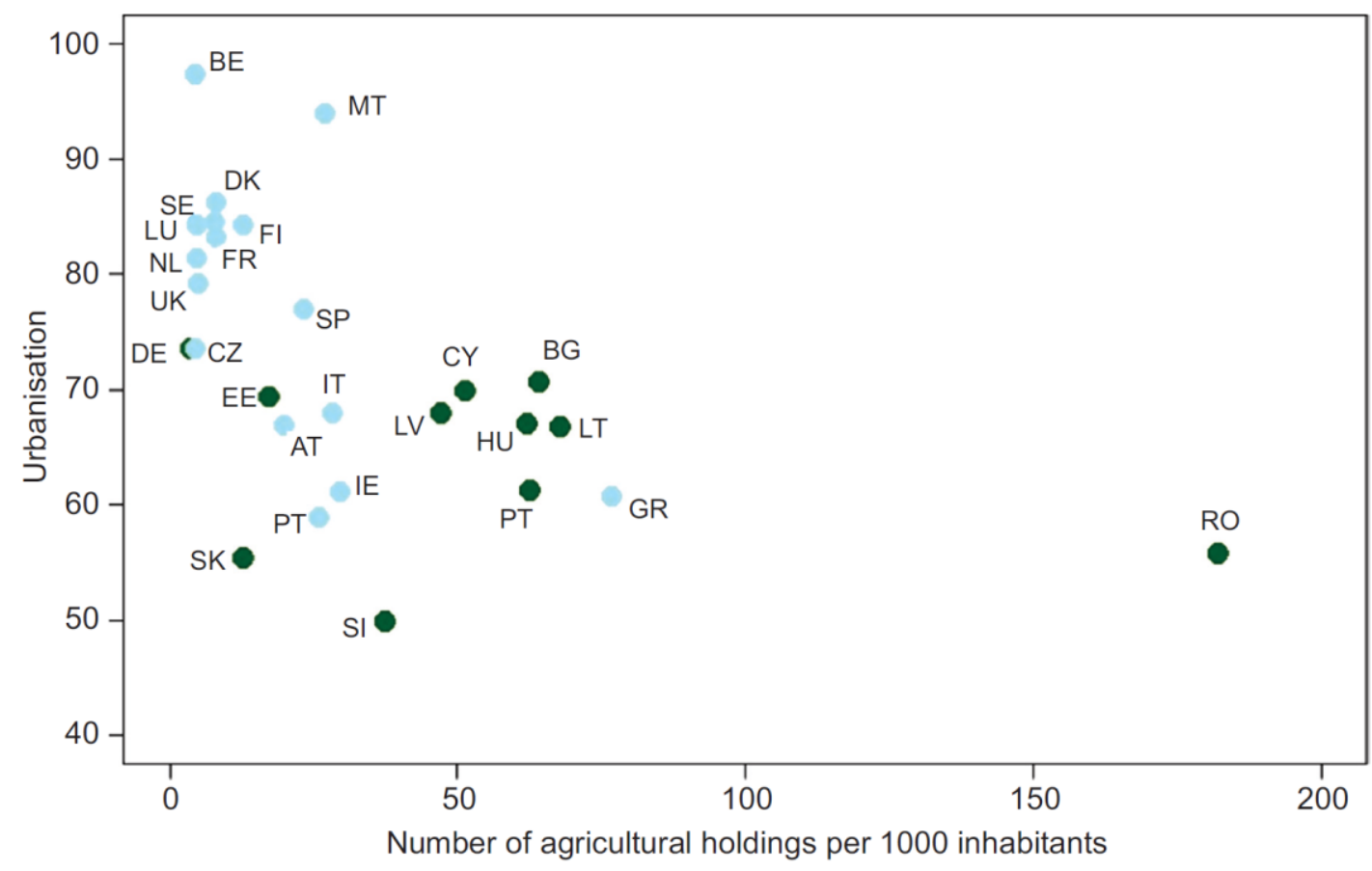

Figure 1 Number of agricultural holdings per thousand inhabitants compared to percentage urban population for each country in the EU27, in 2007. Blue circles = Western Europe, green circles Central and Eastern Europe. Points are labelled with country abbreviations (RO=Romania). (Source: Eurostat 2011 for agricultural holdings, FAOSTAT 2012 for urban population).

Despite their wealth of commons, Eastern Europe is largely understudied in this aspect (Bravo $\&$ De Moor 2008), and thus provides an interesting new context in which to test the relevance of the findings and recommendations in the commons literature (Sikor 2004). Unlike many other European countries, Romania still retains widespread living memory of historic, stable commons institutions (as described by e.g. Dorner 1910). However, repeated upheavals in agricultural land rights in the last century have placed strain on traditional governance 
systems of common pastures. Forced collectivisation of land and animals under the communist regime undermined the use of the commons and their autonomous local governance. Following the revolution in 1989 and the slow - and still incomplete - process of land and property restitution, these institutions appear to have regained strength, but rarely to the former levels of organisation. Most recently the accession of Romania to the European Union brought liberalisation of markets and the introduction of Common Agricultural Policy (CAP) instruments, again rapidly changing the context of common land use. In many cases the formation of new commons institutions is occurring on top of fragments of older ones, but with the added challenges of widespread post-socialist mistrust in collective action and an uncertain future for agriculture in the country.

This paper summarises the current situation of common pasture use in the case study area of Târnava Mare in Southern Transylvania, an 85,000 ha Natura 2000 protected area characterised by lowland, low-intensity and largely grassland-based farming (Figure 2). We first outline the types of commons considered in the context of Romania as a whole. The development of common pasture use over the past several centuries is then summarised, followed by a discussion of its changing role in the community today and what internal and external factors may be driving this. Particularly important in this respect are the effects of the EU CAP, as well as of the appearance of new farmer associations, whose significance for the commons will be described. Based on this, we consider the implications for the sustainability of the commons in the study area, and their future prospects.

\section{Methods}

Data were gathered during a pilot study consisting of ten qualitative semi-structured interviews with commons users from seven villages in the study area in summer 2011. Both smallholders with few animals and larger-scale, more specialised farmers were interviewed. Questions focussed mainly on commons use by cattle, and concerned the major themes of historical and present pasture use patterns, relevant organisational structures, cooperation among users and the influence of subsidies on commons use. Statements on these themes were then extracted from the interview notes and compared, and complemented by information from the literature and observational data from ecological fieldwork on the common pastures in question in 2011. 


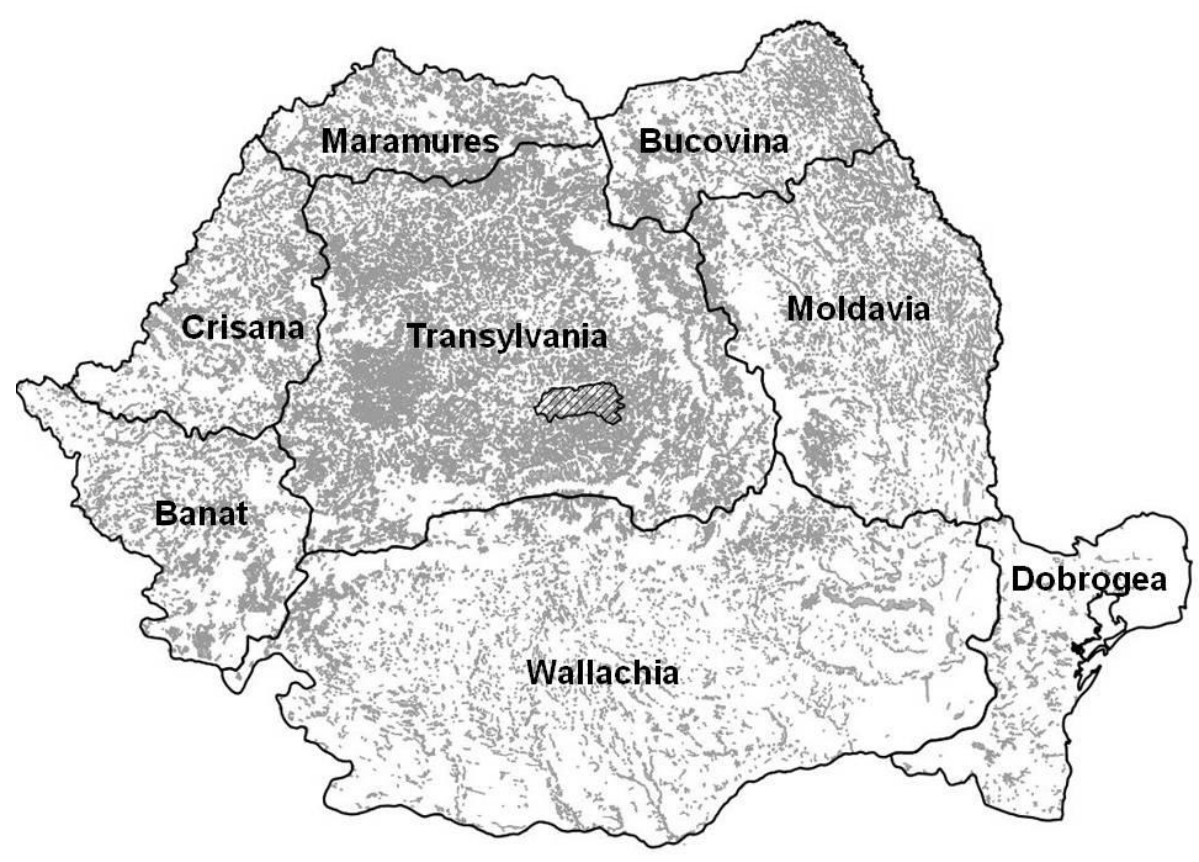

Figure 2 Map of Romania showing the location of the Târnava Mare study region (hatched). Grey shading shows distribution of pasture taken from CORINE Landcover Data 2006.

\section{Commons in the study region and the Romanian context}

Today, large areas of both forest and pasture commons in Romania exist, for which there are three main administrative models (see Table 1 for an overview). The composesorat is a historic community organisation typical in Transylvania and northern Romania that owns and administers pasture and forest land. Membership is usually strongly restricted, often passed down through generations. The second type, obşte, is a similar community organization found in the mountainous regions of Wallachia and Moldavia, with a wide variation in membership rights (Mantescu 2009). In the majority of the country, however, the common pasture (often called izlaz) is publicly owned with administration carried out through the Town Hall. This rents out parcels of the pasture to individuals based on their needs, or makes the area available for common grazing and has traditionally applied a tax per animal for usage. The former is generally the case for sheep pastures, where shepherds rent land on which to graze and milk a mixture of their own and the villagers' sheep. The latter is generally the case for cow pastures. In most cases, any resident of the village has the right to use the common pasture to graze their animals. 
Table 1 Overview of the three main types of common pasture use in Romania (based on Mantescu 2009)

\begin{tabular}{lllll}
\hline Commons type & Property rights & \multicolumn{1}{c}{ Use rights } & Administration & Main distribution \\
\hline composesorat & $\begin{array}{l}\text { Private property of } \\
\text { the local community }\end{array}$ & $\begin{array}{l}\text { Can be restricted to } \\
\text { members (although not } \\
\text { always); membership } \\
\text { usually inherited }\end{array}$ & Elected members & $\begin{array}{l}\text { (Hungarian } \\
\text { speaking) } \\
\text { Transylvania and } \\
\text { N. Romania }\end{array}$ \\
\hline \multirow{2}{*}{ obște } & $\begin{array}{l}\text { Pestricted to members; } \\
\text { the local community }\end{array}$ & $\begin{array}{l}\text { membership sometimes } \\
\text { inherited, sometimes } \\
\text { through residence }\end{array}$ & Elected members & $\begin{array}{l}\text { Regions of } \\
\text { Wallachia and } \\
\text { Moldavia }\end{array}$ \\
\hline izlaz & $\begin{array}{l}\text { Public property of } \\
\text { the local community }\end{array}$ & $\begin{array}{l}\text { Any inhabitant of the } \\
\text { municipality }\end{array}$ & $\begin{array}{l}\text { Mayor and elected } \\
\text { pastoral committee }\end{array}$ & $\begin{array}{l}\text { Throughout } \\
\text { Romania }\end{array}$ \\
\hline
\end{tabular}

The izlaz form of public ownership of land with management by the Town Hall is the typical system of grazing commons administration in the study region of the Târnava Mare region of lowland Southern Transylvania (see Figure 2). This area has a long history of low intensity farming and high proportion of pastoralism linked with semi-subsistence farming (Page et al. 2012). Common land has been a feature of the farming system in the area since at least the $16^{\text {th }}$ century (Dorner 1910). Today, almost all permanent pasture is publicly owned in this region, and a typical municipality has around 3000 ha of communal pastures (roughly a third of the administrative area). The pasture area may be physically contiguous over hundreds of hectares, but is often divided into multiple units depending on the users' needs and the physical geography.

\section{Historical development}

The interviewees reported that historically, the use of the common pastures in Târnava Mare was restricted in practice and/or by local regulations by the number of animals a household could overwinter. Whilst the main use today is for cattle and sheep grazing (both for dairy production), in the past the pastures were also important for buffalo (from the $18^{\text {th }}$ to the end of the $20^{\text {th }}$ century) and pigs (at least since the $16^{\text {th }}$ century, until the $20^{\text {th }}$ century). The latter could be a reason for the high frequency of wood pastures in the area, whose scattered trees (mostly oaks) were a source of acorns and other forage for pigs (Hartel \& Moga 2010).

The right of local inhabitants to use the pasture was coupled with a tax per animal payable to the local council and a fee to the herdsman, at least since the end of the $19^{\text {th }}$ century if not much earlier. In addition, each individual had to contribute a certain number of days work per year per animal grazed to maintain the pasture (scrub and weed clearance, repairing of water 
troughs etc.), overseen by a pastoral committee from the Town Hall. Issues regarding the pasture were discussed and decided upon in an annual public meeting in spring presided over by the mayor (or vice mayor) and the pastoral committee in all study villages. This included electing a cowherd, who during the summer months would take the animals every morning to the allocated pasture and return them to their owners in the evening. The meeting was attended by all stakeholders, who were almost exclusively subsistence or semi-subsistence farmers, usually owning 1-5 cows and 5-20 sheep in addition to other livestock. For such users, the quality of the pasture was paramount to their livelihoods, and the time and labour saving benefits of communal grazing vastly overcame any costs involved in participating in the commons (Huband 2007).

This changed during the communist period (1947-1989), when most land in Romania was collectivised and the majority of pastures - as well as the animals that grazed them - were absorbed into state or collective farms. However, individuals continued to keep a few animals during this period, and some of the common pastures remained in use as such. Administration of the pastures continued from the Town Hall with the participation of the local livestock owners, however, this was now strongly driven by the directors of the state and collective farms. The carrying out of pasture maintenance activities by users was strictly enforced by the Town Hall.

Following restitution of land and animals in the 1990s, pasture maintenance was increasingly neglected (as confirmed by all interviewees), as the state ceased to play such a dominant role in this respect and the users failed to coordinate themselves to continue these activities without state enforcement. Falling prices for agricultural products in recent years, as well as rising costs of living and emigration of young people due to the lack of rural job opportunities has led to a reduction in number of households keeping animals. These trends have particularly affected subsistence and semi-subsistence farmers, which form the majority of the commons users, making it an ageing group (see Figure 3) with few future prospects.

In contrast, a minority of livestock owners have expanded their herds (i.e. over 10 cows) and professionalised their farming operations. These, however, operate separately from the village herd, using either private pasture or rented parcels of the communal pasture. In some places this is an official rule, in others just the norm. In having more at stake with their livestock, these owners tend to remove themselves willingly from the commons system because it is no longer practical for them (they may have different milking times, or find it more convenient to keep their cattle out of the village, for example). 


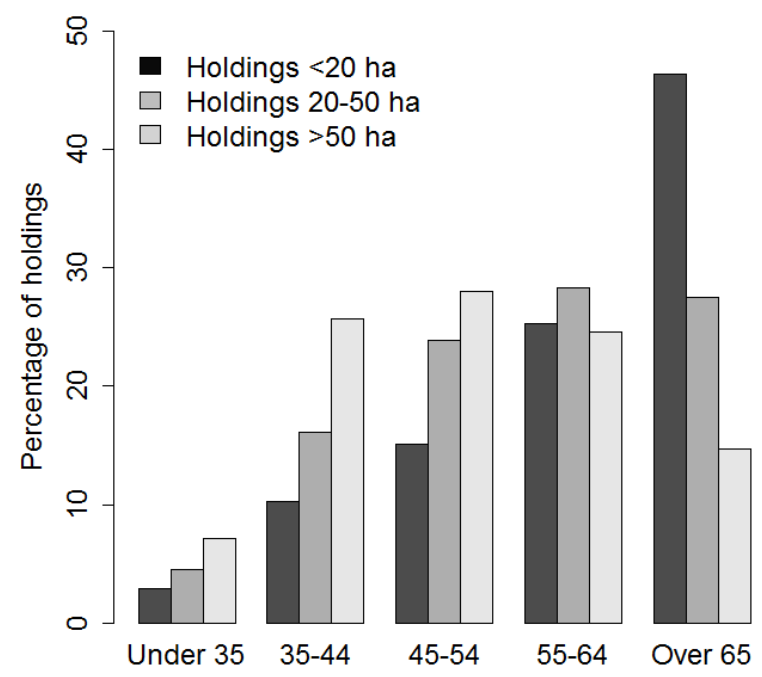

Figure 3 Distribution of small (under 20 ha, average size for this size class is 4.5 ha), medium (20-50 ha, average $30 \mathrm{ha}$ ), and large (over 50 ha - average 300 ha) farm holdings in Romania per age-group of farm manager. Source: Eurostat 2009.

In terms of pasture governance, the precipitous decline in the number of families keeping cows and thus reduction in the circle of active users has led to a loss of saliency (sensu Ostrom 2001) of the common pastures for the local community. This may be one of the reasons for the lack of engagement in communal pasture maintenance. These two factors combined, i.e. the reduction in management such as scrub clearance and the reduced grazing pressure, are threatening the quality of the pasture both in terms of productivity (and thus profit) and nature value.

\section{Effects of changes in agricultural policy}

Romania's accession to the EU in 2007 has had a range of impacts on agriculture in general in the country, which have in turn modified the context of commons use. Interacting with the falling prices and rural exodus mentioned in the previous section has been the introduction of agricultural subsidy payments in line with the EU Common Agricultural Policy (CAP). In the study area, initially many Town Halls applied for the subsidy payments. In return they often released the users from paying taxes and pasture maintenance responsibilities, which had in recent years rarely been properly enforced. However, although the users were freed from some financial costs, the subsidy money was not effectively benefiting either the users or the pasture quality. In recognition of this problem, the Ministry of Agriculture tightened regulations to prevent Town Halls from applying, with the result that the renting of communal pasture (by individuals or associations) increased. Many farmer or grazing associations were 
thus formed in order to take advantage of the subsidy payments. In one of the study villages, the association used the subsidy money to invest in improving the pasture quality or facilities, such as agricultural machinery, for the local community. Such examples of collective action to achieve greater collective benefits from the money are, however, few, and several interviewees said the associations simply divided the amount among the active members who used it to supplement their income.

An additional effect of CAP payments was the lengthening of contracts for the leasing of communal land. In addition to the single area payment (CAP Pillar I, Direct Payments), agrienvironment schemes (CAP Pillar II, Rural Development) are also available for grasslands in many areas of the country. These require the applicant to have rights to the land for a period of at least 5 years, and thus to allow access to this source of funding Town Halls generally grant contracts for 5 , but also even 10 or 25 years. This extended period is intended to provide planning security for land-owners, especially as the intended ecological benefits of agrienvironment schemes often take many years to accrue. In the context of the common pastures in the study areas, however, this development has had the side effect of weakening its communal function. In the absence of effective collective action to take control of the communal pasture, wealthier individuals have the opportunity to rent areas for extended periods of time, promoting a single user 'private' model of land use, which has implications both for both social and ecological functions of the common pasture. Concerning the former, some interviewees noted that land had been rented to residents of other villages, or to individuals without animals, despite the fact that theoretically this was not permitted according to the rules of the Town Hall. The primary interest of the tenant was the subsidies, who in some cases then sublet the land to locals who had not been able to obtain land for their animals directly from the Town Hall. In addition to the social justice issues with this situation, increased opportunity for individuals to make management decisions increases the likelihood of land-use change, which may in the case of species-rich permanent pastures be ecologically harmful (Wilson \& Wilson 1997).

\section{New associations and their effect on commons governance}

Although there have been similar organisations in the past, local farmer associations have started to appear on a larger scale in Romania in recent years. Officially encouraged by the Romanian government, they have, however, been given little formal support as to how to organise and regulate themselves, and as such a multitude of forms exist with varying success. 
At one end of the scale there are well-functioning farmer associations consisting of the majority of farmers in the village, and an organisational structure with different administrative positions. The other, more frequently encountered, situation is that the association is a shell, only existing formally in order for its members to be able to receive subsidy payments but with no willing participation of or interest from the members. In one village without an association, one interviewee rented part of the common pasture as an individual and let village animals graze in an informal agreement, by-passing the formal rules of commons use. Lack of unity and organisation among the users means that decisions about the common pasture mostly continue to be driven in a top-down manner by the Town Hall. This has no strong vested interest in the quality of the pasture or the livelihoods of its users, unlike the farmer associations. In turn, this inability by users to influence the running and the regulation of the commons is a major barrier to trust in and commitment to an institution (e.g. Ostrom 1990).

Concerning the interaction between associations and subsidy payments, there is a recognised lack of administrative capacity for managing CAP instruments in Romania and a generally poor level of dissemination of information regarding agricultural policy (Wegener et al. 2011). Farmers largely rely on uncoordinated trickle-down of policy and administrative information through word of mouth or television (Huband 2007, Paulini et al. 2011), leading to information asymmetries and a lack of transparency. This is worsened by a high potential for conflict caused by the substantial sums of money in play: in 2012, basic CAP payments per hectare of grassland (based on direct payments and the most popular agri-environment schemes) were around $270 €$ - equivalent to an average Romanian monthly wage. Typical post-socialist mistrust in institutions and authorities (e.g. Theesfeld 2004) is very present in the region due to frequent corruption experienced by people here, all interviewees noted that it is a central issue in the running of the grazing associations. Low levels of social capital present in the community ( $\mathrm{T}$. Hartel unpublished data) also decrease the willingness to cooperate.

\section{Implications for the sustainability of commons use and future prospects}

The application of the Common Agricultural Policy, in conjunction with market liberalization and significant socio-economic changes, has made Romanian farmers dependent on CAP payments. In the current economic climate, these subsidies play an important role in the viability of farming from the smallest to the largest scale. As an integral part of Romanian agriculture, common pastures must therefore now also be managed to efficiently exploit this 
source of financial support. Without it, common grazing would surely continue, at least into the near future, but mainly as the historical hangover of tradition and poverty-induced dependence on subsistence agriculture.

In the absence of effective collective action, the intended positive influence of CAP subsidies appears to be only partially successful for the social and ecological functions of the common pastures in the study area. Whilst the management stipulations for payments have stimulated an improvement in e.g. scrub clearance in recent years, all interviewees confirmed that this activity is now dependent on the continuation of the subsidy payments and not sustainable should these cease. In this way, the direct link between farmers and the environment is being eroded by the current system. Whereas previously ecological sustainability was key to producing the fodder that farmers depended on, in many areas today the primary product of the pasture is the cash that they receive for just ensuring the pasture meets the minimum standards prescribed by the payments agency. This provides incentives for people outside the community, and even those with no livestock or link to the area, to rent common land but not necessarily to use it.

With the drop in interest from livestock owners and the greater convenience of the private land use model for land administration, many interviewed farmers predicted the gradual decline in use of the common pasture in the next decade, to be replaced by individual renting of parcels of public land. In turn, the current dysfunctionality of the farmer associations is contributing to the speed of the loss in commons users, as they are failing to use the agricultural support payments to the benefit of the community. Whilst any reduction in the number of livestock is easily reversible, the loss of livestock owners (and thereby the use of the commons) is not: once the knowledge and tradition of livestock-keeping is lost in a family, it is unlikely to be regained.

As mentioned above, the current system is facilitating an increasing 'quasi-privatisation' and division of the common pastures, which appears to be weakening the tradition of collective management of large areas of land. A greater recognition of the importance of landscape scale approach in international agricultural policy has been repeatedly called for in the ecological literature (e.g. Gabriel et al. 2010; Reeson et al. 2011), due to the ecological linkages affecting species stretching over hundreds of hectares, rather than the tens of hectares addressed by most current measures. This concept is perfectly addressed by common pastures, which provide large expanses of contiguous grassland supporting high species richness and ecosystem services with relatively low transaction costs. 
Despite this recognition, and the stated objective of the CAP to encourage environmentally friendly farming (EC 2011a) there is no special recognition of common pastures or collective action to manage agricultural landscapes under the current CAP. This could still be addressed in the post 2013 agricultural policy. For example, a new cooperation measure to support collective action has been formulated under the legislative proposals for the post-2013 CAP (EC 2011b), which could be used to increase central support, advisory services and targeted aid for local farmer associations. In addition, although much of the content of the new CAP for the next programming period is already known at the EU level, it is likely that there will be more flexibility than in previous years for individual Member States to interpret the regulations. Romania in particular will have a much increased Direct Payments budget in the new 'green' Pillar I in comparison to the previous CAP period (Bureau \& Witzke 2010). This, along with the cooperation measure could be a powerful tool to promote landscape scale conservation if eligibility restrictions for grazed land (which currently exclude much land of high nature value owing e.g. to the presence of isolated trees) are relaxed.

Although a change in national and international policy may be one way to better support the use of common pastures, there is much that local collective action could achieve to improve the functioning of farmer associations. As Romania makes its transition from an agricultural system characterised by subsistence farming to more commercial farming, the continued use of the common pastures seems to rest with the small to medium-sized farmers. This period of restructuring of commons governance can be seen as an opportunity to change the system to make it a more attractive option for these farmers to use. The newly formed, or reconstituted, farmer associations could help the transition from subsistence farming and better exploit the full potential of CAP payments and international markets by taking over the management of the commons. Transaction costs for small- and medium-sized holdings can be greatly decreased, for example by associations making a central application for agricultural payments, or by providing a resource for equipment, advice and labour - as has happened in a very few positive cases. By acting as a voice for the concerns of small farmers, problems related to the lack of representation of their interests at higher administrative levels (Wegener et al. 2011) can be addressed. Issues with transparency, accountability, trust and member involvement could be initially improved by the formation of umbrella organisations to provide support, structure and guidance for local associations. Nevertheless, associations will remain highly dependent on the integrity and level of engagement of individuals such as the head of the association. 


\section{Conclusions}

The large areas of common land still existing in Romania support millions of smallholders as well as important ecosystems, and form part of the cultural heritage of many regions of the country. Rapid recent changes including the introduction of agricultural subsidy payments and decline in subsistence farming mean, however, that the commons institutions are currently facing unprecedented challenges. In the study area, the disappearance of small farmers means the circle of active users is shrinking, resulting in a loss of saliency of the common pastures for the local community as a whole. In addition, the shift from primarily resource-based to subsidy-based usage is changing the role of the common pastures, replacing the direct link between farmers and the environment with an indirect one, thus reducing the importance of ecological sustainability (Fischer, Hartel, \& Kuemmerle 2012). A move towards effective division and individual use of the commons is also being seen in the region as a result of the subsidy system, and with the continued transition from subsistence to commercial farming this quasi-privatisation trend is likely to continue.

Nevertheless, many of the challenges described here can also be seen as an opportunity to form better systems of management. If issues with transparency and accountability can be addressed, farmer associations may be able to facilitate the use of the commons - and the subsidies they provide - for smaller-scale farmers, helping both them and the commons system to survive. Advisory services for such associations could have an important role to play to help inexperienced associations restructure as sustainable institutions. This case study is not unique, and at both the national and the European level the role of commons and associations of land managers in providing landscape-scale High Nature Value habitats could be better acknowledged in agricultural policy.

Based on a small case study, the discussion above is naturally limited in its scope to draw conclusions for Romania as whole, especially in terms of the picture for other forms of commons management such as the composesorat and the obşte. Further research comparing the situation and outlook for the management of the common pastures in other regions of the country, especially regarding the effects of CAP subsidies, would help to form a more complete picture of the range of impacts that the recent changes have had. This could provide evidence to shape future policies promoting collective action for both production and conservation in agricultural landscapes. 


\section{Acknowledgments}

The authors would like to thank Tibor Hartel for useful discussion, as well as all the staff of Fundația ADEPT for assisting the data collection. We are also very grateful for the helpful comments of the editors and three anonymous reviewers, which improved this manuscript considerably. LS was supported by a grant from the Ministry of Education and Culture in Lower Saxony.

\section{References}

Aavik, T., Jõgar, Ü., Liira, J., Tulva, I. \& Zobel, M. (2009) Plant diversity in a calcareous wooded meadow - The significance of management continuity. Journal of Vegetation Science, 19, 475-484.

Bravo, G. \& De Moor, T. (2008) The commons in Europe : from past to future. International Journal of the Commons, 2, 155-161.

Brown, K.M. (2006a) New challenges for old commons: The role of historical common land in contemporary rural spaces. Scottish Geographical Journal, 122, 109-129.

Brown, K.M. (2006b) Common land in Western Europe: anachronism or opportunity for sustainable rural development? IASCP Europe Regional Meeting: Building the European Commons: from Open Fields to Open Source Brescia - Italy.

De Moor, M., Shaw-Taylor, L. \& Warde, P. (2002) Comparing the historical commons of north west Europe. The management of common land in north west Europe, c. 15001850 (eds M. De Moor, L. Shaw-Taylor \& P. Warde), pp. 15-31. Brepols, Turnhout.

Dorner, B. (1910) Az Erdélyi Szászok Mezögazdasága [The Agriculture of the Transylvanian Saxons]. Györ, Hungary.

EC. (2011a) Agricultural Policy Perspectives Briefs: Brief No 1 Rev January 2011. European Commission, Brussels.

EC. (2011b) Proposal for a Regulation Of The European Parliament And Of The Council on Support for Rural Development by the European Agricultural Fund for Rural Development (EAFRD). COM(2011) 627 Final/2, European Commission, Brussels.

Bureau, J.-C. \& Witzke, H.-P. (2010). The Single Payment Scheme after 2013: New Approach, New Targets. Report prepared for the European Parliament, Brussels.

Eurostat. (2011) Eurostat Yearbook 2011. Brussels (Belgium).

FAOSTAT. (2012) Database of the Food and Agriculture Organization of the United Nations, http://faostat.fao.org [Accessed 20.08.2012] 
Fischer, J., Hartel, T. \& Kuemmerle, T. (2012) Conservation policy in traditional farming landscapes. Conservation Letters, 5, 167-175.

Gabriel, D., Sait, S.M., Hodgson, J.A., Schmutz, U., Kunin, W.E. \& Benton, T.G. (2010) Scale matters: the impact of organic farming on biodiversity at different spatial scales. Ecology Letters, 13, 858-869.

Hartel, T. \& Moga, C. (2010) Manual de Bună Practică În Managementul Habitatelor de Pajişte Cu Arbori Seculari (Good-Practice Guidebook for the Management of WoodPasture Habitats with Veteran Trees). Mihai Eminescu Trust, Sighişoara, Romania.

Huband, S. (2007) The Role of Romanian Pastoralists in Conserving Agricultural Biodiversity. Doctoral dissertation, University of Edinburgh.

INS. (2010) Anuarul Statistic Al României 2010 [The Statistical Yearbook of Romania]. Institutul National de Statistica, Bucharest.

Lederbogen, D., Rosenthal, G., Scholle, G., Trautner, D., Zimmermann, J. \& Kaule, G. (2004) Allmendweiden in Südbayern: Naturschutz Durch Landwirtschaftliche Nutzung [Common pastures in Southern Bavaria: Conservation through agricultural use]. Angewandte Landchaftsökologie 62. Bundesamt für Naturschutz, Bonn - Bad Godesberg, Germany.

Mantescu, L. (2009) When Globalization Meets Postsocialism-Community-Based Institutions for Managing Forest Commons and the Internationalization of Timber Market in Romania. Discussion paper for the Public University of Navarre.

MARD. (2007) National Rural Development Programme 2007-2013. Government of Romania, Ministry of Agriculture and Rural Development, Bucharest.

Ostrom, E. (2001) Reformulating the Commons. Protecting the Commons: A framework for resource management in the Americas (eds J. Burger, E. Ostrom, R. Norgaard, D. Policansky \& B. Goldstein), pp. 17-41. Island Press, Washington DC.

Page, N., Popa, R., Huband, S., Balan, A. \& Sutcliffe, L.M.E. (2012) Romania. High Nature farming in Europe (eds R. Oppermann, G. Beaufoy \& G. Jones), pp. 346-357. Verlag Regionalkultur, Ubstadt.

Paulini, I., Bărbos, M., Crişan, A., Jitea, I.M., Mihai, V., Moldovan, A., Negoiţă, R., Poledna, R., Rákosy, L., Troc, M. \& Schumacher, W. (2011). Grassland conservation through CAP instruments - A Transylvanian case study. 2010 and 2011 summary report of the Mozaic Project. Cluj-Napoca.

Poschlod, P. \& Wallis De Vries, M.F. (2002) The historical and socioeconomic perspective of calcareous grasslands-lessons from the distant and recent past. Biological Conservation, 104, 361-376.

Reeson, A.F., Rodriguez, L.C., Whitten, S.M., Williams, K., Nolles, K., Windle, J. \& Rolfe, J. (2011) Adapting auctions for the provision of ecosystem services at the landscape scale. Ecological Economics, 70, 1621-1627. 
Rodgers, C.P., Straughton, E.A., Winchester, A.J.L. \& Pieraccini, M. (2011) Contested Common Land: Environmental Governance Past and Present. Earthscan, London.

Roeder, N., Lederbogen, D., Trautner, J., Bergamini, A., Stofer, S. \& Scheidegger, C. (2010) The impact of changing agricultural policies on jointly used rough pastures in the Bavarian Pre-Alps: An economic and ecological scenario approach. Ecological Economics, 69, 2435-2447.

Sikor, T. (2004) The commons in transition: agrarian and environmental change in Central and Eastern Europe. Environmental Management, 34, 270-280.

Smith, P., Bhogal, a., Edgington, P., Black, H., Lilly, A., Barraclough, D., Worrall, F., Hillier, J. \& Merrington, G. (2010) Consequences of feasible future agricultural land-use change on soil organic carbon stocks and greenhouse gas emissions in Great Britain. Soil Use and Management, 26, 381-398.

Theesfeld, I. (2004) Constraints on Collective Action in a Transitional Economy: The Case of Bulgaria's Irrigation Sector. World Development, 32, 251-271.

Wegener, S., Labar, K., Petrick, M., Marquardt, D., Theesfeld, I. \& Buchenrieder, G. (2011) Administering the Common Agricultural Policy in Bulgaria and Romania: obstacles to accountability and administrative capacity. International Review of Administrative Sciences, 77, 583-608.

Wilson, O.J. \& Wilson, G.A. (1997) Common cause or common concern? The role of common lands in the post-productivist countryside. Area, 29, 45-58. 


\section{Chapter 4}

\section{Wood-pasture management in Southern Transylvania (Romania): from communal to where?}

Laura Sutcliffe, Kinga Öllerer and Marlene Roellig

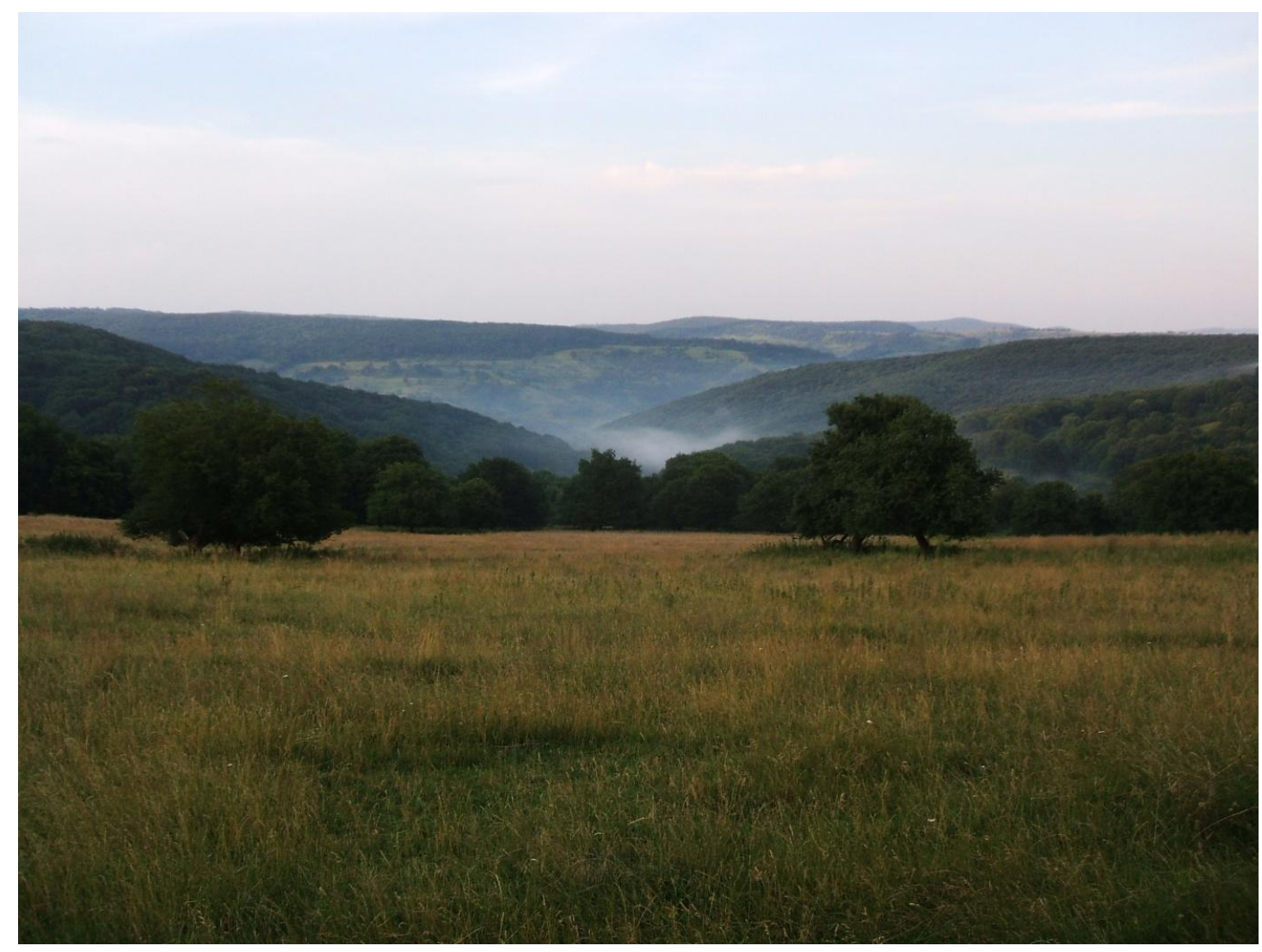

In: European wood-pastures in transition: a social-ecological approach (2014) Eds. T. Hartel \& T. Plieninger. Routledge, Abingdon, UK. 


\section{Introduction}

Wood-pastures developed in many areas of Europe as a shared community resource under the governance of local institutions (e.g. Vera 2000; Chételat et al. 2013). Whilst such communal governance systems have largely disappeared in the north and west of Europe, they remain widespread in Romania today as a means of grassland and forest regulation (Mantescu 2009; Sutcliffe et al. 2013). This chapter considers the communal governance of wood-pastures in the region of Târnava Mare in Southern Transylvania (central Romania), an area rich in wood-pastures that have been important productive elements of low-intensity farming for centuries, and continue to be actively farmed. These wood-pastures are important not only as a means of sustainable agroforestry, supporting both agricultural production and high levels of biodiversity, but as a community resource are also tightly linked to the cultural history of the region. Nevertheless, increasing incidences of felling, burning, changes in management practices and abandonment in recent years evidence the fact that the relevance of woodpastures for local communities is waning and the communal management is failing.

This chapter addresses the question of how the governance of wood-pastures in Târnava Mare can adapt to the current and future needs of the local populations. Based on information from the literature, it describes their historical development and stable communal management in the Saxon communities, as well as the destructive impact of the communist era. The chapter also draws on information from qualitative interviews with 30 commons users and members of the local administration, carried out in the region of Târnava Mare in 2012, to examine the challenges faced by wood-pastures today as Romania enters a new era of agricultural development. It discusses the opportunities provided by commons governance to adapt the use of wood-pastures to meet the changing needs of the local communities, and suggests ways in which associations of farmers can be strengthened in order to provide sustainable management to maintain these wood-pastures into the future. 


\section{Development and structure of wood-pastures in the Târnava Mare area in Southern}

\section{Transylvania}

Târnava Mare is a region of steep-sided valleys and fertile farmland in the south of the Transylvanian plateau, enclosed within the southern arc of the Carpathian Mountains (Figure 1). Ranging from around 500 to $700 \mathrm{~m}$ a.s.l., the potential natural vegetation of the area is temperate continental oak-hornbeam and beech-hornbeam forest (Bohn et al. 2000), which can still be found, albeit somewhat modified, in the forests in the area (Mountford \& Akeroyd 2005). Nevertheless, the vegetation has long been shaped by human management, and centuries of continuous low-intensity management have created a mosaic of species rich habitats, among which the wood-pastures can be included. Although the wider Transylvanian region was settled sporadically by different cultures from the stone age onwards (Gündisch 1998), we know for certain that since around the $13^{\text {th }}$ century the Târnava Mare area has been continuously inhabited by the Transylvanian Saxons (Teşculă \& Goţa 2007). This Germanspeaking ethnic group migrated from present-day Germany and Luxembourg in the $12^{\text {th }}$ and $13^{\text {th }}$ century upon invitation of the Hungarian rulers of Transylvania, and for the next 800 years were the dominant ethnic group in the region.

The Saxons were granted autonomy from the Hungarian rule through the Diploma Andreanum of 1224, giving them the freedom to govern both themselves and the land that they inhabited. This independence allowed them to build up a number of institutions, those at the local scale revolving mainly around forestry, farming and the church. These various institutions provided not only a support network in everyday life, such as the 'Nachbarschaften' (neighbourhoods) within villages, who would collectively help if one household was in need of assistance, but also continuous monitoring of adherence to the rules. If, for example, a woman did not attend church on Sunday without giving a good reason, the absence would be noted by the 'Altschwester' (senior sister) of her 'Schwesterschaft' (sisterhood) and she would have to pay a fine. The same of course applied to the men within their 'Bruderschaft' (brotherhood). With time, the Saxons became renowned for their tightly knit communities and strict rules, as well as their exemplary farming, forestry and land management techniques (Dorner 1910). Grazing in closed canopy woodlands as well as more open pasture with scattered trees - both referred to here as wood-pasture - is likely to have been a farming practice used by the Saxons from the beginning of their settlement, as it was widespread in Europe at that time (Vera 2000). One of the first written records of this activity is a letter from 1583 from the then ruler, Stefan Báthory, King of Poland and Prince of Transylvania. In it, he responds to a request by the Saxons to grant them sole control over the 
grazing of sheep and pigs in the 'lands and the oak forests' of their territory (Oroszi 2004), demonstrating the importance of wood-pasturing to the Saxon community by allowing them to exclude the livestock of outsiders.

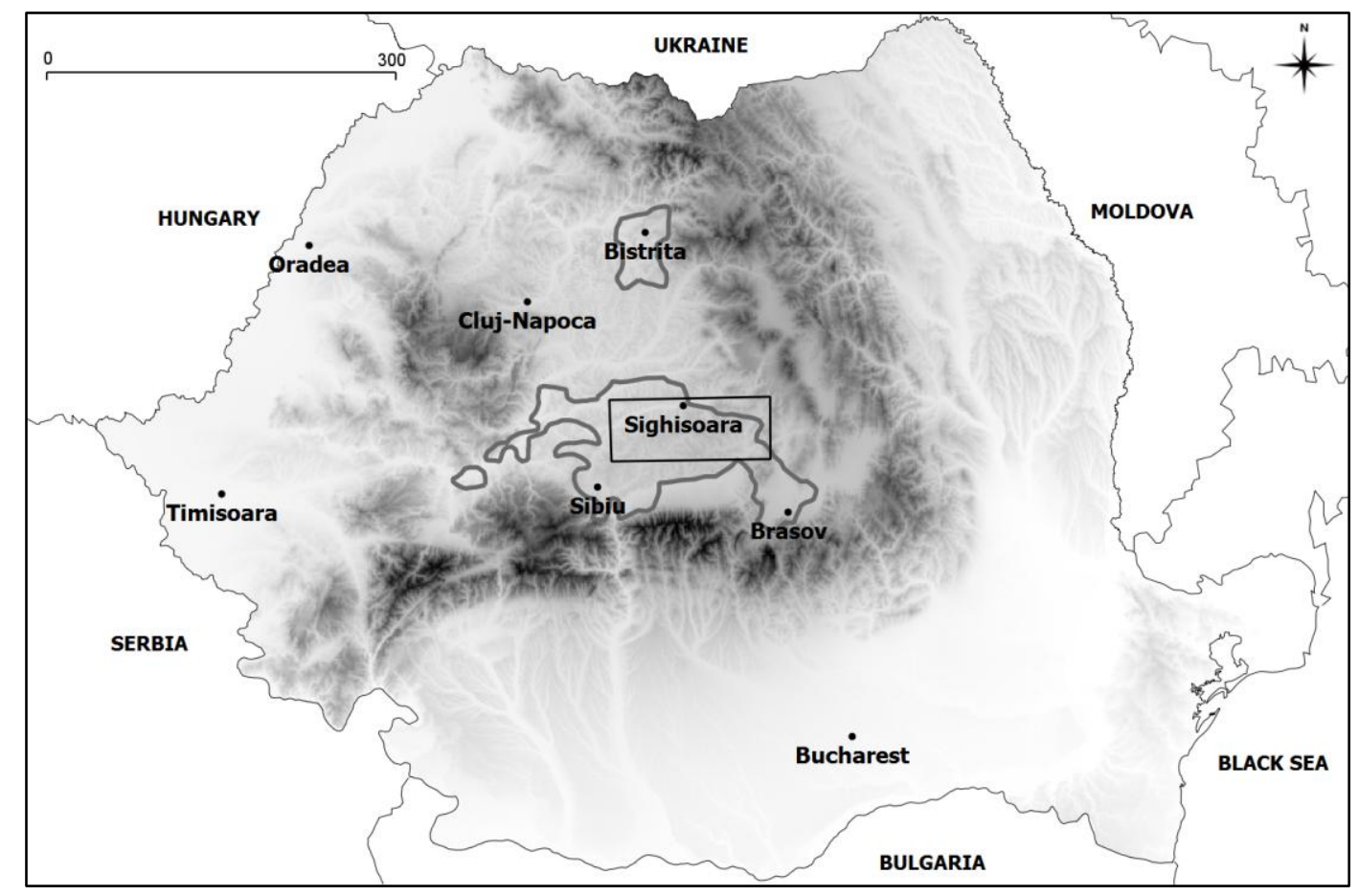

Figure 1 Digital elevation map of Romania showing present-day borders and historical regions predominantly inhabited by Saxon communities (grey outline), based on Gündisch (1998). The location of the Târnava Mare region, an old administrative unit of approx. $850 \mathrm{~km}^{2}$ within the arc of the Carpathian Mountains, is indicated by the black box.

As a primarily subsistence farming community, with each household carrying out a variety of agricultural activities for their own consumption, the Saxon community highly valued woodpastures for livestock grazing. 'Acorn' forests were the most valuable category of forest in medieval Transylvania (Dorner 1910; Makkai 2003), as was also the case in most of Europe at that time (Vera 2000). Oaks were selectively maintained to produce acorns particularly for pig grazing, and the extraction of timber and other products played a lesser role. Oaks (Quercus robur and Q. petraea) still predominate in the wood pastures in the area, but wild fruit trees, beech, hornbeam and sometimes ash also provided fodder and shelter. The natural regeneration in particular of $Q$. robur and $Q$. petraea is facilitated by low-intensity grazing by cattle and pigs (the two main livestock species kept by Saxons), as the saplings of these species do not grow well under a closed canopy, or under close grazing by sheep or goats 
(Vera 2000). The practice of wood pasturing may therefore have played a role in the current distribution of oaks in the region, especially given the frequency of this land-use type. Although only making up around $7 \%$ of total grassland in each municipality today, the majority of villages in the area have at least one wood-pasture, ranging from around 10 to over 450 ha and with an average size of around 100 ha (M. Roellig unpublished data; Figure 2a). Tree density is currently on average 7.6 per hectare in the wood-pastures in the region (Hartel et al.. 2013; see Figure 2b for an example), however, this open nature would not have been typical until about a century ago. In 1853 a law was passed requiring the separation of forest and pasture between landlords and local farmers in the process of decreasing the dependence of serfdom. As an outcome, local farmers lost their rights of free grazing in forests owned by landlords. This, together with the 1879 forestry law which restricted grazing in the forests due to its harmful effects on soil quality and tree regeneration, resulted in the transformation of the traditional forest grazing practices (Saláta, Horváth \& Varga 2009). This led to the opening up of many grazed forest areas, still shown on the $1^{\text {st }}$ Ordnance Survey of the Habsburg Empire (1769-1773) as closed canopy woodland, but recognizable on maps a century later as clearly open pastures but with scattered trees remaining (Öllerer 2013). Land cover depicted on the maps suggest that by the end of the $19^{\text {th }}$ century almost every Saxon village had at least one clearly defined wood-pasture, which was communally used by the inhabitants and governed by the communal authorities (Dorner 1910). The location close to the village - typically only around $1 \mathrm{~km}$ from the centre of the village for the wood-pastures surveyed in a recent study (Hartel \& Moga 2010) - highlights its presence in the daily lives of the local community.

Many of the wood-pastures created by the Saxons in Târnava Mare survive today, as illustrated by the relatively high density shown in Figure 2a. Half of the wood-pasture sites surveyed in a recent study in the area contained veteran trees (sensu Read 2000, i.e. over $2 \mathrm{~m}$ in diameter at breast height, corresponding to an age of >200 years): given the practice of removing oaks from forests before they reach 150 years old, the presence of trees estimated at 400 years or more suggests continuous use as wood-pastures for at least several centuries (Hartel \& Moga 2010). Although there has been no comprehensive inventory of woodpastures at larger scales in Romania, unpublished data suggests that wood-pastures remain a common landscape element throughout Transylvania. 


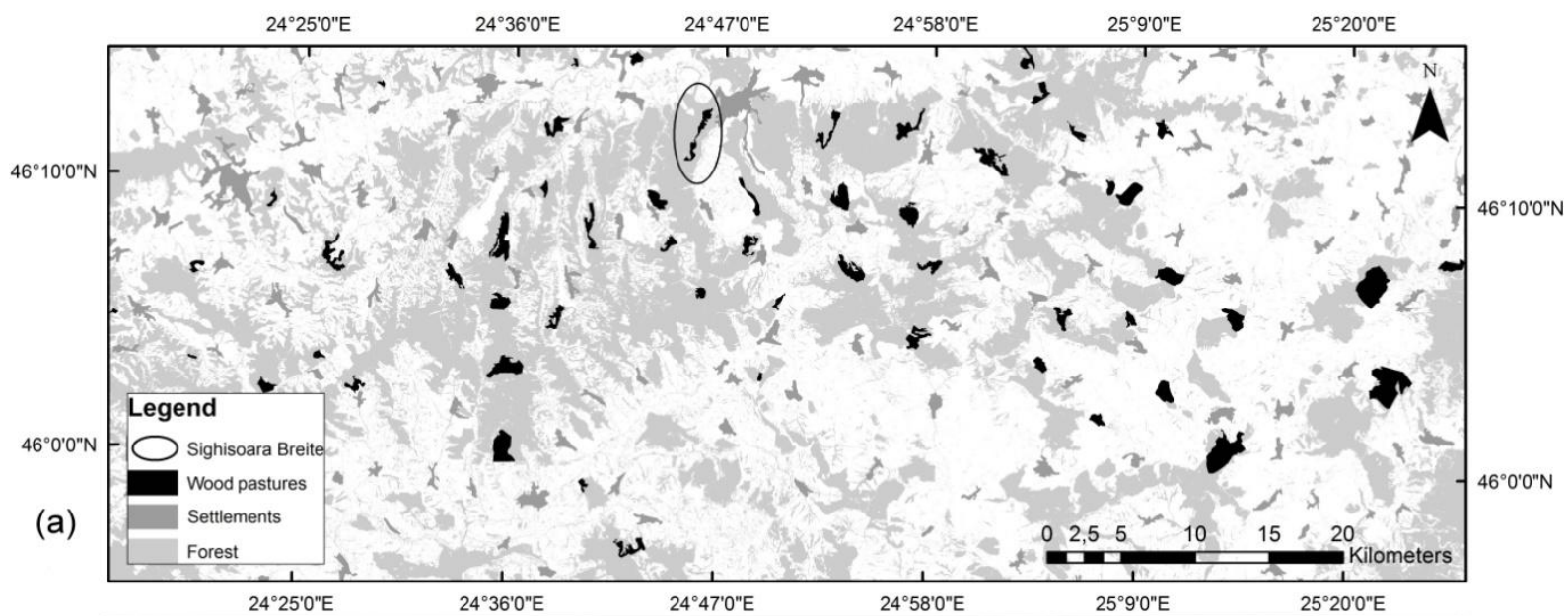

(b)

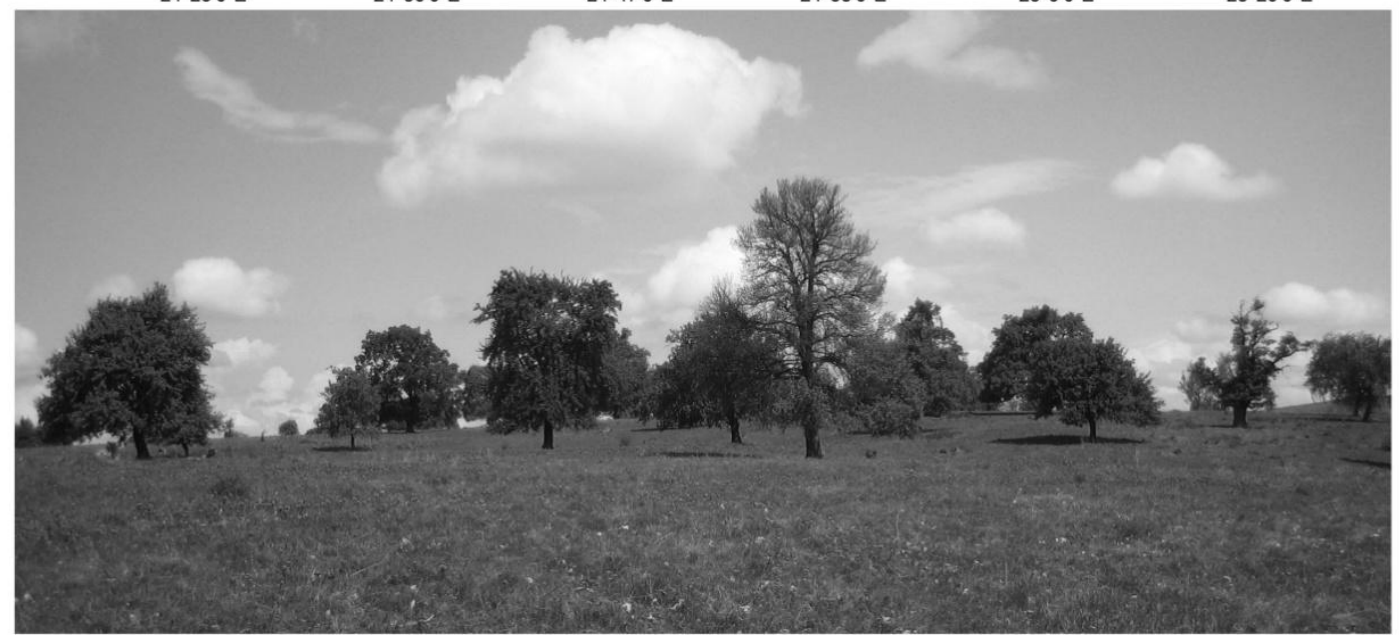

Figure 2 (a) Map of the distribution of 55 of the most representative wood-pastures in the Târnava Mare area, surveyed in a recent study. (b) Photo of a typical wood-pasture with scattered oaks and fruit trees in the village of Mercheaşa (Streitforth) in the Târnava Mare region (M. Roellig 2012).

The presence of scattered veteran trees in wood-pastures provides not only important habitats within the tree itself, but also a variety of vegetation structures that supports both typical forest species such as woodpeckers (Dorresteijn et al. 2013) and brown bears, as well as species of open grassland such as many butterflies (Hartel \& Moga 2010). The best studied of the wood-pastures in the area, the Sighişoara Breite (Figure 2a), has been shown to support 476 species of vascular plants (Öllerer 2012), 40 species of xylophagous beetles 281 species of Lepidoptera 27 species of nesting birds and 38 species of mammals (summarised in Hartel \& Moga 2010). The longer the continuity of use, generally the older and more valuable the trees, and the more species-rich grassland communities become (e.g. Dauber, Bengtsson \& Lenoir 2006; Aavik et al. 2009): in the case of Târnava Mare, long-term sustainable use of wood-pastures was ensured through stable governance by the Saxon communities. 


\section{Wood-pasture governance in the Saxon society}

From the beginning of the Saxon settlements, almost all land within the village boundaries was communal and administered by the village authorities (Nägler, Schobel \& Drotleff 1984). This meant that although the land belonged to the rulers of the time, all members of the village's Saxon community had rights to use these resources. In later centuries, land was also bought by individuals or communities, however the use of the pastures almost always remained a formal legal right for all villagers. This right was linked to a set of rules and responsibilities, overseen by the village authorities, ensuring that all users had the same benefits and costs (see Table 1). Such common management provides a number of labour saving benefits through cooperation: animals were generally herded, so employing a herder to tend a collective herd was more efficient than each farmer taking his own livestock to graze. However, the many challenges for commons governance compared to private use have been extensively discussed, such as the temptation to freeload, i.e. to benefit at the cost of others, or overharvest (see e.g. Olson 1965). For many years, commons systems were thought of as an ineffective and even damaging for resources, however, as demonstrated by Elinor Ostrom in her seminal work on commons governance (Ostrom 1990), stable institutions that are monitored and enforced can provide long-term sustainable management of common resources. Analysing the problems and solutions found by commons governance institutions around the world, Ostrom (1990) developed a number of design principles or core factors shared by long sustained commons regimes. Although not a blueprint for success, these lessons have been reviewed in multiple studies (see e.g. Cox et al. 2010) and shown to hold for most robust resource systems. Table 1 highlights some of the basic characteristics of the Saxon common grazing regime in the context of the design principles in order to demonstrate why it may have been so successful and enduring. 
Table 1 Applying the eight design principles developed by Ostrom (1990) to the Saxon pasture governance system. Information on the Saxon grazing system based on Schuller (1895), Dorner (1910) and Nägler, Schobel \& Drotleff (1984).

\begin{tabular}{ll}
\hline Design Principle & $\begin{array}{l}\text { General characteristics of the historic Saxon common grazing regime from } \\
\text { around the } 16^{\text {th }} \text { to the } 20^{\text {th }} \text { century }\end{array}$
\end{tabular}

\section{Clearly Defined Boundaries}

Different pasture areas were delimited and one herder did not encroach on the other herder's pasture. Village boundaries were respected, although deals could be negotiated between villages to use each other's land. Common grazing was restricted to a certain period over the summer: often between the feast of St. George $\left(24^{\text {th }}\right.$ April) and St. Martin ( $11^{\text {th }}$ November), in order to allow the vegetation to regenerate or to be used for other purposes. Livestock also followed a certain order: first cattle would graze a pasture, then buffalo (after their introduction in the $18^{\text {th }}$ century), then horses, followed by pigs, then sheep and goats. When resources became scarce, sheep and goats were restricted from using the pastures as they caused the most damage to the vegetation.
2. Proportional Equivalence between Benefits and Costs

\section{Collective-Choice} Arrangements
Villagers had to contribute a number of days of pasture maintenance work (removing scrub, repairing water sources etc.) proportional to the number of animals they grazed (e.g. 2 days per cow or 10 sheep per year).

A yearly meeting was held before the grazing season in which all users could discuss and vote on issues concerning the pasture, such as maintenance work to be done, which areas to graze and with how many animals. This was presided over by a grazing committee, whose members were elected from among the users.

4. Monitoring

Pasture maintenance and adherence to rules was monitored by peers, as users were aware of each other's activities, and formally recorded by the grazing committee. As such, infractions were rare.

\section{Graduated Sanctions}

Fines were imposed e.g. for not carrying out maintenance work, equivalent to the cost of paying someone else to do the work. Exclusion from the community was possible for very serious offences.

6. Conflict-Resolution Mechanisms

7. Minimal Recognition of Rights to Organize
Depending on the type of problem, conflicts could be resolved with the help of the grazing committee.

Sole rights to control grazing on pasture and oak forest were awarded to the Saxon community in 1583. The Saxon 'Nationsuniversität' (the 'intact unity' of the Transylvanian Saxons) had political, administrative and judicial autonomy over their community since 1224 .

For resources that are parts of larger systems: 8. Nested Enterprises
Local grazing institutions, under the authority of the mayor, had control over grazing resources at the local level. However, to resolve more far-reaching problems such as the sovereignty over grazing resources, the Saxon 'Nationsuniversität' represented the Saxon community as a whole. 
Not only the congruence with the design principles, but also the fact that communal management of wood-pastures survived so long in the Saxon society, suggests that their commons institutions were robust. This long-term integration through personal involvement, as well as the involvement of predecessors in the management of the land, can lead to such landscape elements developing a cultural significance for the community (Whiteman \& Cooper 2013). There is also evidence for the Saxon wood-pastures that they were not just locations of cooperation and collective action for work, but also for community cultural events. The first record for the 'Skopationsfest' on the wood-pasture next to the historic town of Sighişoara (Schäßburg, in German) is from 1866, although it probably began much earlier, and this festival took place regularly in the month of May up until 1939 (Figure 3a). The name, derived from the Latin 'scopa' meaning broom, probably referred to the practice of pupils bringing brooms to school to clean away the winter dust and was a celebration of the beginning of summer. It seems that scattered trees were clearly present in the Saxon concept of idyllic open landscapes (Figure 3b), but the Sighişoara Breite wood-pasture was a location for celebrations and also general recreational activities for all inhabitants, not just the Saxons (Teşculă \& Goţa 2007).

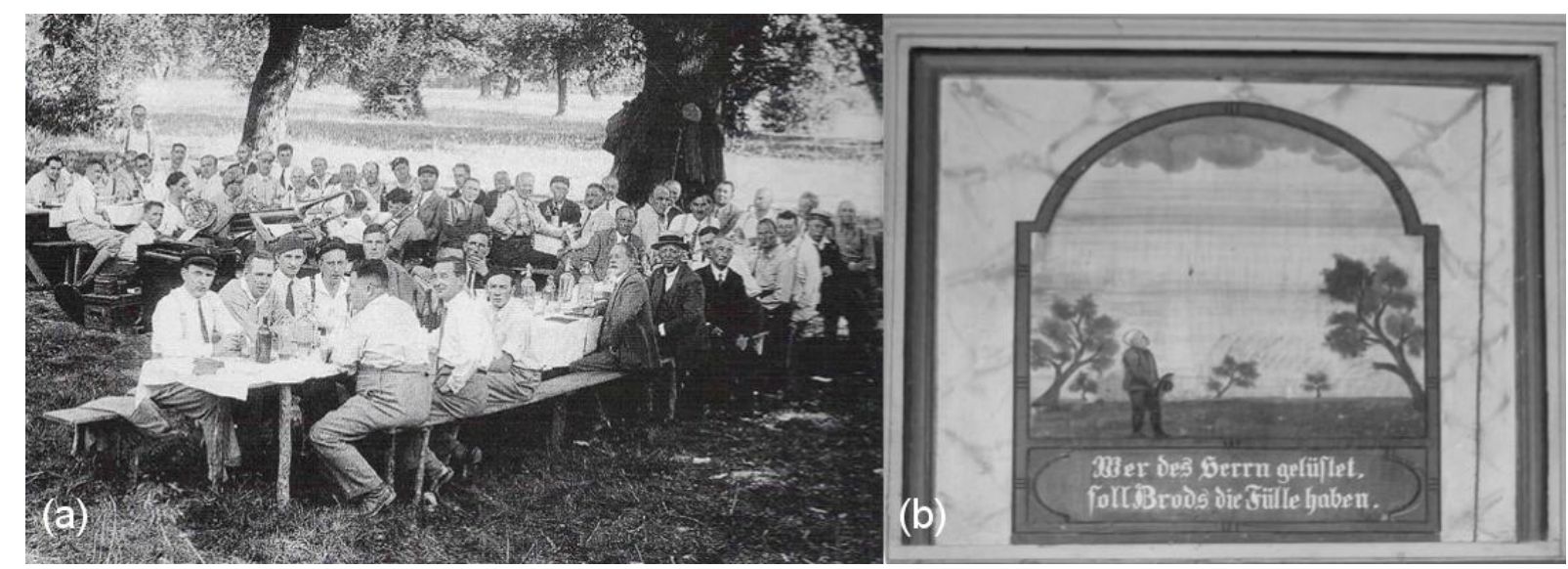

Figure 3 (a) Picture of Skopationsfest on the Sighişoara Breite from the early $20^{\text {th }}$ century (author unknown: from the personal archive of Walter Lingner). (b) Photograph of a painted wooden panel dating from 1776 in the fortified church in the village of Brădeni (Henndorf, Southern Transylvania), showing a pasture with scattered oaks (inscription: "Wer des Herrn gelüstet soll Brods die Fülle haben" - He who hungers for the Lord shall never want for bread. Photo: L. Sutcliffe 2013). 


\section{Communism, post-communism and accession to the European Union}

In the period after 1945, communist rule revolutionised the farming system and obliterated the traditional Saxon governance of the area. Most forest and agricultural land was taken into state ownership, agricultural productivity was significantly intensified in some areas and abandoned in others, and local communities were fragmented and dispersed. For woodpastures, this meant a period of significant change: in some cases clearance and transformation into other forms of land use ("site amelioration"), or development into forest, and for those left as pastures most were taken out of common use and appropriated by state or collective farms.

This period of agricultural intensification was then followed by almost two decades of largescale abandonment following the fall of the communist regime in 1989, as the communist agricultural institutions crumbled (e.g. Kuemmerle et al. 2008). Local institutions for both private and common land management were hindered from reforming, partly by the slow and piecemeal process of returning land to its former owners (restitution), but also by the changes in the local population. Many Saxons had fled persecution by the communist government under Nicolae Ceauşescu, or had been forcibly deported. Those who had been unable or unwilling to leave during the communist era flooded out of the country after 1990, mostly to Germany where they had been offered citizenship by the German government. Within several years of the end of the communist regime, only around 25,000 German-speaking citizens remained in Romania - less than $10 \%$ of the number at the start of the communist period (Gündisch 1998). Their empty houses were occupied by settling Rroma or bought by Romanians, many of whom had moved to the area within their lifetime or only one generation ago.

Although the wood-pastures were largely returned to communal administration, and the grazing committees continued to oversee their use by the community, the link between the people and the land, and the historical significance of the wood-pastures for the local population had been lost. Commons users in the Târnava Mare region interviewed in 2012 recalled a period of chaos, where rules were difficult to enforce in the general disruption following the political changes, and maintenance of pastures was neglected as local authorities struggled to adapt to the loss of central government control. Large solitary trees were, for example, sold for felling to raise money, and many pastures became overgrown with scrub and young trees during the 1990s and early 2000s (M. Roellig, unpublished interview data). 
Romania's accession to the European Union in 2007 was the next key turning point in the fate of its wood-pastures. The introduction of basic requirements for subsidy payments for pastures spurred an upsurge in scrub clearance, and all interviewed commons users reported an increase in pasture maintenance activities to correct the neglect of the previous years. Due to the requirement for a minimum of 5 years entitlement to the land by a legal person (either an individual or a registered association) in order to claim agri-environment scheme payments, the use of the land quickly changed from that of a common to that of a rental system. Today, wood-pastures in the Târnava Mare region may be communally owned, but they will probably be divided into single user parcels rented by individuals. Thus, although the direct sale of state owned common land is technically illegal, a de facto privatization of common land is occurring.

The type of farmer using the communal pasture is also changing. Although Romania still has the highest number of agricultural holdings per capita in the EU (Eurostat 2011), in the last decade the number of subsistence and semi-subsistence farmers, i.e. who produce exclusively or mainly for their own consumption, has been dropping (Eurostat 2009). Such farmers made up the majority of commons users in Saxon times, but with better job opportunities in the cities or abroad, and the poor financial returns from farming, these are being replaced by fewer but larger scale farmers. For the dwindling number of small-scale farmers who do not own enough animals to rent their own parcel, space for a common herd is still provided by the Town Hall or they come to an arrangement with another renter. Nevertheless, many small-scale farmers complained of losing out under the current system to the interests of more powerful actors. Related to this, one interesting development in recent years has been the promotion by the Romanian government of the formation of graziers' associations for small-scale farmers, to collectively rent land for their animals and for which they can claim subsidy money to be used for the benefit of the members (Sutcliffe et al. 2013). These new associations hold the potential to be the commons institutions of the future, superseding the Town Hall governance and forming new rules and norms adapted to the current socio-economic and political conditions.

However, the success of these new associations at self-organizing has been limited. Again, it is useful to consider the problems for the graziers' associations in the context of the commons literature, this time comparing the situation with some of the key threats for sustainable governance systems identified by Ostrom (1994, highlighted in bold in the following). Blueprint thinking tries to apply universal solutions to often locally specific conditions, in much the same way as current requirements for European agricultural subsidy 
payments dictate management parameters that associations must fulfil. For example, the maximum and minimum number of animals allowed per hectare under subsidy schemes applies to the whole country (APIA 2012; MADR 2012), whilst it is generally known that the carrying capacity of pastures can differ substantially from area to area and from year to year. Rapid changes in technology and human populations occurred with the mechanization of agriculture and the changes in farm structures, as well as the dramatic population changes that took place in Romania in the second half of the 20th century. Today the instability continues, with recent and rapid changes in agricultural policy and continuing rural depopulation as challenging factors for institutions to adjust to. The population changes have also led to transmission failures, in which the principles of an effective community-governed institution were not passed down from one generation to another, due to the interruption of the period of collectivization. The changes in technology and farming systems in general have increased the heterogeneity of participants. In Saxon times the commons users were almost exclusively subsistence or semi-subsistence farmers, but now villagers with rights to a communal pasture may own 1, 10 or 100 cows, increasing the heterogeneity of interests represented. Finally, corruption and other forms of opportunistic behaviour were rife in the communist era and are encouraged today by the subsidy money available, leading to a decrease in trust in commons institutions and in willingness to cooperate (Sutcliffe et al. 2013).

In addition to the issues related to access to the common pastures today, the current governance seems to be negatively affecting the ecological value of the wood-pastures. Although generally in a good state, over half those surveyed in Târnava Mare by Hartel \& Moga (2010) were affected by under or occasionally over-grazing. Potentially more serious, however, is the burning (intentional or unintentional) or felling of trees in wood-pastures. Despite the fact that both burning of grassland and the cutting of solitary trees on agricultural land is now prohibited under the cross-compliance requirements for receiving subsidies (unless the tree is certified as being damaged or diseased: MADR 2012), these incidences are increasing (e.g. Rostás 2012a; Rostás 2012b). The disregard for the solitary trees could be partly a result of the changes in livestock patterns: the last known pig grazing in woodpastures - for which the trees were highly important - took place in the region around the 1960s. Although the shade and erosion protection provided by the trees is still mentioned by farmers for their sheep and cattle (T. Hartel, unpublished data), they are no longer perceived as of major value to production. These changes in the farming systems have thus lead to loss of saliency of wood-pastures to local communities, however, it is arguably the demographic changes that have had the greatest impact on wood-pasture management in the region. In 
contrast to the strong links between the Saxon communities and the wood-pastures, these areas are now largely perceived as simply the property of the state, and of little relevance for the local population apart from to the now limited number of farmers that graze them.

\section{Conclusions - from communal to where?}

The wood-pastures in Southern Transylvania were formed and maintained over centuries under communal governance, and their status as a community resource is an important part of their historical identity. The previous sections have described some of the characteristics of the Saxon institutions - such as autonomous control over their resources and effective monitoring systems leading to appropriate sanctions - that may have contributed to their longterm sustainable and productive management of the wood-pastures. As a result, from a conservation perspective, the region in general is currently in the enviable position that it retains a high density of actively used wood-pastures in a species-rich agricultural landscape. The Saxon communities which created them, however, have been irrevocably lost, and their institutions damaged by decades of political and social upheaval. Recent developments suggest that the future of the wood-pastures is not assured, and unstable governance increases susceptibility to threats such as abandonment and illegal felling. Given the considerable recent changes in the socio-economic, agricultural, political and demographic conditions in the region, the question thus arises as to whether the practice of common management is still fit for purpose today?

The drastic decline in the number of common grazing systems in northern and western Europe since the $18^{\text {th }}$ century has led to the perception that commons are now an anachronistic concept, and European agricultural policy is designed with single-user management in mind, further disadvantaging the remaining commons systems (Brown 2006). The trend towards individual management of the commons in Târnava Mare could be seen as a way to provide more streamlined management as subsistence farming is replaced by fewer, larger farmers. However, whilst privatization can doubtless in some cases provide appropriate and careful management for wood-pastures, the relative ease of decision making by single users could rapidly lead to stark and irrevocable changes in land use, such as the removal of veteran trees. The legal status of commons (i.e. that decisions require the consent of multiple stakeholders), on the other hand, provides them with inertia against changes in management practices (Wilson \& Wilson 1997). 
Communal governance does not of course ensure good management per se: indeed, in the Târnava Mare area it has recently been responsible for poor conditions (over and undergrazing, damage to trees, erosion etc.) in many wood-pastures. However, as has been repeatedly demonstrated, modern management of common pool resources can be sustainable and successful under a variety of conditions if strong institutions exist (Ostrom 1990). By considering the current commons institutions in the context of knowledge about successful commons governance systems, including the Saxon governance, it is possible to identify areas for improvement. For example, providing the graziers' associations with greater central support in organization and administration, and measures to reduce corruption, would improve their robustness and capacity. Farmer associations are already seen as a priority in Romanian agricultural policy and the main tool for their support is funding to improve their competitiveness through several measures of the national Rural Development Plan (Luca \& Toderiţă 2012). However, this has not helped many associations to form, and uptake of these funds is still very low in Romania, due partly to the relatively large bureaucratic demands of these measures (Luca \& Toderiţă 2012). In the study area, it seems particularly a lack of knowledge and trust in associations at the local level is hindering them from forming in the first place. Better use of the provisions for training and information measures in the CAP could help alleviate this.

If successful, such local associations could also in turn play a role in developing such trust and community involvement in formal organizations, which is currently relatively low in Romania and eastern Europe as a whole (Pichler \& Wallace 2007). Furthermore, they hold the potential to support the remaining small-scale farmers to adapt their production to the current agricultural conditions. Collective action through associations allows better exploitation of agricultural subsidies and marketing opportunities, as has been seen in the few positive examples of associations in the Târnava Mare region (Sutcliffe et al. 2013). Networks of associations would also help to overcome the poor dissemination of information related to agricultural practices and regulations in Romania (Fox 2010; Wegener et al. 2011; Mikulcak et al. 2013) by providing advice and expertise to smallholders. This kind of activity could help to increase the profitability of, and access to, the wood-pastures for the local communities again. Improving future prospects in the area is an important step towards providing the much needed economic stability for people to think long term and use their resources sustainably.

To ensure the future of wood-pastures in Târnava Mare, a number of approaches are needed, including single-user management, or dedicated conservation management such as the 
Sighişoara Breite. Nevertheless, commons governance still holds the potential to provide good management for the majority wood-pastures, which is adaptable to local needs and interests, and can reintegrate them with local communities. In contrast to single-user systems, it can also contribute to community cohesion through cooperation, providing a sense of place in communities that have experienced significant social upheaval and have lost to a large extent their link with the landscape. As an area currently undergoing a relatively rapid shift in socio-economic conditions, this case study illustrates the need for such 'traditional' landscape elements to adapt to the current context, as they have also done in the past (Fischer, Hartel \& Kuemmerle 2012). This means not attempting to preserve the past, nor abandoning woodpastures or common management, but transforming the use of wood-pastures though adaptive management. Strengthening of graziers' associations to provide a voice for small farmers, and support for the diversification of marketing strategies and use of subsidies can provide direct incentives for sustainable use into the future.

\section{Acknowledgements}

The authors are very grateful to Erika Schneider and Claudia Bieling for helpful comments on the text, as well as Fundaţia ADEPT Transilvania, the Mihai Eminescu Trust, and the Alexander von Humboldt Foundation for supporting fieldwork (M.R.).

\section{References}

Aavik, T., Jõgar, Ü., Liira, J., Tulva, I. \& Zobel, M. (2009) Plant diversity in a calcareous wooded meadow - The significance of management continuity. Journal of Vegetation Science, 19, 475-484.

APIA. (2012) Plăţi Pe Suprafaţă 2012 [Single Area Payments 2012]. Ministerul Agriculturii şi Dezvoltării Rurale, Agenţia de Plăţi şi Intervenţie pentru Agricultură, Bucharest. Available at: http://www.apia.org.ro/materiale promovare/Brosura Axa II.pdf.

Bohn, U., Gollub, G., Hettwer, C. \& Weber, H. (2000) Map of the Natural Vegetation of Europe. Federal Agency for Nature Conservation, Bonn.

Brown, K.M. (2006) Common land in Western Europe: anachronism or opportunity for sustainable rural development? IASCP Europe Regional Meeting: Building the European Commons: from Open Fields to Open Source Brescia - Italy.

Chételat, J., Kalbermatten, M., Lannas, K.S.M., Spiegelberger, T., Wettstein, J.-B., Gillet, F., Peringer, A. \& Buttler, A. (2013) A Contextual Analysis of Land-Use and Vegetation 
Changes in Two Wooded Pastures in the Swiss Jura Mountains. Ecology and Society, 18, 39.

Cox, M., Arnold, G. \& Villamayor Tomás, S. (2010) A Review of Design Principles for Community-based Natural Resource Management. Ecology and Society, 15, 38.

Dauber, J., Bengtsson, J. \& Lenoir, L. (2006) Evaluating Effects of Habitat Loss and LandUse Continuity on Ant Species Richness in Seminatural Grassland Remnants. Conservation Biology, 20, 1150-1160.

Dorner, B. (1910) Az Erdélyi Szászok Mezögazdasága [The Agriculture of the Transylvanian Saxons]. Győr, Hungary.

Dorresteijn, I., Hartel, T., Hanspach, J., von Wehrden, H. \& Fischer, J. (2013) The Conservation Value of Traditional Rural Landscapes: The Case of Woodpeckers in Transylvania, Romania. PLoS One, 8, e65236.

Eurostat. (2009) Farm Structure Survey in Romania - 2007. European Commission, Brussels. http://epp.eurostat.ec.europa.eu/cache/ITY_OFFPUB/KS-SF-09-080/EN/KS-SF-09-080EN.PDF. [Accessed 20.07.2012].

Eurostat. (2011) Eurostat Yearbook 2011. European Commission, Brussels. http://epp.eurostat.ec.europa.eu/portal/page/portal/product_details/publication?p_product _code=KS-CD-11-001. [Accessed 20.07.2012].

Fischer, J., Hartel, T. \& Kuemmerle, T. (2012) Conservation policy in traditional farming landscapes. Conservation Letters, 5, 167-175.

Fox, K. (2010) Peasants into European Farmers? EU Integration in the Carpathian Mountains of Romania (ed C Giordano). Lit Verlag, Berlin.

Gündisch, K. (1998) Siebenbürgen Und Die Siebenbürger Sachsen [Transylvania and the Transylvanian Saxons]. Studienbuchreihe der Stiftung Ostdeutscher Kulturrat 8, München.

Hartel, T., Dorresteijn, I., Klein, C., Máthé, O., Moga, C.I., Öllerer, K., Roellig, M., von Wehrden, H. \& Fischer, J. (2013) Wood-pastures in a traditional rural region of Eastern Europe: Characteristics, management and status. Biological Conservation, 166, 267-275.

Hartel, T. \& Moga, C. (2010) Manual de Bună Practică În Managementul Habitatelor de Pajişte Cu Arbori Seculari (Good-Practice Guidebook for the Management of WoodPasture Habitats with Veteran Trees). Mihai Eminescu Trust, Sighişoara, Romania.

Kuemmerle, T., Müller, D., Griffiths, P. \& Rusu, M. (2008). Land use change in Southern Romania after the collapse of socialism. Regional Environmental Change, 9, 1-12.

Luca, L. \& Toderiţă, A. (2012). Why isn't agricultural association attractive? Romanian Center for European Policies (CRPE Policy Brief nr. 14), Bucharest. 
MADR. (2012) Ghidul Fermierului Privind Eco-Conditionalitatea (conformitatea Incrucisata) [Guide for Farmers on Cross-Compliance]. Ministerul Agriculturii Şi Dezvoltării Rurale: Agenţia de Plăţi şi Intervenţie pentru Agricultură, Bucharest.

Makkai, G. (2003) Az Erdelyi-Mezöség Tájökológiája [The Landscape Ecology of the Transylvanian Plain]. Mentor Kiadó, Târgu Mureş, Romania.

Mantescu, L. (2009) When Globalization Meets Postsocialism- Community-Based Institutions for Managing Forest Commons and the Internationalization of Timber Market in Romania. Discussion paper for the Public University of Navarre.

Mikulcak, F., Newig, J., Milcu, A.I., Hartel, T. \& Fischer, J. (2013) Integrating rural development and biodiversity conservation in Central Romania. Environmental Conservation, 40, 129-137.

Mountford, O.J. \& Akeroyd, J.R. (2005) A Biodiversity Assessment of the Saxon Villages Region of Transylvania (Romania). Transylvanian Review of Systematic Ecological Research, 2, 31-42.

Nägler, T., Schobel, J. \& Drotleff, K. (1984) Geschichte Der Siebenbürgisch-Sächsischen Landwirtschaft [History of Transylvanian Saxon Agriculture]. Kriterion Verlag, Bucharest.

Öllerer, K. (2012) The flora of the Breite wood pasture (Sighişoara, Romania). Brukenthal Acta Musei, 7, 589-604.

Öllerer, K. (2013) The vegetation of the Breite wood-pasture (Sighişoara , Romania) History, current status and prospects. Brukenthal Acta Musei, 8, 547-566.

Olson, M. (1965) The Logic of Collective Action: Public Goods and the Theory of Groups. Harvard University Press, Cambridge, Mass.

Oroszi, S. (2004) Az erdélyi szászok erdőgazdálkodása (The forest management of the Transylvanian Saxons). Erdészettörténeti közlemények, 63, 1-153.

Ostrom, E. (1990) Governing the Commons: The Evolution of Institutions for Collective Action. Cambridge University Press, New York.

Ostrom, E. (1994) Institutional analysis, design principles and threats to sustainable community governance and management of commons. Community management and common property of coastal fisheries in Asia and the Pacific: concepts, methods and experiences (ed R.S. Pomeroy), pp. 34-50. ICLARM Conf. Proc. 45.

Pichler, F. \& Wallace, C. (2007) Patterns of Formal and Informal Social Capital in Europe. European Sociological Review, 23, 423-435.

Read, H. (2000) Veteran Trees: A Guide to Good Management. English Nature, Peterborough. http://publications.naturalengland.org.uk/publication/75035. [Accessed 20.07.2012]. 
Rostás, Sz. (2012a) Tarlótüzek: egyre égetőbb a helyzet [Wasteland fires: an increasingly burning situation]. Krónika.

Rostás, Sz. (2012b) Tűzvész az öregtölgyesben: ötven fa vált a lángok martalékává a Breite természetvédelmi területen [Fire in the ancient forest reserve: 50 trees devoured by fire in the Breite nature reserve]. Krónika.

Saláta, D., Horváth, S. \& Varga, A. (2009) Az erdei legeltetésre, a fás legelők és legelőerdők használatára vonatkozó 1791 és 1961 közötti törvények [Laws regulating grazing in forests, use of grazed forests and wood pastures in Hungary between 1791 and 1961]. Tájökológiai Lapok, 7, 387-401.

Schuller, G.A. (1895) Aus der Vergangenheit der Siebenbürgen-Sächsischen Landwirtschaft [From the history of the Transylvanian Saxon agriculture]. Buchbruderei W. Krafft, Sibiu, Romania.

Sutcliffe, L., Paulini, I., Jones, G., Marggraf, R. \& Page, N. (2013) Pastoral commons use in Romania and the role of the Common Agricultural Policy. International Journal of the Commons, 7, 58-72.

Teşculă, N. \& Goţa, N. (2007) Istoria ariei protejate [The history of the protected area]. Planul de management al rezervaţiei "Stejarii seculari de la Breite". (ed Mihai Eminescu Trust), pp. 51-55. Sighişoara, Romania.

Vera, F.W.M. (2000) Grazing Ecology and Forest History. CABI Publishing, Wallingford, UK.

Wegener, S., Labar, K., Petrick, M., Marquardt, D., Theesfeld, I. \& Buchenrieder, G. (2011) Administering the Common Agricultural Policy in Bulgaria and Romania: obstacles to accountability and administrative capacity. International Review of Administrative Sciences, 77, 583-608.

Whiteman, G. \& Cooper, W.H. (2013) Ecological Embeddedness. The Academy of Management Journal, 43, 1265-1282.

Wilson, O.J. \& Wilson, G.A. (1997) Common cause or common concern? The role of common lands in the post-productivist countryside. Area, 29, 45-58. 


\section{Chapter 5}

\section{Harnessing the biodiversity value of Central and Eastern European farmland}

Laura M. E. Sutcliffe, Péter Batáry, Urs Kormann, András Báldi, Lynn V. Dicks, Irina Herzon, David Kleijn, Piotr Tryjanowski, Iva Apostolova, Raphaël Arlettaz, Ainars Aunins,

Stéphanie Aviron, Ligita Baležentienė, Christina Fischer, Lubos Halada, Tibor Hartel, Aveliina Helm, Iordan Hristov, Sven D. Jelaska, Mitja Kaligarič, Johannes Kamp, Sebastian Klimek, Pille Koorberg, Jarmila Kostiuková, Anikó Kovács-Hostyánszki, Tobias Kuemmerle, Christoph Leuschner, Regina Lindborg, Jacqueline Loos, Simona Maccherini, Riho Marja, Orsolya Máthé, Vânia Proença, José Rey-Benayas, F. Xavier Sans, Charlotte Seifert, Jarosław Stalenga, Johannes Timaeus, Péter Török, Chris van Swaay, Eneli Viik, Teja Tscharntke

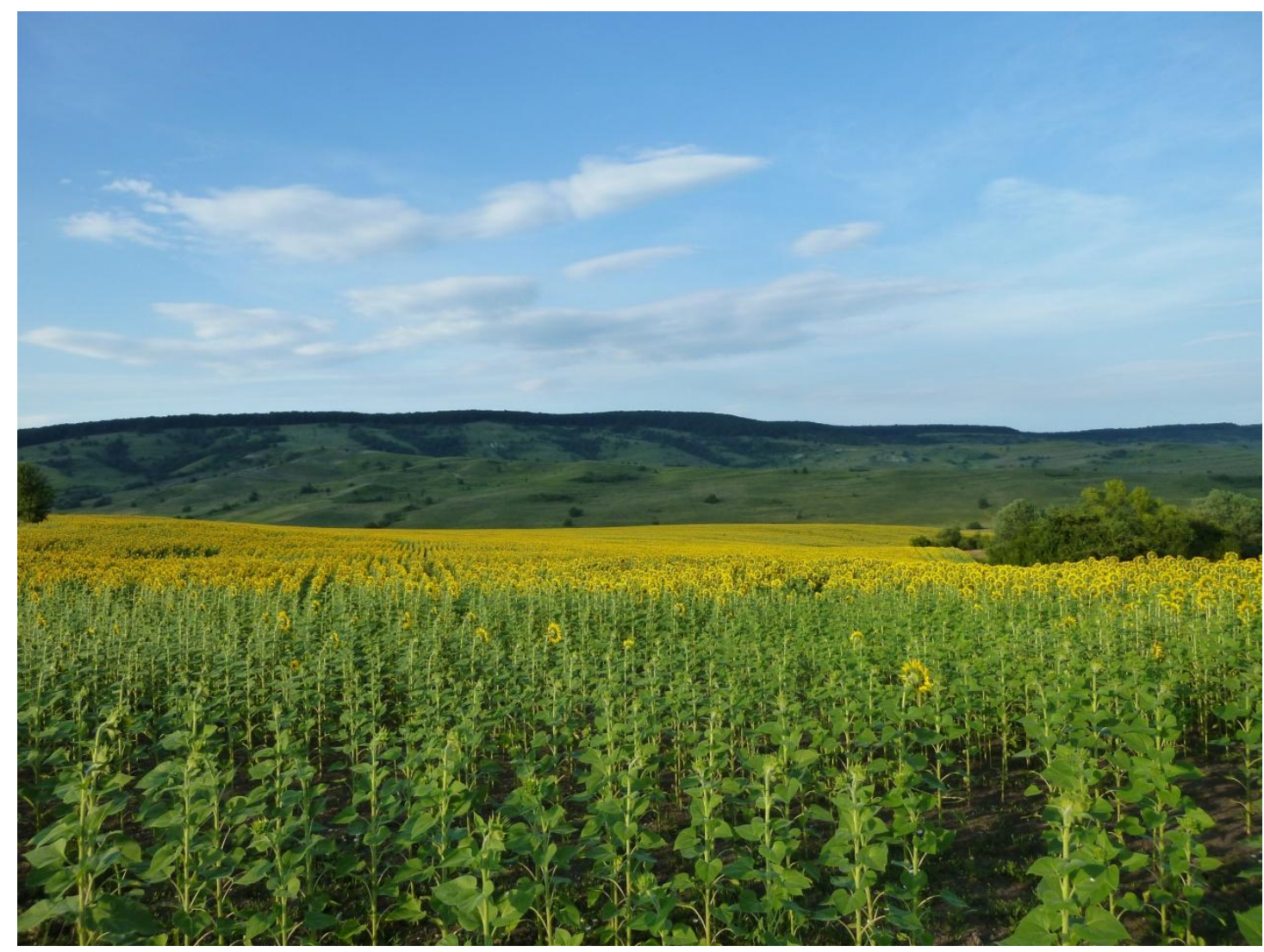

Submitted 


\begin{abstract}
A large proportion of European biodiversity today depends on habitat provided by lowintensity farming practices, yet this resource is continuing to decline as European agriculture intensifies. Within the European Union, particularly the central and eastern new member states have retained relatively large areas of species-rich farmland, but despite increased investment in nature conservation here in recent years, farmland biodiversity trends appear to be becoming increasingly negative. Although the high biodiversity value of Central and Eastern European farmland has long been reported, the amount of research in the international literature focused on farmland biodiversity in this region remains comparatively tiny, and measures within the EU Common Agricultural Policy are relatively poorly adapted to support it. In this opinion paper we argue that, 10 years after the accession of the first eastern EU new member states, the continued underrepresentation of the low-intensity farmland in Central and Eastern Europe in the international literature and EU policy is impeding the development of sound, evidence-based conservation interventions. Harnessing the benefits of the existing low-intensity agriculture in Central and Eastern Europe through targeted research and monitoring to create more locally appropriate conservation strategies should be made a priority in Europe.
\end{abstract}

Keywords: Agricultural intensification; Agri-environment schemes; Common Agricultural Policy; European Union; High Nature Value Farmland 


\section{Introduction}

The long history of low-intensity agricultural land use in Europe has created many unique and species-rich assemblages, and a large proportion of what are generally considered wild European species are now dependent over much of their ranges on this form of human disturbance (Bignal, 1998). However, the industrialization and mechanization of agriculture has, directly and indirectly, caused a dramatic impoverishment of the fauna and flora compared to the situation a century ago (Gregory et al., 2005; Tscharntke et al., 2005; Storkey et al., 2012). This has contributed not only to the current biodiversity crisis in Europe as a whole, but also to the decline in ecosystem services such as crop pollination and biological pest control (Tscharntke et al., 2005). As a result, the protection of farmland biodiversity has become a key issue in EU and national agricultural and environmental policies, and large amounts of research and funding are devoted to biodiversity conservation approaches such as agri-environment schemes (Farmer et al., 2008).

Whilst many conservation schemes play an important role in mitigating the impacts of intensive farming, the support of low-intensity practices on existing High Nature Value (HNV) farmland is, in the short and medium term, the most (cost-)effective way to stop the decline of many specialist species and species-rich communities (Bignal \& McCracken, 1996; Kleijn et al., 2009). HNV farmland is present throughout Europe, although it is often restricted to upland or other areas difficult to farm, particularly in Northern and Western Europe (EEA, 2004a). Eastern and Southern Europe, in contrast, generally have lower average levels of land-use intensity, and healthy populations of many species declining or endangered in the north-west persist here (EEA, 2004b; Liira et al., 2008; Stoate et al., 2009; Báldi \& Batáry, 2011; Tryjanowski et al., 2011). Whilst several decades of EU membership have already contributed to the larges-scale loss of semi-natural farmland habitats in lowland Northern and Western Europe (as well as the Mediterranean and several mountain ranges such as the Alps) (e.g. Donald et al., 2001; Stoate et al., 2009; Rego et al., 2013; Andrey et al., 2014), the central and eastern new member states (NMS) have only relatively recently started implementing EU biodiversity-related and agricultural policies. In this opinion paper, we focus on these central and eastern NMS, arguing that their agricultural systems differ from those in the rest of Europe, particularly the north and west. However, these differences are still poorly represented in EU farmland conservation research and policy, leading to ineffective or even detrimental conservation actions in these countries. 


\section{The legacy of communist agriculture in Central and Eastern Europe and its implications for farmland biodiversity}

Between 2004 and 2013, 11 countries from post-communist Central and Eastern Europe joined the EU in a phased enlargement process that brought it to 28 member states, sharing common policies and goals (see Fig. 1a). Although heterogeneous in many respects, a shared characteristic of the central and eastern NMS is the legacy of communist agricultural policy during the mid and late 20th century, affecting not only on the structure and use of farmland, but also, in turn, farmland biodiversity (Báldi \& Faragó, 2007; Liira et al., 2008). In the western EU-15, and particularly countries such as the UK, France, Germany and the Netherlands, the intensification of lowland farmland was relatively effective, carried out mainly by family farms and driven by production-linked agricultural subsidies. In contrast, the state-imposed homogenization and intensification of farmland in Central and Eastern Europe had severe negative impacts on biodiversity in places, but these were often mitigated by many remaining neglected patches of semi-natural land (Young et al., 2007). Collectivization of land in most Central and Eastern European countries also merged many private smallholdings into industrial farms of up to several thousand hectares in size. After the fall of the communist regimes around 1990, much of this land was returned to private ownership by individuals, but this had a lasting effect of creating a predominance of small semi-subsistence holdings (generally $<5$ ha in size), contrasted with few but very large industrial farms (Fig. 2a; Davidova et al., 2012).

Production dropped dramatically in the east and large areas of both cropland and grassland were abandoned in the 1990s and early 2000s, both of which allowed at least short-term population recoveries of many species (Donald et al., 2001; Keišs, 2003; Stoate et al., 2009; Kamp et al., 2011, but see e.g. some negative effects of farmland abandonment in Hungary documented by Verhulst et al., 2004). In the EU-15 during the same period, farming intensity was maintained but with increasing regulation of environmental impacts, most notably through successive reforms of the EU Common Agricultural Policy (CAP) (see Fig. 2b,c; Stoate et al., 2009). 

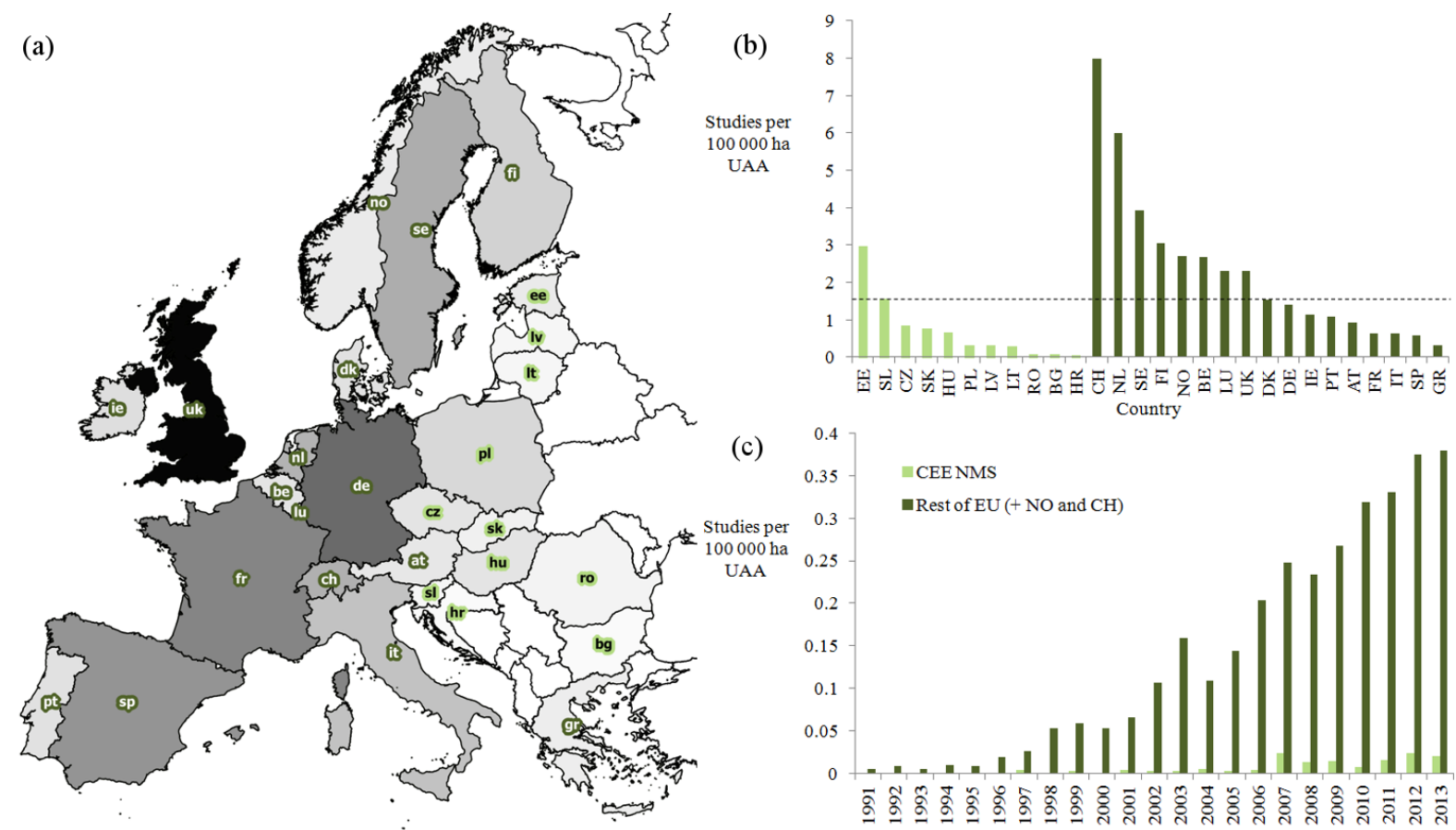

(c)

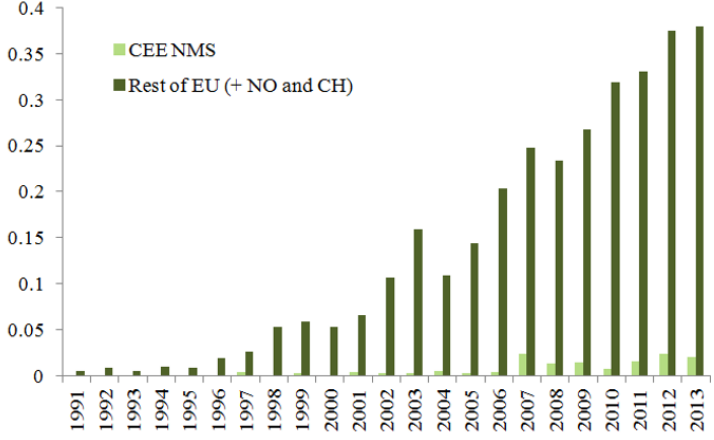

Figure 1 (a) Map of Europe depicting the total number of studies carried out in each EU country found in a search of the Web of Science database. A larger number of studies is indicated by a darker shade of grey (numbers given in Table S1). Light green labels = Central and Eastern European new EU member states (CEE NMS), dark green labels = rest of EU + Norway and Switzerland. We have included the results for Norway and Switzerland, here grouped with the "old" member states due to the similarities of their agricultural systems. Details of the search are given in Appendix S1 and results and country codes in Table S1. (b) Number of studies per 100000 ha utilized agricultural area (UAA) carried out in each EU country (+ Norway and Switzerland) between 1991-2013. The dotted line depicts the average number of studies per country. (c) Number of studies per 100000 ha UAA carried out in CEE new member states compared to the rest of the EU (+ Norway and Switzerland) in each year since 1991.

Through the funding structures of the EU CAP, as well as the influence of the EU market, the central and eastern NMS have experienced both large-scale reactivation and intensification of farmland since accession, and continuing abandonment (Stoate et al., 2009; Tryjanowski et al., 2011; Sanderson et al., 2013). Nevertheless, fragmentation is still a major hindrance in many NMS to the intensification of land use (Hartvigsen, 2014), and convergence of the agricultural sectors of old and new member states is limited (Csáki \& Jámbor, 2013). Thus, compared to Northern and Western Europe, the NMS can be said to have: i) lower levels of agrochemical inputs, mechanization and productivity, with yields less than half those of the 
EU-15 (Csáki \& Jámbor, 2013; see also Fig. 2b,c); ii) farm structures polarized between a small number of very large industrial units and a large number of very small units (Fig. 2a); and iii) a predominance of subsistence and semi-subsistence farming, which is linked with positive effects on biodiversity via its promotion of mixed farming and mosaic structures (Tryjanowski et al., 2011; Davidova et al., 2013).

These are all major reasons why comparative studies show greater ecosystem quality in the NMS (Reidsma et al., 2006), as well as higher levels of rare species occurrence and species richness in lowland farmland than in Northern and Western Europe (Batáry et al., 2010), and large areas of semi-natural vegetation (EEA, 2004b). However, this also means that nutrient limited yield gaps are currently larger in Eastern than in Western Europe (Mueller et al., 2012), so that the potential to intensify in the NMS is high. Whilst farmland biodiversity declines now appear to be slowing for some taxa in Northern and Western Europe, with stronger species richness losses in the mid to late twentieth (Carvalheiro et al., 2013), the picture may be different in the NMS. For example, long-term monitoring trends in farmland birds suggest that their decline has been steeper in the NMS in recent years. The farmland bird index in Bulgaria was $17 \%$ lower in 2010 compared to 2008, i.e. the two years following accession to the EU, after a period of relative stability 2005-2008 (Hristov, 2011). A similar decline was found in Hungary following its accession (HCSO, 2012), as well as in Latvia (Aunins \& Priednieks, 2009) and Poland (Sanderson et al., 2013), linked to the changes in agricultural practices provoked by EU policy. General trends are difficult to measure due to the lack of standardised monitoring data from this region (notable exceptions being the PanEuropean Common Bird Monitoring Scheme; Voříšek et al., 2010, and in some countries the European Butterfly Monitoring Scheme; van Swaay \& Warren, 2012), as well as time lags in species responses (Kuussaari et al., 2009; Dullinger et al., 2013). Nevertheless, the current measures that have been recently put in place to preserve farmland habitats in Central and Eastern Europe seem to be insufficient to counteract the drivers of species loss. 
(a)
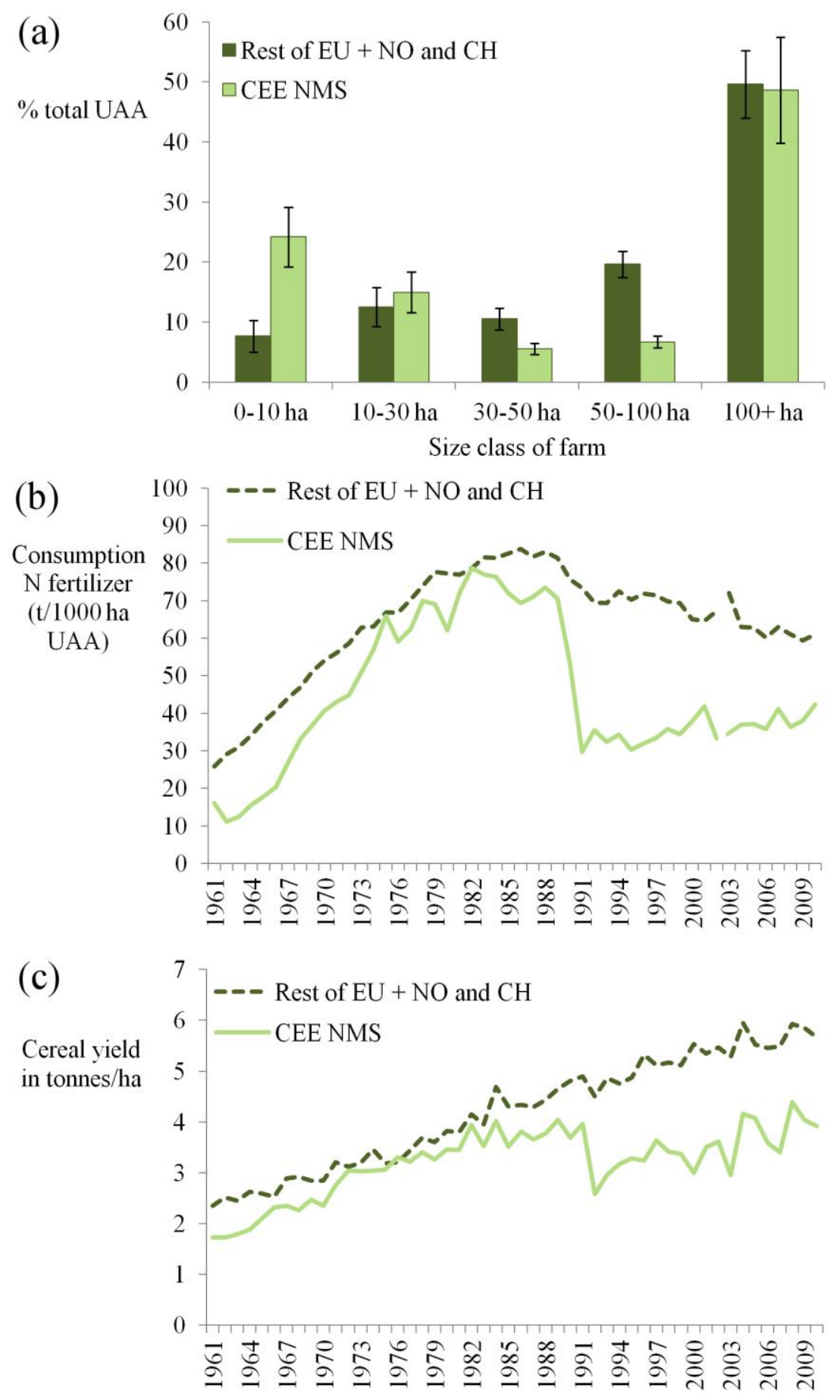

Figure 2 Indices of agricultural intensity in the Central and Eastern EU new member states (CEE NMS), and the rest of the EU (+ Norway and Switzerland). (a) Distribution of farmland area (UAA) according to size classes of farms in 2010 (Eurostat 2013) showing standard error bars. (b) Consumption of $\mathrm{N}$ fertilizer in tonnes per 1000 ha utilized agricultural area (UAA) between 1961 and 2010 for CEE NMS and the rest of the EU (+ NO and CH) (FAOSTAT 2013). The categorization N fertilizer changes slightly in 2002, therefore difference between the years 2002 and 2003 are not comparable. (c) Cereal yield in tonnes per ha (FAOSTAT 2013). For FAOSTAT data, countries included in each category vary according to data availability, and excluding countries with incomplete data did not affect trends. 


\section{Agricultural habitats in Central and Eastern Europe are underrepresented in the international literature}

The ecological literature on European farmland biodiversity has grown steadily in the last two decades, and plays an important role not only in providing locally relevant evidence to feed into conservation management, but also large scale international reviews and meta-analyses to synthesise current knowledge on a topic of interest (Dicks et al., 2013). Searching the online data base Web of Science for peer-reviewed publications produced to date on farmland biodiversity in EU countries yielded 1952 studies published since 1991 (see Appendix S1 in Supporting Information). However, Northern and Western Europe dominates the literature both in terms of absolute number of studies (Fig. 1a; the UK, for example, is the focus of twice as many publications as the central and eastern EU NMS together), and proportional to the agricultural area (Fig. 1b).

Whilst the number of studies from central and eastern NMS is increasing, even when adjusted for the agricultural area in the region they are still only the focus of a tenth of the number of studies focussed on the rest of Europe (Fig. 1c). This confirms the results of a recent literature review on European AES, in which only 3\% focussed on the NMS (Uthes \& Matzdorf, 2013), despite the fact that AES have been in place in most NMS for at least 4 years by the end of the analysed time period. A logical reason for the disparity is the percieved urgency of farmland biodiversity loss, or the amount of research funding available, although the acceptance rate by journals of Eastern European papers has also been criticized (e.g. Rotter \& Gostincar, 2014). Nevertheless, whilst it can be assumed that much ecological research from the NMS is also published in non-English language or regional journals, these are usually not detected by the international community or when creating large scale reviews. This limits the accuracy of conclusions drawn from the literature both for general understanding of farmed ecosystems and for the local design of conservation measures, as species responses can be context specific. For example, moderate intensification was found to have a positive effect on corn bunting populations in a study in Poland (Szymkowiak et al., 2014), compared to the strong evidence for the negative effects of intensification from the UK (Perkins et al., 2011), probably due to the generally low level of intensification in the surrounding Polish landscape. For similar reasons, red-backed shrikes were found to have generally low site fidelity in Polish landscapes, compared to their high site fidelity found in Western Europe (Tryjanowski et al., 2011). 


\section{Harnessing the biodiversity value of Central and Eastern European farmland}

In terms of support measures for farmland biodiversity in the EU, the CAP has by far the greatest influence. With an average payment of $237 € /$ ha of farmland in the last programming period (Farmer et al., 2008), the direct payments of the CAP play an important role in supporting the viability of farming in the EU. However, it is particularly the subsistence and semi-subsistence farms making up such a large proportion of holdings in the NMS that benefit the least from this subsidy and therefore are most likely to be forced towards abandonment or intensification. Whilst it was known prior to accession that many of the smallest holdings in the NMS would have to be excluded from direct payments due to the administrative costs, this system was nonetheless adopted unaltered, exacerbating the competitive disadvantage of semi-subsistence farms (Swain, 2013). Furthermore, few of the rural development measures so far offered by the CAP are accessible by semi-subsistence farms as they are either too small or lack the financial capital required (Davidova et al., 2012; there is, however, a planned single payment in the 2014-2020 CAP for "small farms", which may improve the financial situation of these holdings (Hennessy, 2014). Nevertheless, it seems to have generally been the fate of NMS thus far to have "imported" EU policies that have been designed according to the priorities of the EU-15, without being able to "upload" those with a better fit to their own structures and institutions (Gorton et al., 2009; Davidova et al., 2012; Swain, 2013).

This situation is also found in other rural development measures, such as agri-environment schemes (AES). AES are the only instrument in the CAP directly targeting farmland biodiversity conservation, and in 2009, $20.9 \%$ of farmland in the EU was enrolled in AES (Eurostat, 2012), which received approximately $€ 27.8$ billion in AES support over the period 2007-2012 (ENRD, 2013). Although member states have a high degree of flexibility in the design and implementation of AES (EC, 2005), several schemes in the NMS are based on well-supported data from Northern and Western Europe that may not fit to the local or regional circumstances. For example, postponing mowing from spring to late summer is a popular agri-environment measure found in a review of several Western European studies to be generally beneficial for plant and invertebrate diversity (Humbert et al., 2012; Buri et al., 2013, 2014). However, when applied to extensively managed patches of meadow such as exist in many regions of Romania, the result is a synchronization of mowing leading to potentially harmful homogenization of management (Dahlström et al., 2013; see also Konvička et al., 2007 and Cizek et al., 2011). 
In contrast to much of lowland EU, the main challenge - and opportunity - for farmland biodiversity conservation in the NMS is that a large number species of conservation concern often still co-exist (e.g. in Polish field margins: Wuczyński et al., 2014). These target species may have different requirements, creating conflicts when prescribing management measures. Simple but rigid measures applied over large areas can therefore be worse than existing management (e.g. Nikolov et al., 2011; Elts \& Lõhmus, 2012). Another side effect of rigid prescriptions is the disruption and eventual loss among local people of traditional ecological knowledge related to adaptive management (Babai \& Molnár, 2014).

Many areas of HNV farmland in Central and Eastern Europe are also not eligible for AES support. As with the direct payments, a large proportion of holdings fall below the size threshold, or the vegetation does not fall into one of the categories of agricultural land defined by the EU (Kazakova \& Stefanova, 2011; Elts \& Lõhmus, 2012). Actively harnessing the biodiversity value of this farmland will therefore require adapting measures to regional circumstances, and allowing for variable or even idiosyncratic small-scale management using a more flexible understanding of farmland habitats. For this to happen, interdisciplinary research is needed into the impact of different policy options on ecology and economy of the regions.

\section{Conclusion}

The maintenance of HNV farmland is a policy priority for the EU, not only for the ecological, cultural and economic benefits it provides, but also for the conservation of many "wild" species that over millennia of human disturbance have come to rely on these habitats. Thus, whilst there are many areas in which the promotion of low-intensity agriculture is now clearly inappropriate, the continuation of these practices should be made viable for local land managers in places where it still exists. Direct market incentives to sustainably support lowintensity farming practices are currently generally lacking (Fischer et al., 2012), therefore the viability of HNV farmland is largely influenced by payments through the EU CAP.

We have argued that the currently generally lower level of agricultural intensification in Central and Eastern European countries is accompanied by relatively high species richness and rare and specialized species. This makes them of special conservation significance in the EU, especially given the poor conservation status of farmland relative to other habitat types in Europe (Halada et al., 2011). Nevertheless, the subsistence farms that are often linked HNV 
farmland are currently disadvantaged by the CAP, and their needs are not appropriately addressed by broad and untargeted conservation measures. In addition, little relevant research from this region is entering the international literature, leading to a bias in ecological observations particularly towards Northwest Europe. This not only limits the scalability and transferability of information found in the literature, but also the ability to design locally appropriate conservation measures. Promoting pan-European research and monitoring networks, as well as more research targeted on the farmland of Central and Eastern Europe, both within and outside of the EU, would therefore help to formulate better conservation approaches to counteract the increasing pressure on farmland species increases in Europe.

\section{Acknowledgements}

The authors would like to thank the Volkswagen Foundation for funding the workshop "East meets West - transferring conservation approaches between Eastern and Western European landscapes" (http://eastwest2013.wordpress.com/). We are very grateful to Gwyn Jones, Inge Paulini, Miroslava Čierna-Plassmann and Ana Štrbenac for helpful discussion.

\section{References}

Andrey A., Humbert J.-Y., Pernollet C., \& Arlettaz R. (2014) Experimental evidence for the immediate impact of fertilization and irrigation upon the plant and invertebrate communities of mountain grasslands. Ecology and Evolution, in press.

Aunins A. \& Priednieks J. (2009) Recent changes in agricultural landscape and bird populations in Latvia: impacts and prospects of EU agricultural policy. Avocetta, 33, 9398.

Babai D. \& Molnár Z. (2014) Small-scale traditional management of highly species-rich grasslands in the Carpathians. Agriculture, Ecosystems \& Environment, 182, 123-130.

Báldi A. \& Batáry P. (2011) Spatial heterogeneity and farmland birds: different perspectives in Western and Eastern Europe. Ibis, 153, 875-876.

Báldi A. \& Faragó S. (2007) Long-term changes of farmland game populations in a postsocialist country (Hungary). Agriculture, Ecosystems \& Environment, 118, 307-311.

Batáry P., Báldi A., Sárospataki M., Kohler F., Verhulst J., Knop E., Herzog F., \& Kleijn D. (2010) Effect of conservation management on bees and insect-pollinated grassland plant communities in three European countries. Agriculture, Ecosystems \& Environment, 136, $35-39$. 
Bignal E.M. (1998) Low-intensity livestock systems - defining ecological attributes. Paper presented at The European Policy Evaluation Network (ELPEN), Institute of Mountain and Rural Economics, Greece.

Bignal E.M. \& McCracken D.I. (1996) Low-intensity farming systems in the conservation of the countryside. Journal of Applied Ecology, 33, 413-424.

Buri P., Arlettaz R., \& Humbert J. (2013) Delaying mowing and leaving uncut refuges boosts orthopterans in extensively managed meadows: Evidence drawn from field-scale experimentation. Agriculture, Ecosystems \& Environment, 181, 22-30.

Buri P., Humbert J.-Y., \& Arlettaz R. (2014) Promoting pollinating insects in intensive agricultural matrices: field-scale experimental manipulation of hay-meadow mowing regimes and its effects on bees. PloS one, 9, e85635.

Carvalheiro L.G., Kunin W.E., Keil P., Aguirre-Gutiérrez J., Ellis W.N., Fox R., Groom Q., Hennekens S., Van Landuyt W., Maes D., Van de Meutter F., Michez D., Rasmont P., Ode B., Potts S.G., Reemer M., Roberts S.P.M., Schaminée J., Wallis De Vries M.F., \& Biesmeijer J.C. (2013) Species richness declines and biotic homogenisation have slowed down for NW-European pollinators and plants. Ecology Letters, 16, 870-878.

Cizek O., Zamecnik J., Tropek R., Kocarek P., \& Konvicka M. (2011) Diversification of mowing regime increases arthropods diversity in species-poor cultural hay meadows. Journal of Insect Conservation, 16, 215-226.

Csáki C. \& Jámbor A. (2013) The impact of EU accession: lessons from the agriculture of the new member states. Post-Communist Economies, 25, 325-342.

Dahlström A., Iuga A.-M., \& Lennartsson T. (2013) Managing biodiversity rich hay meadows in the EU: a comparison of Swedish and Romanian grasslands. Environmental Conservation, 40, 194-205.

Davidova S., Bailey A., Dwyer J., Erjavec E., Gorton M., \& Thomson K. (2013) Semisubsistence farming: value and directions of development. Directorate General for Internal Policies. Policy Department B: Structural and Cohesion Policies, Brussels.

Davidova S., Fredriksson L., Gorton M., Mishev P., \& Petrovici D. (2012) Subsistence farming, incomes, and agricultural livelihoods in the new member states of the European Union. Environment and Planning C: Government and Policy, 30, 209-227.

Dicks L. V., Hodge I., Randall N.P., Scharlemann J.P.W., Siriwardena G.M., Smith H.G., Smith R.K., \& Sutherland W.J. (2013) A transparent process for "evidence-informed" policy making. Conservation Letters, 7, 119-125.

Donald P.F., Green R.E., \& Heath M.F. (2001) Agricultural intensification and the collapse of Europe's farmland bird populations. Proceedings of the Royal Society B: Biological Sciences, 268, 25-29.

Dullinger S., Essl F., Rabitsch W., Erb K.-H., Gingrich S., Haberl H., Hülber K., Jarosík V., Krausmann F., Kühn I., Pergl J., Pysek P., \& Hulme P.E. (2013) Europe's other debt 
crisis caused by the long legacy of future extinctions. Proceedings of the National Academy of Sciences of the United States of America, 110, 7342-7347.

EC (2005) Agri-environment Measures: Overview on General Principles, Types of Measures, and Application. European Commission, Directorate General for Agriculture and Rural Development, Brussels.

EEA (2004a) High nature value farmland. Characteristics, trends and policy challenges. European Environment Agency, Luxembourg.

EEA (2004b) Agriculture and the environment in the EU accession countries: Implications of applying the EU common agricultural policy. European Environment Agency, Copenhagen.

Elts J. \& Lõhmus A. (2012) What do we lack in agri-environment schemes? The case of farmland birds in Estonia. Agriculture, Ecosystems \& Environment, 156, 89-93.

ENRD (2013) State of the Total Public and EAFRD expenditure per measure. European Network for Rural Development.

Eurostat

Available

at:

http://epp.eurostat.ec.europa.eu/statistics_explained/index.php/Agrienvironmental_indicator_-_commitments\#cite_ref-1.

Farmer M., Cooper T., Swales V., \& Silcock P. (2008) Funding for Farmland Biodiversity in the EU: Gaining Evidence for the EU Budget Review. A report for the RSPB by Institute for European Environmental Policy and Cumulus Consultants.

Fischer J., Hartel T., \& Kuemmerle T. (2012) Conservation policy in traditional farming landscapes. Conservation Letters, 5, 167-175.

Gorton M., Hubbard C., \& Hubbard L. (2009) The Folly of European Union Policy Transfer: Why the Common Agricultural Policy (CAP) Does Not Fit Central and Eastern Europe. Regional Studies, 43, 1305-1317.

Gregory R.D., van Strien A., Voř́íšek P., Meyling A.W.G., Noble D.G., Foppen R.P.B., \& Gibbons D.W. (2005) Developing indicators for European birds. Philosophical Transactions of the Royal Society B: Biological Sciences, 360, 269-288.

Halada L., Evans D., Romão C., \& Petersen J.-E. (2011) Which habitats of European importance depend on agricultural practices? Biodiversity and Conservation, 20, 23652378.

Hartvigsen M. (2014) Land Use Policy Land reform and land fragmentation in Central and Eastern Europe. Land Use Policy, 36, 330-341.

HCSO (2012) Indicators of sustainable development for Hungary 2012. Hungarian Central Statistical Office, Budapest. 
Hennessy T. (2014) CAP 2014-2020 Tools to enhance family farming: opportunities and limits. Directorate-General for Internal Policies. Policy Department B: Structural and Cohesion Policies - Agriculture, Brussels.

Hristov I. (2011) State of common birds in Bulgaria 2005-2010. Bulgarian Society for the Protection of Birds / BirdLife Bulgaria, Sofia.

Humbert J.-Y., Pellet J., Buri P., \& Arlettaz R. (2012) Does delaying the first mowing date benefit biodiversity in meadowland? Environmental Evidence, 1, 9.

Kamp J., Urazaliev R., Donald P.F., \& Hölzel N. (2011) Post-Soviet agricultural change predicts future declines after recent recovery in Eurasian steppe bird populations. Biological Conservation, 144, 2607-2614.

Kazakova Y. \& Stefanova V. (2011) High Nature Value Farming in South-Eastern Europe: Policy Opportunities and Challenges in the EU Accession. European Forum on Nature Conservation and Pastoralism.

Keišs O. (2003) Recent increases in numbers and the future of Corncrake Crex crex in Latvia. Ornis Hungarica, 12-13, 151-156.

Kleijn D., Kohler F., Báldi A., Batáry P., Concepción E.D., Clough Y., Díaz M., Gabriel D., Holzschuh A., Knop E., Kovács A., Marshall E.J.P., Tscharntke T., \& Verhulst J. (2009) On the relationship between farmland biodiversity and land-use intensity in Europe. Proceedings of the Royal Society B: Biological Sciences, 276, 903-909.

Konvička M., Benes J., Cizek O., Kopecek F., Konvička O., \& Vitaz L. (2007) How too much care kills species: Grassland reserves, agri-environmental schemes and extinction of Colias myrmidone (Lepidoptera: Pieridae) from its former stronghold. Journal of Insect Conservation, 12, 519-525.

Kuussaari M., Bommarco R., Heikkinen R.K., Helm A., Krauss J., Lindborg R., Ockinger E., Pärtel M., Pino J., Rodà F., Stefanescu C., Teder T., Zobel M., \& Steffan-Dewenter I. (2009) Extinction debt: a challenge for biodiversity conservation. Trends in Ecology \& Evolution, 24, 564-71.

Liira J., Aavik T., Parrest O., \& Zobel M. (2008) Agricultural Sector, Rural Environment and Biodiversity in the Central and Eastern European EU Member States. AGD Landscape \& Environment, 2, 46-64.

Mueller N.D., Gerber J.S., Johnston M., Ray D.K., Ramankutty N., \& Foley J. a (2012) Closing yield gaps through nutrient and water management. Nature, 490, 254-7.

Nikolov S.C., Demerdzhiev D.A., Popgeorgiev G.S., \& Plachiyski D.G. (2011) Bird community patterns in sub-Mediterranean pastures: the effects of shrub cover and grazing intensity. Animal Biodiversity and Conservation, 34, 11-21.

Perkins A.J., Maggs H.E., Watson A., \& Wilson J.D. (2011) Adaptive management and targeting of agri-environment schemes does benefit biodiversity: a case study of the corn bunting Emberiza calandra. Journal of Applied Ecology, 48, 514-522. 
Rego P., Guitián M., Castro H., Costa J., \& Sobrino C. (2013) Loss of European Dry Heaths in NW Spain: A Case Study. Diversity, 5, 557-580.

Reidsma P., Tekelenburg T., Vandenberg M., \& Alkemade R. (2006) Impacts of land-use change on biodiversity: An assessment of agricultural biodiversity in the European Union. Agriculture, Ecosystems \& Environment, 114, 86-102.

Rotter A. \& Gostincar C. (2014) A defense of Eastern European science. Science, 343, 839.

Sanderson F.J., Kucharz M., Jobda M., \& Donald P.F. (2013) Impacts of agricultural intensification and abandonment on farmland birds in Poland following EU accession. Agriculture, Ecosystems \& Environment, 168, 16-24.

Stoate C., Báldi A., Beja P., Boatman N.D., Herzon I., van Doorn A., de Snoo G.R., Rakosy L., \& Ramwell C. (2009) Ecological impacts of early 21st century agricultural change in Europe - A review. Journal of Environmental Management, 91, 22-46.

Storkey J., Meyer S., Still K.S., \& Leuschner C. (2012) The impact of agricultural intensification and land-use change on the European arable flora. Proceedings of the Royal Society B: Biological Sciences, 279, 1421-1429.

Van Swaay C. \& Warren M. (2012) Developing butterflies as indicators in Europe: current situation and future options. De Vlinderstichting/Dutch Butterfly Conservation, Butterfly Conservation UK, Butterfly Conservation Europe, Wageningen, reportnr. VS2012.012.

Swain N. (2013) Agriculture "East of the Elbe" and the Common Agricultural Policy. Sociologia Ruralis, 53, 369-389.

Szymkowiak J., Skierczyński M., \& Kuczyński L. (2014) Are buntings good indicators of agricultural intensity? Agriculture, Ecosystems \& Environment, 188, 192-197.

Tryjanowski P., Hartel T., Báldi A., Szymański P., Tobolka M., Herzon I., Goławski A., Konvička M., Hromada M., Jerzak L., Kujawa K., Lenda M., Orłowski G., Panek M., Skórka P., Sparks T.H., Tworek S., Wuczyński A., \& Żmihorski M. (2011) Conservation of Farmland Birds Faces Different Challenges in Western and Central-Eastern Europe. Acta Ornithologica, 46, 1-12.

Tscharntke T., Klein A.M., Kruess A., Steffan-Dewenter I., \& Thies C. (2005) Landscape perspectives on agricultural intensification and biodiversity - ecosystem service management. Ecology Letters, 8, 857-874.

Uthes S. \& Matzdorf B. (2013) Studies on Agri-environmental Measures: A Survey of the Literature. Environmental Management, 51, 251-266.

Verhulst J., Báldi A., \& Kleijn D. (2004) Relationship between land-use intensity and species richness and abundance of birds in Hungary. Agriculture, Ecosystems \& Environment, 104, 465-473.

Voříšek P., Jiguet F., van Strien A.J., Škorpilová J., Klvaňová A., \& Gregory R.D. (2010) Trends in abundance and biomass of widespread European farmland birds: how much have we lost? BOU Proceedings - Lowland Farmland Birds III. 
Wuczyński A., Dajdok Z., Wierzcholska S., \& Kujawa K. (2014) Applying red lists to the evaluation of agricultural habitat: regular occurrence of threatened birds, vascular plants, and bryophytes in field margins of Poland. Biodiversity and Conservation, 23, 9991017.

Young J., Richards C., Fischer A., Halada L., Kull T., Kuzniar A., Tartes U., Uzunov Y., \& Watt A. (2007) Conflicts between Biodiversity Conservation and Human Activities in the Central and Eastern European Countries. Ambio, 36, 545-550.

\section{Supplementary material}

Appendix S1: Web of Science search protocol and results

Search of the Web of Science on 10.01.2014 (without social sciences), using the search terms Topic $=($ agricult* OR farmland) AND Topic=(biodiversity OR "species richness").

Timespan=All years. Databases=SCI-EXPANDED. The results were refined to the research areas "Ecology", "Environmental Sciences", and "Biodiversity Conservation", yielding 4,717 publications. Publication records were downloaded to an Excel spreadsheet, and assigned a country where the research took place (or multiple countries, in the case of international studies), and country of first author. All studies not taking place in the EU, Norway or Switzerland were excluded. Theoretical papers without data from a stated country were excluded, as were papers using global data, literature reviews unless explicitly stated which countries were covered, and all other papers in which the location was not stated in the title or abstract. This left 1952 publications. For papers using data from multiple countries, these were treated as separate studies, yielding 2007 records (assigned to country in S. Table 1). 
Table S1: Results of a Web of Science search on 10.01.2014. UAA = Utilized Agricultural Area, from faostat.fao.org.

\begin{tabular}{|c|c|c|c|c|c|c|}
\hline & Country & $\begin{array}{l}\text { Country of } \\
\text { research (incl. } \\
\text { multiple } \\
\text { records) }\end{array}$ & $\begin{array}{l}\text { Country } \\
\text { 1st author }\end{array}$ & $\begin{array}{c}\text { Average UAA x } 1000 \\
\text { ha over period 1991- } \\
2011 \text { (where data } \\
\text { available) }\end{array}$ & $\begin{array}{c}\text { Studies } \\
\text { per } 100 \\
000 \text { ha } \\
\text { UAA }\end{array}$ & $\begin{array}{c}1 \text { st authors } \\
\text { per } 100000 \\
\text { ha UAA }\end{array}$ \\
\hline AT & Austria & 31 & 31 & 3328.476 & 0.931 & 0.931 \\
\hline $\mathrm{BE}$ & Belgium & 37 & 41 & 1377.167 & 2.687 & 2.977 \\
\hline BG & Bulgaria & 4 & 4 & 5586.810 & 0.072 & 0.072 \\
\hline $\mathrm{CH}$ & Switzerland & 125 & 120 & 1563.595 & 7.994 & 7.675 \\
\hline $\mathrm{CY}$ & Cyprus & 0 & 0 & 144.71 & 0 & 0 \\
\hline $\mathrm{CZ}$ & $\begin{array}{c}\text { Czech } \\
\text { Republic }\end{array}$ & 36 & 32 & 4265.526 & 0.844 & 0.750 \\
\hline $\mathrm{DE}$ & Germany & 238 & 252 & 17063.095 & 1.395 & 1.477 \\
\hline DK & Denmark & 41 & 38 & 2685.333 & 1.527 & 1.415 \\
\hline $\mathrm{EE}$ & Estonia & 29 & 23 & 972.900 & 2.981 & 2.364 \\
\hline FI & Finland & 70 & 70 & 2296.238 & 3.048 & 3.048 \\
\hline FR & France & 191 & 171 & 29733.667 & 0.642 & 0.575 \\
\hline GR & Greece & 25 & 23 & 8071.281 & 0.310 & 0.285 \\
\hline HR & Croatia & 1 & 0 & 1603.380 & 0.062 & 0.000 \\
\hline $\mathrm{HU}$ & Hungary & 39 & 32 & 5943.524 & 0.656 & 0.538 \\
\hline IE & Ireland & 50 & 48 & 4374.481 & 1.143 & 1.097 \\
\hline IT & Italy & 95 & 92 & 15089.124 & 0.630 & 0.610 \\
\hline LT & Lithuania & 9 & 4 & 3030.710 & 0.297 & 0.132 \\
\hline LU & Luxembourg & 3 & 1 & 129.395 & 2.318 & 0.773 \\
\hline LV & Latvia & 6 & 1 & 1856.150 & 0.323 & 0.054 \\
\hline MT & Malta & 0 & 0 & 10.4 & 0 & 0 \\
\hline NL & Netherlands & 117 & 127 & 1948.443 & 6.005 & 6.518 \\
\hline NO & Norway & 28 & 23 & 1038.032 & 2.697 & 2.216 \\
\hline PL & Poland & 56 & 44 & 17268.619 & 0.324 & 0.255 \\
\hline PT & Portugal & 41 & 39 & 3795.776 & 1.080 & 1.027 \\
\hline RO & Romania & 12 & 7 & 14463.286 & 0.083 & 0.048 \\
\hline $\mathrm{SE}$ & Sweden & 126 & 123 & 3205.952 & 3.930 & 3.837 \\
\hline SK & Slovakia & 17 & 13 & 2198.232 & 0.773 & 0.591 \\
\hline SL & Slovenia & 8 & 7 & 507.790 & 1.575 & 1.379 \\
\hline SP & Spain & 169 & 154 & 29258.107 & 0.578 & 0.526 \\
\hline UK & $\begin{array}{c}\text { United } \\
\text { Kingdom }\end{array}$ & 403 & 429 & 17385.190 & 2.318 & 2.468 \\
\hline
\end{tabular}




\section{Chapter 6}

Synopsis

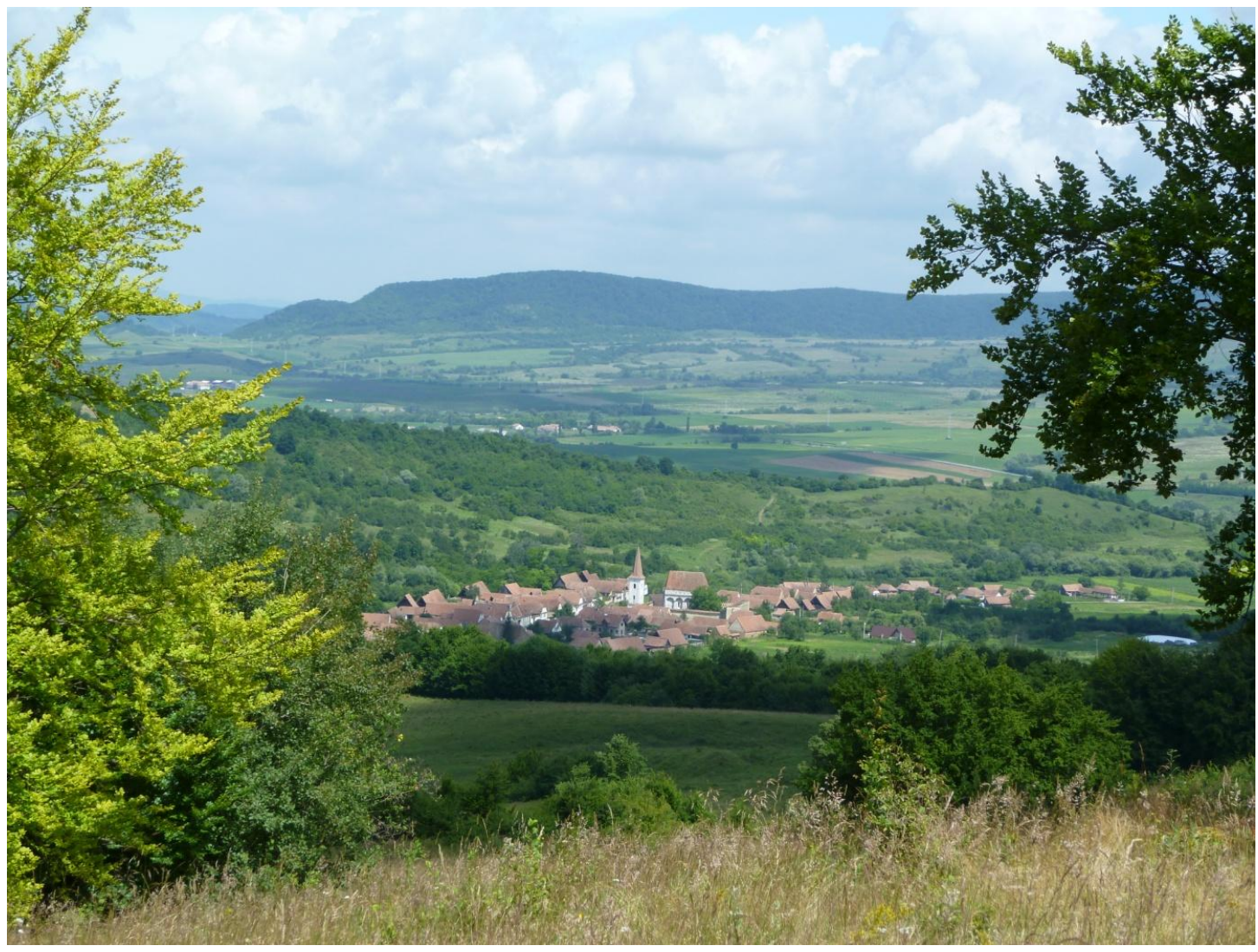




\section{Central messages}

The preceding chapters have discussed a range of important factors affecting the conservation of semi-natural grasslands in Southern Transylvania. They have examined the issue at different scales (local, landscape, and international), and from different perspectives (grassland ecology, institutional governance, and conservation research and policy), demonstrating the complexity of promoting sustainable use of semi-natural grasslands that benefits both biodiversity and the people that use them. In the following, four messages are synthesised from the findings, drawing conclusions for conservation research, policy and practice. 
i) Local and landscape effects play similarly significant roles in the species-richness of both sessile (plants) and mobile (Orthoptera) taxonomic groups in the study region, potentially through their influence on the species pool for plants and the amount of habitat for Orthoptera.

Chapter 2 found that, under low-intensity management, the richness of the taxonomic and functional groups investigated was best explained by a combination of local (plot scale) and landscape factors (within a $2 \mathrm{~km}$ radius). For plants, this was mainly landscape heterogeneity, i.e. the richness and evenness of surrounding land cover types, and soil nitrogen content. For Orthoptera, this was mainly grassland area and local vegetation height.

The positive effect of landscape heterogeneity on plant species richness was significant for characteristic plant species, which form the core of dry and mesophilic grassland communities in the region, but not for non-characteristic plants. However, there were no differences between insect vs. non-insect pollinated species or heavy vs. light seeded species in this respect, and landscape heterogeneity did not significantly affect community composition. This supports the idea that a variety of (semi-natural) habitat types provide refuges, even for typical grassland species. Landscape heterogeneity may thus promote frequent spill-over to sustain small populations, or for recolonization after disturbance, through a rich species pool (Tscharntke et al. 2012).

Orthoptera species richness and abundance did not react to landscape heterogeneity, but did increase with proportion of grassland in the landscape. This suggests that habitat amount is important for this group irrespective of its configuration (Fahrig 2013), perhaps because the relatively high mobility of Orthoptera permits easy movement between patches.

The highly significant effects of landscape factors demonstrate that conservation measures in species-rich grassland should target landscape, as well as local scale processes in order to promote species richness. However, the two taxonomic groups were sensitive to different factors, and, contrary to many previous studies (e.g. Marini et al. 2008; Kovács-Hostyánszki et al. 2011; Kati et al. 2012), weakly negatively correlated. Conservation approaches in the study area should therefore aim to promote a range of low-intensity land use practices in order to support a variety of landscape types. This is particularly important in eastern European countries such as Romania, where many such species-rich landscapes still exist but are threatened by agricultural intensification and abandonment (Liira et al. 2008). 
ii) There has been an increasing de facto privatization of common pastures in recent years through the renting of parcels to individuals, resulting in greater inequality between users. This has been driven largely by the existence of area-based EU subsidies since 2007, together with the failure of smallholders to act collectively e.g. in farmer associations.

Chapter 3 concludes that, although the legal rights of local livestock owners to use the common pastures in the study region are likely to remain, in practice pastures are increasingly being divided into parcels, which are rented to individuals for their sole use. This contrasts with their traditional use, in which the pastures were grazed by village herds consisting of cattle from multiple smallholders.

Renting parcels for sole use has increased dramatically in response to the area-based subsidies (direct payments and agri-environment scheme payments of the Common Agricultural Policy - CAP). This requires applicants to have a contract in their name for a minimum period of 5 years (for agri-environment payments), entitling them to subsidies of up to around $€ 270 / \mathrm{ha} / \mathrm{yr}$ - a sum equivalent to an average Romanian monthly wage, and thus a large incentive. With the rental system, individuals with more animals and influence tend to get priority when parcels are being assigned, increasing inequality between users and in some cases denying livestock owners with only few animals access to the pasture. Sole use of rented areas also potentially increases the threat of overgrazing or intensification, as such decisions can be made more easily by individuals than by groups of users, and these areas are no longer monitored by other members of the community.

Associations of farmers can also rent land and apply for subsidies on their members' behalf. This money can be spent on collective projects, whilst retaining the common use of the pasture. Associations could also help improve dissemination of information for farmers, and provide a powerful way of implementing conservation measures such as agri-environment schemes at large scale. Many associations have been formed in the study region, however, most currently do not function due to lack of willingness to participate and lack of organization. 
iii) The commons institutions are challenged by opportunistic behaviour, rapid changes to which they must constantly adapt, and increasing heterogeneity of members. Farmer associations offer an opportunity to exploit options for sustainable use of common pastures, but require support and training.

The study region contains over 3000 ha of wood-pastures (approximately $7 \%$ of all grassland), the majority of which, as is generally the case for pastures in this area, are managed in common. A breakdown in commons governance may have particularly severe and irreversible consequences in these valuable habitats, such as the felling of ancient trees. Current barriers to effective governance based on Ostrom (1994) and identified in the interviews include: rapid and ongoing changes, for example in the local population, and in national agricultural policy; increases in the heterogeneity of participants, especially in the scale of their farming; and corruption and other forms of opportunistic behaviour, encouraged by the subsidy money available.

Although not all of these issues can be directly addressed within the current system, one option is to improve the robustness and capacity of farmer associations. These could effectively take over the commons governance from the Town Halls, which traditionally oversaw the use of the pastures, but now are no longer adapted to the needs of the farmers. Such associations could also play a big role in disseminating information (for example about production methods or new legislation), as well as helping their members to market goods and apply for subsidies. This could steer the use of common pastures towards sustainable use by increasing their economic viability, for example through agri-environment subsidies, marketing of high-end goods such as organic products, and economies of scale.

For these reasons, farmer associations are already a priority target for Romanian agricultural policy and are eligible for financial support under several measures of the current, as well as post-2014, CAP (Luca \& Toderiţă 2012). Uptake of these funds is, however, extremely low, partly due to barriers at the policy level such as overly complicated bureaucratic requirements (Luca \& Toderiţă 2012), but also in the study region due to lack of knowledge and trust at the local level preventing associations from forming in the first place. Guidance and training for associations from governmental organizations, regional networks or NGOs could help increase transparency and trust, and reduce fear of corruption among members. This could be funded through better use of the information and training measures provided for under the CAP. 
iv) Bias in the international literature needs to be reduced by generating more research from less intensive agricultural landscapes, especially in the east. This evidence needs to inform locally appropriate agri-environment schemes for both east and west, but which are accompanied by adequate educational and training elements.

Chapter 5 argues that stark differences are apparent between the context for farmland conservation between east and west Europe. While the local ecological, cultural and political situation is obvious to those working on the ground, for international researchers and EU (or even national) policy makers, it is easily overlooked that, for example, the same conservation measure may not have the same effect in the two regions. In particular, there is a bias in the international literature towards western farmland ecosystems, and little information about much of the less intensified farmland of the east.

Publication of data from the less well studied areas of Europe should therefore be encouraged, especially through pan-European studies. Greater recognition of regional differences will not only help to enrich ecological understanding through the comparison of different systems, but also provide evidence-based and locally appropriate conservation approaches. In intensified areas in the west this may mean dedicated protection and management for target farmland species. In the east, however, large areas of existing species-rich farmland also provide an opportunity to integrate production and conservation of functioning ecosystems at a landscape scale. In this context, conservation is not freezing management in time, but encouraging sustainable use that maintains the species-rich character of these habitats as far as possible, whilst allowing land use to adapt to the needs of the local populations. This entails not only financial incentives, but better means of recognizing benefits from low-intensity farming, such as through better understanding of ecosystem services, as well as through education to sensitise farmers and communities to agricultural biodiversity. 


\section{References}

Fahrig, L. (2013) Rethinking patch size and isolation effects: the habitat amount hypothesis. Journal of Biogeography, 40, 1649-1663.

Kati, V., Zografou, K., Tzirkalli, E., Chitos, T. \& Willemse, L. (2012) Butterfly and grasshopper diversity patterns in humid Mediterranean grasslands: the roles of disturbance and environmental factors. Journal of Insect Conservation, 16, 807-818.

Kovács-Hostyánszki, A., Kőrösi, Á., Orci, K.M., Batáry, P. \& Báldi, A. (2011) Set-aside promotes insect and plant diversity in a Central European country. Agriculture, Ecosystems \& Environment, 141, 296-301.

Liira, J., Aavik, T., Parrest, O. \& Zobel, M. (2008) Agricultural Sector, Rural Environment and Biodiversity in the Central and Eastern European EU Member States. AGD Landscape \& Environment, 2, 46-64.

Luca, L. \& Toderiţă, A. (2012) Why Isn't Agricultural Association Attractive? Romanian Center for European Policies (CRPE Policy Brief nr. 14), Bucharest.

Marini, L., Fontana, P., Scotton, M. \& Klimek, S. (2008) Vascular plant and Orthoptera diversity in relation to grassland management and landscape composition in the European Alps. Journal of Applied Ecology, 45, 361-370.

Ostrom, E. (1994) Institutional analysis, design principles and threats to sustainable community governance and management of commons. Community management and common property of coastal fisheries in Asia and the Pacific: concepts, methods and experiences, pp. 34-50. ICLARM Conf. Proc. 45.

Tscharntke, T., Tylianakis, J.M., Rand, T.A., Didham, R.K., Fahrig, L., Batáry, P., Bengtsson, J., Clough, Y., Crist, T.O., Dormann, C.F., Ewers, R.M., Fründ, J., Holt, R.D., Holzschuh, A., Klein, A.M., Kleijn, D., Kremen, C., Landis, D.A., Laurance, W., Lindenmayer, D., Scherber, C., Sodhi, N.S., Steffan-Dewenter, I., Thies, C., van der Putten, W.H. \& Westphal, C. (2012) Landscape moderation of biodiversity patterns and processes - eight hypotheses. Biological Reviews, 87, 661-685. 


\section{Summary}

Semi-natural grasslands are species-rich habitats of major importance for many taxonomic groups and as a provider of ecosystem services, yet are becoming increasingly rare and thus a conservation priority in Europe. The loss of these habitats is mainly linked to the processes of agricultural intensification and abandonment, and geographically highly variable in Europe. This thesis focuses on the region of Southern Transylvania in Romania, in which almost all grassland is semi-natural, but under increasing threat from changes in farming practices. It considers the conservation of these grasslands at different spatial scales and from multiple perspectives, addressing both the ecological and the social contexts in which management takes place.

Conservation measures are generally applied at the field scale, yet grassland plants and animals frequently interact with populations in surrounding habitats. Chapter 2 therefore investigates the effects of ecological processes at local (plot) and landscape (2 km radius) scales on grassland plants and Orthoptera (grasshoppers, crickets and bush-crickets). The results show that the effects of landscape factors on species richness are similarly strong and significant as those of local factors. However, the two taxonomic groups reacted to different landscape factors: plant species richness increased with landscape heterogeneity, and Orthoptera with proportion of grassland habitat. This suggests that conservation measures for such extensive grasslands must also consider the landscape scale in order to provide effective protection, but no single landscape composition will benefit all groups. Support for smallscale, low-intensity farming practices that retains a variety of landscapes types is therefore likely to provide the greatest overall benefit for grassland diversity.

Alongside design, the success of conservation measures such as agri-environment schemes depends on the ability and willingness of land managers to apply them. In the study area, effective cooperation between land managers is crucial for sustainable management, as most of the grazed grassland in the study area is common land, i.e., most members of the local community have rights to use it. However, the analysis in Chapter 3 finds that this system is now moving increasingly towards a division of the pasture into sole-use parcels rather than used in common, driven mainly by the area-based subsidies available through the EU Common Agricultural Policy. This de facto privatisation of the commons is currently negatively affecting equality of access for users, and is a potential threat to the low-intensity use of the pastures. Chapter 4 therefore investigates the opportunity to target farmer associations as a means to maintain the common use of the pastures whilst adapting to the 
current situation. These could exploit the subsidies available to provide good management for the common grasslands, as well as information and services for farmers, but are currently in need of more training and support.

At the European level, research and policy needs to better acknowledge the diversity of ecological and the human contexts in which conservation in agricultural habitats such as seminatural grassland takes place. Chapter 5 argues that there are significant differences in farmland conservation between countries in the east and those in the west of Europe that are insufficiently recognised. Whilst most research and policy takes a western perspective, Eastern Europe contains large areas of species rich farmland that may require different conservation approaches, due to the differences e.g. in farm structures, in attitudes towards conservation, and in levels of biodiversity. Publication of data from less well-studied areas of Europe should be encouraged, especially through pan-European studies, as well as more evidence-based management and conservation education in order to improve its effectiveness.

The widespread semi-natural grasslands in Southern Transylvania offer an important opportunity to study, and conserve, species-rich ecosystems in low-intensity farmed landscapes. Although seemingly "traditional", change is constant in these landscapes, and these man-made habitats need to adapt to meet the needs of the human population. By understanding the drivers of grassland diversity, as well as the drivers of the management systems that maintain it, this thesis aims to demonstrate ways in which development and biodiversity goals can be integrated, such as more evidence-based and efficient use of conservation schemes, as well as better cooperation between small-scale farmers to exploit marketing opportunities and subsidies for low-intensity farming. This is relevant to many areas of Eastern Europe, where widespread low-intensity farming as well as communal land management provides an opportunity to maintain species rich farmland into the future. 


\section{Zusammenfassung}

Halbnatürliche Grünlandflächen sind artenreiche Habitate von großer Bedeutung für viele Tier- und Pflanzenarten und die Bereitstellung zahlreicher Ökosystemdienstleistungen. Jedoch werden diese Flächen zunehmend seltener, weshalb ihr Schutz in Europa ein wichtiges Ziel geworden ist. Der Verlust von halbnatürlichem Grünland ist häufig mit einer Intensivierung der Agrarwirtschaft verbunden und innerhalb Europas geographisch sehr unterschiedlich. Diese Arbeit befasst sich hauptsächlich mit der Region Südtranssilvanien in Rumänien, in der fast alle dauerhaften Grünlandflächen halbnatürlich sind, jedoch von der zunehmenden Intensivierung bedroht werden. Der Schutz dieser Grünlandflächen wird hier auf unterschiedlichen räumlichen Ebenen und aus unterschiedlichen Blickwinkeln betrachtet, um sowohl die ökologischen als auch die gesellschaftlichen Aspekte der Bewirtschaftung zu berücksichtigen.

Schutzmaßnahmen werden derzeit hauptsächlich auf der Feldebene umgesetzt, jedoch interagieren Grünlandarten häufig auch mit Populationen in der umgebenden Landschaft. Daher beschäftigt sich Kapitel 2 dieser Arbeit am Beispiel von Pflanzen und Heuschrecken mit den Auswirkungen von ökologischen Prozessen auf Grünlandarten auf lokaler und auf Landschaftsebene. Die Ergebnisse zeigen, dass die Landschaftszusammensetzung im 2 kmRadius einen gleichstarken Effekt auf die Artenvielfalt hat wie die lokalen Faktoren. Hierbei steigt der Pflanzenartenreichtum mit höherer Landschaftsheterogenität, während die Heuschrecken positiv auf den Anteil von Grünlandfläche in der Umgebung reagieren. Schutzmaßnahmen für artenreiches Grünland sollten daher Prozesse auf Landschaftsebene mit berücksichtigen, obwohl kein Landschaftstyp gleichzeitig alle Artengruppen begünstigt. Daher ist die Förderung einer extensiven Landwirtschaft die beste Möglichkeit, eine Vielfalt an Landschaftstypen zu erhalten, die die Artenvielfalt der Grünländer unterstützt.

Neben dem Design von Schutzmaßnahmen ist auch ihre Umsetzbarkeit von großer Bedeutung. In der Untersuchungsregion ist die Kooperation der Nutzer miteinander besonders wichtig für Management-Entscheidungen, da es sich bei dem beweideten Grünland überwiegend um gemeinschaftlich benutzte Flächen (Allmendweiden) handelt. Allerdings zeigt Kapitel 3, dass sich dieses System hin zur Aufteilung der Flächen in kleinere Parzellen, die von Einzelnen gepachtet werden, verändert. Diese „Privatisierung“ der Allmende wird hauptsächlich von den flächenbasierten Zahlungen der gemeinsamen EU-Agrarpolitik gefördert. Sie wirkt sich derzeit sowohl negativ auf den Zugang von Kleinbauern zur Weide, als auch möglicherweise auf deren extensive Bewirtschaftung aus. Kapitel 4 untersucht daher 
das Potential von Bauernverbänden für die Wahrung der gemeinschaftlichen Bewirtschaftung von Allmendweiden. Bauernverbände können mithilfe von Agrarsubventionen eine extensive Bewirtschaftung der Allmendweide sichern sowie auch Informationen und Dienstleistungen für die Landwirte bereitstellen. Derzeit bedürfen derartige Verbände in der Untersuchungsregion allerdings noch Unterstützung bei der Organisation ihrer Aktivitäten.

Forschung und Politik auf der europäischen Ebene müssen die Vielfalt der sozioökologischen Kontexte berücksichtigen, unter denen Naturschutz in Agrarlandlandschaften stattfindet. Kapitel 5 zeigt auf, dass die Unterschiede im Naturschutz in der Agrarlandschaft zwischen Ländern in West- und Osteuropa nicht ausreichend wahrgenommen werden. Forschung und Politik sind vorwiegend auf westeuropäische Länder fokussiert, während sich besonders große Flächen von artenreichen Agrarlandschaften jedoch in Osteuropa befinden. Diese benötigen häufig andere Naturschutzkonzepte, da sich die Hofstruktur und die Einstellung gegenüber dem Naturschutz vielfach von der in Westeuropa unterscheiden. Forschung in weniger untersuchten Gegenden sollte gefördert werden, um regionalspezifische, wissensbasierte Maßnahmen zu erarbeiten. Zudem sollte versucht werden, über Umweltbildung die Effektivität von Maßnahmen zu erhöhen.

Die ausgedehnten Grünlandflächen in Südtranssilvanien bieten eine hervorragende Möglichkeit extensive, artenreiche Agrarlandschaften zu untersuchen und zu schützen. Auch wenn die Bewirtschaftung traditionell wirkt, ist der Fortschritt in vielen Bereichen sichtbar. Diese von Menschen geschaffenen Habitate müssen den zukünftigen Bedürfnissen einer wachsenden Bevölkerung angepasst werden. Diese Arbeit versucht durch das Verständnis der Einflussfaktoren auf Grünland, Wege aufzuzeigen, wie Entwicklungs- und Naturschutzziele miteinander verbunden werden können. Dies kann vor allem durch wissensbasierte und effiziente Naturschutzmaßnahmen und durch die Stärkung der Zusammenarbeit unterschiedlicher Interessengruppen erreicht werden. Dies gilt für viele Teile Osteuropas, in denen extensive Landwirtschaft und gemeinschaftliche Landnutzung Möglichkeiten bieten, artenreiche Agrarlandschaften auch in Zukunft zu erhalten. 


\section{List of publications}

\section{Peer reviewed journal publications}

Turtureanu, P.D., Todorova, S., Becker, T., Dolnik, C., Ruprecht, E., Sutcliffe L.M.E., Szabó, A. \& Dengler, J. (in press) Scale- and taxon-dependent biodiversity patterns of dry grassland vegetation in Transylvania (Romania). Agriculture, Ecosystems \& Environment 182,15-24

Sutcliffe L.M.E., Paulini, I., Jones, G., Marggraf, R. \& Page, N. (2013): Pastoral commons use in Romania and the role of the Common Agricultural Policy. International Journal of the Commons 7, 58-72

Batáry P., Sutcliffe L.M.E., Dormann C.F. \& Tscharntke T. (2013) Organic farming favours insect-pollinated over non-insect pollinated forbs in meadows and wheat fields. PLoS One $\mathbf{8}$, e54818. doi:10.1371/journal.pone.0054818

Ashford O.S., Foster W.A., Turner B.L., Sayer E.J,. Sutcliffe L.M.E. \& Tanner E.V.J. (2013) Litter manipulation and the soil arthropod community in a lowland tropical rainforest. Soil Biology \& Biochemistry 62, 5-12

Dengler, J., Becker, T., Ruprecht, E., Szabó, A., Becker, U., Beldean, M., Bita-Nicolae, C., Dolnik, C., Goia, I., Peyrat, J., Sutcliffe L.M.E., Turtureanu, P.D. \& Uğurlu, E.: (2012) Festuco-Brometea communities of the Transylvanian Plateau (Romania) - a preliminary overview on syntaxonomy, ecology, and biodiversity. Tuexenia 32, 319-359

Sutcliffe L.M.E. \& Larkham K.S. (2010) High Nature Value grassland assessment in Transylvania: management, monitoring and indicator species. Aspects of Applied Biology 100, 43-50.

Sayer E.J., Sutcliffe L.M.E., Ross, R.I.C. \& Tanner E.V.J. (2009) Arthropod abundance and diversity in a lowland tropical forest floor: the role of habitat space vs. nutrient concentrations. Biotropica 42, 194-200

Marr SM, Sutcliffe L.M.E., Day J.A., Griffiths C.L. \& Skelton P.H. (2009) Conserving the fishes of the Twee River, Cederberg: revisiting the issues. African Journal of Aquatic Science 34, 77-85. 


\section{Other publications}

Sutcliffe L.M.E., Öllerer K., Roellig M. \& Hartel T. (2014) Wood pasture management in Southern Transylvania (Romania): from communal to where? European wood pastures in transition: a social-ecological approach (eds T. Hartel \& T. Plieninger). Routledge, Abingdon, UK.

Sutcliffe L.M.E., Roellig M. \& Hartel T. (2013) An analysis of local institutions governing common pasture use for biodiversity and society. Conference Proceedings of Biodiversity and Society: Societal dimensions of the conservation and utilization of biological diversity (eds J. Friedrich, A. Halsband, L. Minkmar) pp. 297-302

Akeroyd J.R., Sutcliffe L.M.E., Popa R. \& Page N. (2013) The LIFE project STIPA: Saving Transylvania's important pastoral agro-ecosystems. Conference proceedings "Steppe Habitats of Europe: threats, conservation measures and protection”341-350.

Sutcliffe L.M.E. \& Page N. (2012) STIPA: Saving Transylvania's Important Pastoral AgroEcosystems. Bulletin of the EDGG, 14,11-12. (http://www.edgg.org)

Page N., Popa R., Huband S., Balan A. \& Sutcliffe L.M.E. (2012) Romania. High Nature Value farming in Europe (eds R. Oppermann, G. Beaufoy \& G. Jones), pp. 346-357. Verlag Regionalkultur, Ubstadt, Germany.

Sutcliffe L.M.E.\& Larkham K.S. (2011) Monitoring High Nature Value Grassland in Transylvania, Romania. Mountain hay meadows - hotspots of biodiversity and traditional culture (ed. Barbara Knowles). Society of Biology, London. (http://mountainhaymeadows.eu/online_publication/index.html). 


\section{Acknowledgments}

Many people have provided support and help, without which the creation of this thesis would not have been possible. In particular I would like to thank Christoph Leuschner and Rainer Marggraf for providing me with the opportunity to undertake this $\mathrm{PhD}$, and Thomas Becker for his advice and support throughout. I am very grateful to the Biodiversity and Society $\mathrm{PhD}$ programme, funded by the Lower Saxony Ministry of Science and Culture, and its organisers for financing this project and providing an interesting and enriching programme of studies.

I would not have been able to carry out the fieldwork in Romania without the help of Fundatia ADEPT and its staff, an organization dedicated to the biodiversity and the people of Southern Transylvania, and who gave me a unique insight into nature conservation in the region. Similarly, I would like to also thank all the people in the study area who welcomed me into their homes and offices and answered my questions with patience and generosity.

Finally, I am deeply grateful to my numerous co-authors and collaborators, with whom it was a pleasure and an honour to work, and the many other people who provided input and support (scientific or otherwise!): thank you for being there for me. 


\section{Laura M.E. Sutcliffe}

Date of birth: $\quad$ 8th May 1985

Nationality: British

sutcliffe.laura@gmail.com

\section{Education}

2010-2013 Georg-August University Göttingen, Germany

$\mathrm{PhD}$ studies within the interdisciplinary programme Biodiversity and Society: Conservation, governance and biodiversity of common grasslands in Southern Transylvania (Romania)

2007-2009 Georg-August University Göttingen, Germany

M.Sc. Biological Diversity and Ecology

Thesis: Investigating the use of plant indicator species to monitor High

Nature Value Grassland in Transylvania, Romania

Full scholarship from the German Academic Exchange Service (DAAD)

2003-2006 University of Cambridge, UK

B.A. (Hons) Zoology Part II

Thesis: Investigating the effect of leaf-litter manipulation on tropical rainforest microfaunal communities

2001-2003 Sir John Deane's Sixth Form College, Northwich, UK

A-level

Work experience

2010

2010

2007

2007

2005

UK Government Department for Environment, Food and Rural Affairs (Defra), London, UK: Internship in the Natural Environment Strategic Unit. Natural Capital Initiative (NCI), Oxford, UK: Environmental policy internship.

Thomson Ecology, Cardiff, UK: Field Surveyor

Landcare research, Lincoln, New Zealand / University of Cape Town, South Africa: Field assistant.

Smithsonian Tropical Research Institute, Barro Colorado Island, Panama: Field assistant. 